\title{
WestVirginiaUniversity
}

THE RESEARCH REPOSITORY @ WVU

Graduate Theses, Dissertations, and Problem Reports

2009

\section{Women as classically-trained trumpet players in the United States}

\author{
Robyn Dewey Card \\ West Virginia University
}

Follow this and additional works at: https://researchrepository.wvu.edu/etd

\section{Recommended Citation}

Card, Robyn Dewey, "Women as classically-trained trumpet players in the United States" (2009). Graduate Theses, Dissertations, and Problem Reports. 2891.

https://researchrepository.wvu.edu/etd/2891

This Dissertation is protected by copyright and/or related rights. It has been brought to you by the The Research Repository @ WVU with permission from the rights-holder(s). You are free to use this Dissertation in any way that is permitted by the copyright and related rights legislation that applies to your use. For other uses you must obtain permission from the rights-holder(s) directly, unless additional rights are indicated by a Creative Commons license in the record and/ or on the work itself. This Dissertation has been accepted for inclusion in WVU Graduate Theses, Dissertations, and Problem Reports collection by an authorized administrator of The Research Repository @ WVU.

For more information, please contact researchrepository@mail.wvu.edu. 
Women as Classically-Trained Trumpet Players in the United States

by

Robyn Dewey Card

Research Project submitted to the College of Creative Arts Division of Music at West Virginia University in partial fulfillment of the requirements for the degree of

Doctor of Musical Arts

in

Trumpet Performance

\author{
Approved by: \\ Dr. John Winkler, Committee Chairperson \\ Dr. Martin Ferer \\ Dr. Keith Jackson \\ Dr. Virginia Thompson, Research Advisor \\ Dr. Christopher Wilkinson
}

Morgantown, West Virginia

2009

Keywords: Women and Music, Trumpet, Cornet, Orchestra, Band

Copyright 2009 Robyn Dewey Card 


\section{Abstract \\ Women as Classically-Trained Trumpet Players in the United States}

by

\section{Robyn Dewey Card}

This study identifies women in the United States who were trained in the classical tradition and chose to perform trumpet professionally as their full-time career choice during the period of the mid-nineteenth century to the late twentieth century. Although many classicallytrained female trumpet players have developed successful professional careers in the genres of jazz and commercial music, specific focus for this study is on classical solo and chamber artists, members of full-time professional symphony orchestras, and members of professional bands. It examines the performance opportunities that were available to female trumpeters, the music they performed, and whether or not they encountered particular challenges arising from their attempts to succeed professionally in a discipline mostly dominated by men. Chapter Two (Brass Bands and the Golden Age of Cornet) discusses the opportunities created by the professional band movement, which allowed women to perform as section players and also as featured cornet soloists. Chapter Three (Women's Ensembles and the Transition from Cornet to Trumpet) focuses on the development of the orchestra and the initiative taken by women in creating their own ensembles. Chapter Four (New Opportunities Resulting from World War II) examines the performance opportunities for women created by men leaving their positions to serve in the armed forces. Chapter Five (Women in Major Symphony Orchestras) examines the initial acceptance of female trumpeters into the major professional symphonies. Appendix A is a list of women who obtained positions in symphony orchestras, and Appendix C provides transcripts of interviews with select orchestral and solo performers: Barbara Butler, Joyce Johnson-Hamilton, Susan Slaughter, and Marie Speziale. 


\section{Acknowledgements}

There were quite a few people that contributed to this research project. I would especially like to thank Barbara Butler, Joyce Johnson-Hamilton, Susan Slaughter, and Marie Speziale for not only taking the time to share their experiences and allowing me to include them as part of the document, but for paving the way and providing encouragement to me, and others like me.

Eloise Jenkins provided an excellent model in her document on horn players, and also shared her collection of orchestral rosters with me. Norman Schweikert spent time confirming details regarding female orchestral players. Dr. Jill Sullivan shared some of her research regarding the all-women military bands, and Paul Trescott was helpful in providing information on the female cornetists, and allowed me to use some of the pictures from the collection of his uncle, Glenn Bridges.

Special thanks goes to Dr. Virginia Thompson who served as my research advisor. Her continuous encouragement and support allowed me to see this project through to completion. Thank you to the members of my committee: Dr. John Winkler, Dr. Martin Ferer, Dr. Keith Jackson, and Dr. Christopher Wilkinson. My family and friends were an invaluable part of this

process, providing constant encouragement. 


\section{Dedication}

To my family and friends. I am extremely blessed. 


\section{Table of Contents}

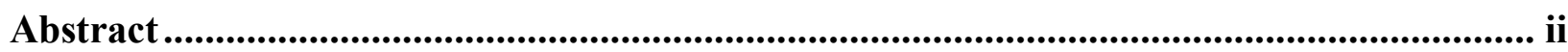

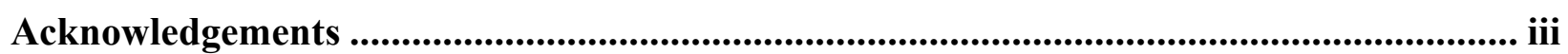

Dedication....................................................................................................................................iv

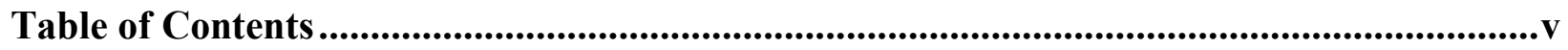

List of Figures ...................................................................................................................................... vii

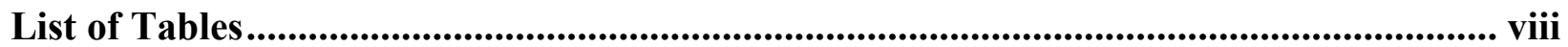

Chapter 1 - Introduction .............................................................................................................1

Chapter 2 - Brass Bands and the Golden Age of Cornet ...............................................................5

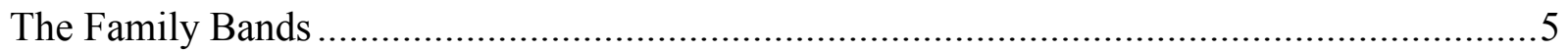

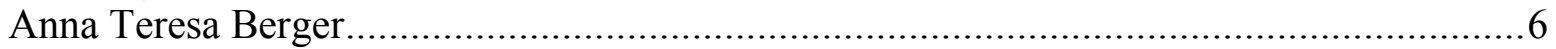

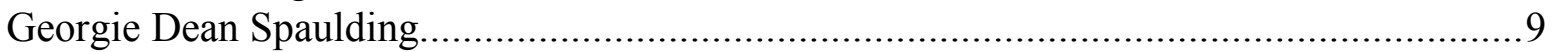

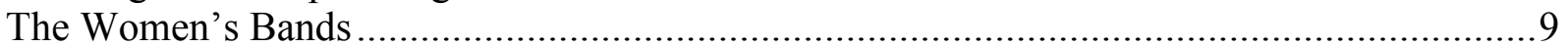

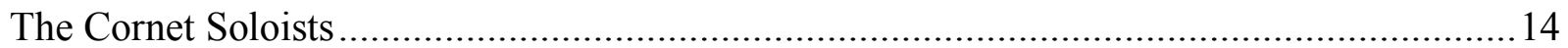

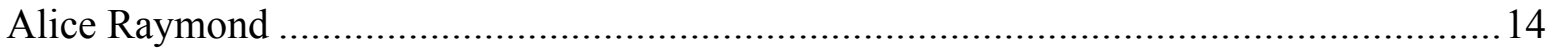

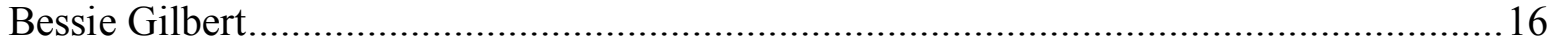

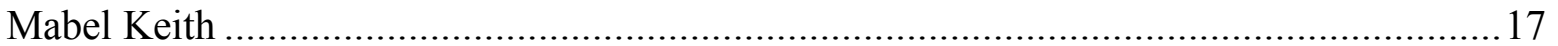

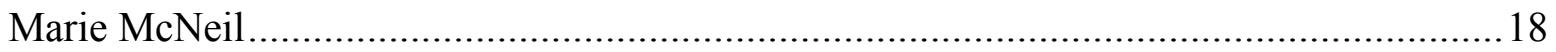

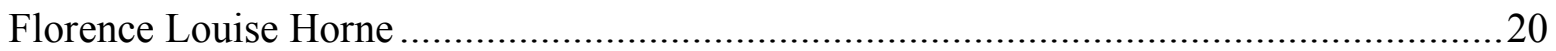

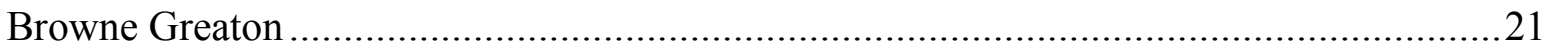

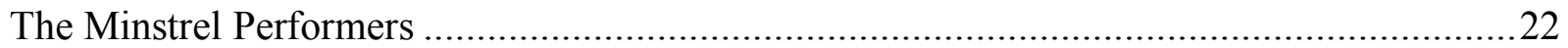

Chapter 3 - Women's Ensembles and the Transition from Cornet to Trumpet...................24

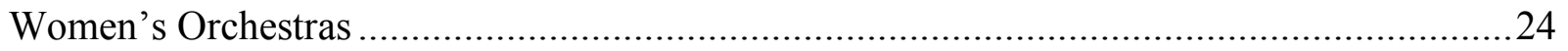

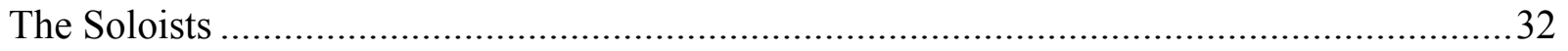

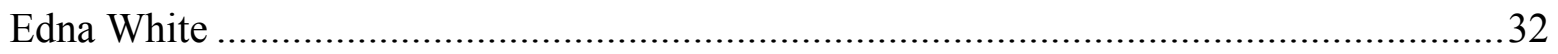

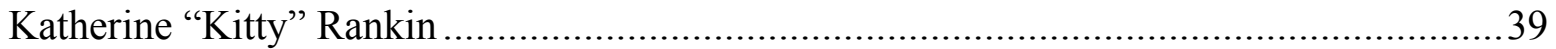

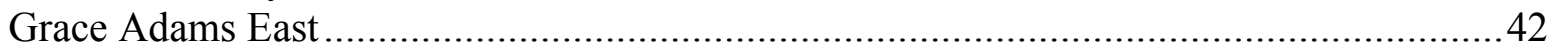

Chapter 4 - New Opportunities Resulting from World War II..................................................45

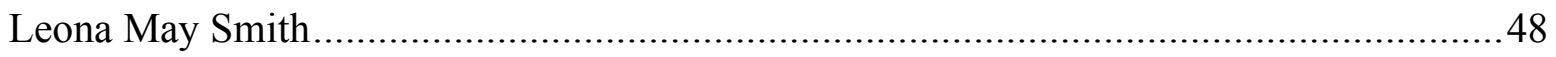

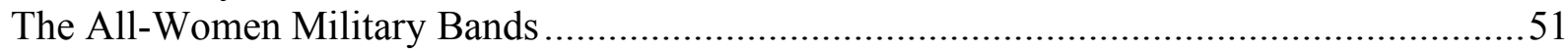

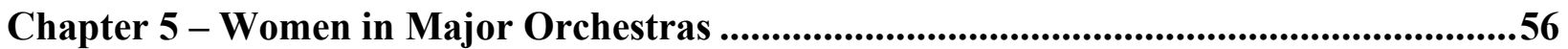

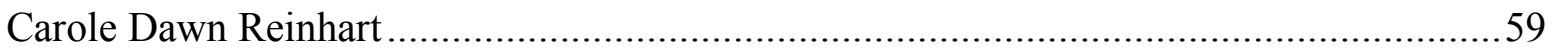

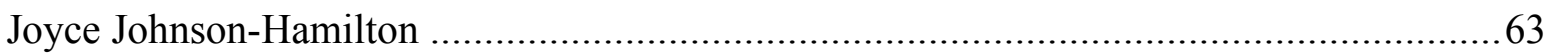

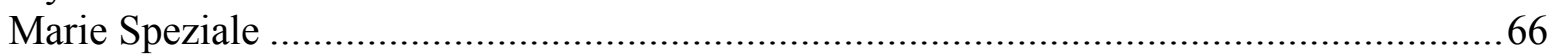

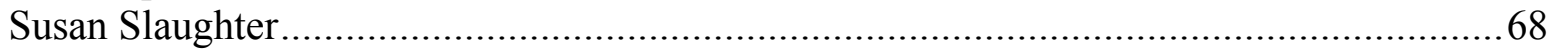

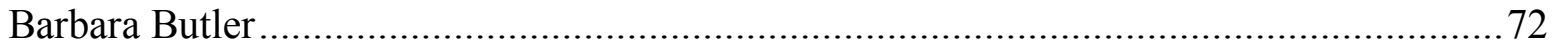

Chapter 6 - Summary, Conclusions, and Recommendations for Further Study ...................74 
Appendix A - Female Trumpeters in Symphony Orchestras ................................................79

Appendix B - West Virginia University Internal Review Board Documentation ................82

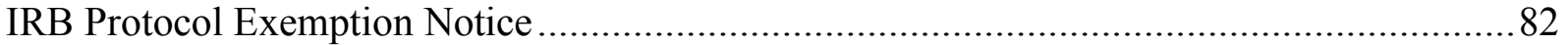

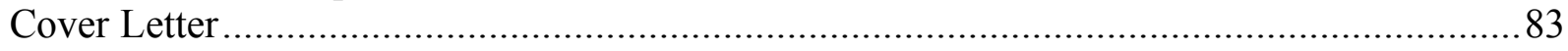

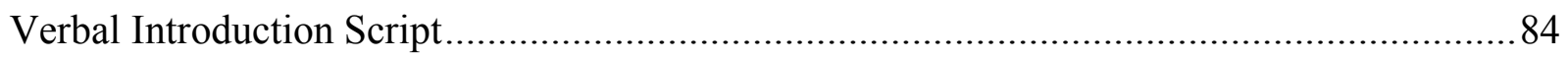

Appendix C - Interviews with Select Female Trumpet Players...........................................85

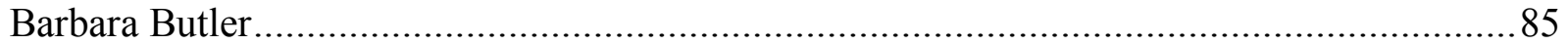

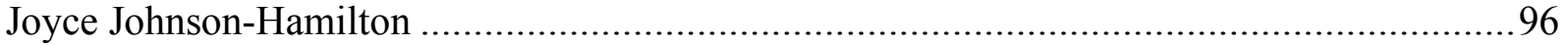

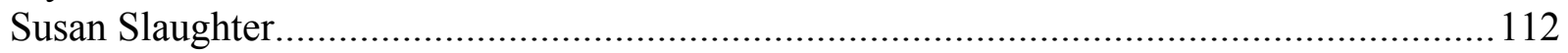

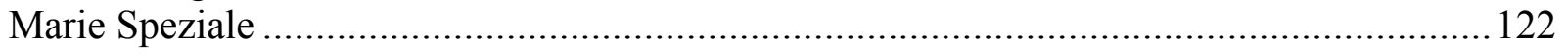

Bibliography .......................................................................................................................132

Curriculum Vitae......................................................................................................................139 


\section{List of Figures}

Figure 1. Alice Raymond ....................................................................................................14

Figure 2. Bessie Gilbert.............................................................................................................16

Figure 3. Mabel Keith, "The Sousa Girl" ...........................................................................................17

Figure 4. Marie McNeil...................................................................................................................18

Figure 5. Florence Louise Horne ...................................................................................................20

Figure 6. Browne "Brownie" Greaton ............................................................................................21

Figure 7. Boston Fadettes Women's Orchestra Brass Section ...................................................25

Figure 8. Edna White.............................................................................................................32

Figure 9. Katherine Rankin............................................................................................................39

Figure 10. Leona May Smith ..................................................................................48

Figure 11. Carole Dawn Reinhart .............................................................................................55

Figure 12. Joyce Johnson-Hamilton .......................................................................................63

Figure 13. Marie Speziale ...........................................................................................................66

Figure 14. Susan Slaughter.................................................................................................68

Figure 15. Barbara Butler ......................................................................................................72 


\section{List of Tables}

Table 1. Music performed by Anna Theresa Berger in London .................................................8

Table 2. Cornetists who performed with Helen May Butler's Band........................................11

Table 3. Cornetists with the Fadettes Woman's Orchestra....................................................26

Table 4. Trumpeters with the Long Beach Women's Symphony Orchestra ............................31

Table 5. Repertoire lists from Aida Quartet Concert Programs.................................................34

Table 6. Edna White Quartette Partial Repertoire List .................................................................37

Table 7. Grace Adams East Partial Repertoire List.................................................................44

Table 8. Percentage of Female Instrumental Players in Selected American Symphony

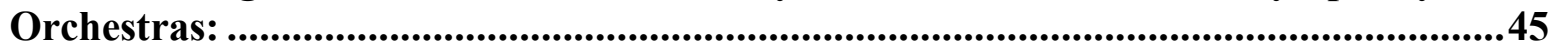

Table 9. Orchestras hiring female horn and trumpet players......................................................47

Table 10. Women's Army Corps Bands Trumpet Roster .........................................................52

Table 11. Marine Corp Women's Reserve Band Trumpet Roster..........................................53

Table 12. Women's Air Force Band Trumpet Roster During the 1950s ...............................54

Table 13. Wind Personnel in Selected U.S. Orchestras (1999-2000 season) .............................76 


\section{Chapter 1 - Introduction}

In 1993 the First International Women's Brass Conference was held in St. Louis, Missouri, featuring many professional female brass players in solo, chamber, and large ensemble performances. For many who attended, it was the first time they had seen so many accomplished female performers of brass instruments in one venue. One special event of the conference was a banquet to recognize women considered to be "pioneer" brass performers. These women were recognized as being distinguished in the field of brass performance at a time when it was an uncommon profession for women. One of those honored was Leona May Smith, a professional trumpet soloist and educator. Her comment when accepting the Pioneer award was, "Thank you for finding me."

Judith Tick and Jane Bowers write in their collection of essays, Women Making Music: The Western Art Tradition, 1150-1950, "The absence of women in the standard music histories is not due to their absence in the musical past. Rather, the questions so far asked by historians have tended to exclude them."2 Their research, and much that has followed, has proven that women hold a legitimate place in the history and development of music performance. Eloise Jenkins states in the introduction to her dissertation, Women as Professional Horn Players in the United States, 1900-2005, that the historical storyline of women as horn players has sometimes become broken. The fact that scholars did not write about women playing horns does not mean that women did not play horns. ${ }^{3}$ Her research has succeeded in filling in some of the gaps in the storyline of women horn players. There is a need to do the same for their trumpet-playing counterparts. The purpose of this study is to identify women trained in the classical tradition who chose to perform trumpet professionally as their full-time career choice, the performance opportunities available to them, the music they performed, and whether or not they encountered particular challenges arising from their attempts to succeed professionally in a discipline mostly dominated by men.

Although many classically-trained female trumpet players have developed successful professional careers in the genres of jazz and commercial music, specific focus for this study was on classical solo and chamber artists, members of full-time professional symphony orchestras, and members of professional bands. I followed the research model established by Jenkins and 1) examined existing writings in monographs, journal articles, and newspaper reportage; 2) conducted interviews with living professional female trumpet artists to document their professional development, achievements and observations; and 3) condensed information from collected orchestral rosters.

As this information was collected and studied, I organized the performers into instrumental performance categories that seemed unique to the their time periods. This study is

\footnotetext{
${ }^{1}$ Cathy Leach, “The International Women's Brass Conference: Personal Reflections," International League of Women Composers Journal (October 1993): 34.

${ }^{2}$ Jane Bowers and Judith Tick, eds., Women Making Music: The Western Art Tradition, 1150-1950 (Urbana and Chicago: University of Illinois Press, 1986), 3.

${ }^{3}$ Eloise Jenkins, "Women as Professional Horn Players in the United States, 1900-2005" (D.M.A. diss., University of Wisconsin-Madison, 2005), 1.
} 
organized differently from Jenkins' study due to the different nature of the instruments, and the different progression towards general social acceptance experienced by the artists. Chapter Two (Brass Bands and the Golden Age of Cornet) discusses the opportunities created by the professional band movement, which allowed women to perform as section players and also as featured cornet soloists. Chapter Three (Women's Ensembles and the Transition from Cornet to Trumpet) focuses on the development of the orchestra and the initiative taken by women in creating their own ensembles. Chapter Four (New Opportunities Resulting from World War II) examines the performance opportunities for women created by men leaving their positions to serve in the armed forces. Chapter Five (Women in Major Symphony Orchestras) examines the initial acceptance of female trumpeters into the major professional symphonies. Appendix A is a table of women who obtained positions in symphony orchestras, and Appendix $\mathrm{C}$ provides transcripts of interviews with select orchestral and solo performers: Barbara Butler, Joyce Johnson-Hamilton, Susan Slaughter, and Marie Speziale. My intent in this research was to be thorough, but no attempt was made to be all-inclusive.

Research on the topic of women and music continues to increase. Online research databases including RILM, Dissertation Abstracts Online, JSTOR, Lexis-Nexis, and several others provided a starting point for discovery of scholarly materials on this topic. Bibliographies that provided many resource citations to further this study included Women in American Music: A Bibliography of Music and Literature by Block and Bates, ${ }^{4}$ Women in American Music: A Bibliography by Skowronski, ${ }^{5}$ and Women in Music: A Research and Information Guide by Karin Pendle. ${ }^{6}$

While there is much research that is devoted to the broad subject of women in music, there is much less that is specific to women brass players, and even less on those who play trumpet. Monographs on women in music used as source material include: Unsung: A History of Women in American Music by Christine Ammer, ${ }^{7}$ Women Performing Music: The Emergence of American Women as Classical Instrumentalists and Conductors by Beth Abelson Macleod, ${ }^{8}$ and Women in Music by Carol Neuls-Bates. ${ }^{9}$ Recently published doctoral documents provided information on brass performers including "All-Women Orchestras in the United States and the Story of the Woman's Symphony Orchestra of Chicago" 10 by Linda Dempf, "Women as Professional Horn Players in the United States, 1900-2005"11 by Eloise Jenkins; and most recently published, “ 'Such Unfeminine Instruments:' Women Brass Musicians in America

\footnotetext{
${ }^{4}$ Adrienne Fried Block and Carol Neuls-Bates, Women in American Music: A Bibliography of Music and Literature (Westport: Greenwood, 1979).

${ }^{5}$ JoAnn Skowronski, Women in American Music: A Bibliography (Metuchen: Scarecrow Press, 1978).

${ }^{6}$ Karin S. Pendle, Women in Music: A Research and Information Guide (New York: Rutledge, 2005).

${ }^{7}$ Christine Ammer, Unsung: A History of Women in American Music (Portland: Amadeus, 2001).

${ }^{8}$ Beth Abelson Macleod, Women Performing Music: The Emergence of American Women as Classical Instrumentalists and Conductors (Jefferson, NC and London: McFarland, 2001).

${ }^{9}$ Carol Neuls Bates, Women in Music (Boston: Northeastern University Press, 1996).

${ }^{10}$ Linda Dempf, "All-Women Orchestras in the United States and the Story of the Woman's Symphony Orchestra of Chicago" (D.M.A. diss., Indiana University, 2002).

${ }^{11}$ Jenkins, "Women as Professional Horn Players in the United States."
} 
before $1940 " 12$ by Joanna Ross Hersey. D. Antoinette Handy's Black Women in American Bands and Orchestras was the main source for information regarding African American performers. ${ }^{13}$

The International Trumpet Guild Journal published several articles that were used in this study including those on Marie Speziale, ${ }^{14}$ Ernest S. Williams, ${ }^{15}$ and Carole Dawn Reinhart, ${ }^{16}$ as well as articles on trumpet sections in symphony orchestras by John Ossi ${ }^{17}$ and Stefan Cooper. ${ }^{18}$ The International Association of Women in Music Journal, the Women of Note Quarterly and the Music Educators Journal also contained articles pertinent to this study, including those by Susan Fleet, ${ }^{19}$ Douglas Myers and Claire Etaugh, ${ }^{20}$ and William Osborne, ${ }^{21}$ to name a few. Paul Trescott supplied pictures of the lady cornet soloists. Dr. Jill Sullivan provided information regarding the women's military bands. Eloise Jenkins supplied orchestral rosters used in her research, while Norman Schweikert verified information collected from those rosters and provided additional source material.

Articles obtained from reportage included those in the International Women's Brass Conference Newsletter, the Brass Bulletin, Windplayer, and other similar publications. Additional online resources for information regarding specific performers included the Newspaper Archive Online, Old Fulton New York Post Cards, the University of Iowa Digital Collection, and the New York Times Archives. The International Women's Brass Conference Directory of Women Performers ${ }^{22}$ was used to obtain names of known female trumpet players.

The format of the interviews was unstructured, allowing for the different strengths and areas of experience for each woman to be highlighted. The purpose was not to prove any particular point, but to document these women's lives and careers, and perhaps gain some insights from them regarding their experiences building successful careers in a historically male-

\footnotetext{
${ }^{12}$ Joanna Ross Hersey, “'Such Unfeminine Instruments': Women Brass Musicians in America Before 1940" (D.M.A. diss., University of Hartford, 2006).

${ }^{13}$ D. Antoinette Handy, Black Women in American Bands and Orchestras, 2nd ed. (Lanham: Scarecrow Press, 1998).

${ }^{14}$ Karen Gustafson, "Marie Speziale: Performer, Teacher and Pioneer," International Trumpet Guild Journal 26, no. 4 (June 2002): 7-14.

${ }^{15}$ Keith Robert Winking, "Ernest Williams, Virtuoso and Educator: A Biographical Survey of his Philosophies and Techniques" (D.M.A. thesis, The University of Texas at Austin, 1993).

${ }^{16}$ Robyn Card, "A Life of Firsts: An Interview with Carole Dawn Reinhart," International Trumpet Guild Journal 30, no. 2 (January 2006): 6-13.

${ }^{17}$ John Ossi, "Trumpet Personnel in Major North American Orchestras: 1989," International Trumpet Guild Journal 14, no. 1 (September 1989): 71-73.

${ }^{18}$ Stefan Cooper, "The Trumpet Players of the San Francisco Symphony, 1911-1995," International Trumpet Guild Journal 20, no. 3 (February 1996): 32-41.

${ }^{19}$ Susan Fleet, "Edna White Chandler: A Brasswoman Pioneer," Women of Note Quarterly 2, no. 4 (November 1994): 7-12.

${ }^{20}$ Douglas Myers and Claire Etaugh, "Women Brass Musicians in Major Symphony Orchestras: How Level is the 'Playing' Field?" International Alliance for Women in Music Journal 7, no. 3 (2001): 28-31.

${ }^{21}$ William Osborne, "Women in Major Orchestras: An Update," International Alliance for Women in Music Journal 7, no. 3 (2001): 31.

22 "Women Brass Musicians: Past and Present, Professionals in Performance and University Education." (St. Louis: International Women's Brass Conference, 1993).
} 
dominated profession. The basic interview questions for each woman were the same, and the interviews were conducted via the telephone.

Although specific references may be in short supply, some researchers have been able to document that women have been playing trumpet professionally since the Middle Ages. My intent was to gather information on those who have had success in the United States, during the specific time period of the late nineteenth century through the late twentieth century, and present it so others may have a basis for further exploration. The interviews will serve as a way to discover how female trumpet players have dealt with the unique experiences generated from their choice of profession. 


\section{Chapter 2 - Brass Bands and the Golden Age of Cornet}

During the latter half of the nineteenth century, bands throughout the United States were an integral part of the community. Considered to be suitable entertainment for virtually any occasion, bands were highly visible and audible, whether it was lauding a visiting dignitary, marching in parades, providing dance music at social events, or announcing that the circus had come to town. Advancements in the manufacture and design of brass instruments, including the invention of the valve, resulted in more performers being able to obtain and learn how to play them. These instruments were loud, durable, and able to carry the melody, making them popular for outdoor performances. ${ }^{1}$

\section{The Family Bands}

In The Music Men, a monograph on the brass band movement, Margaret and Robert Hazen group the professional bands of that time into five categories: military and naval bands, local bands, circus bands, touring concert bands, and family bands. The family bands were one outlet that allowed many young women to be able to play brass instruments professionally. Female musicians were often featured prominently and, in many cases, comprised the entire band. $^{2}$

William Henry Mitchell formed one such band in the mid 1890s, when his wife died and he became a widower with six daughters. With his daughters, he formed the Mitchell Concert Band and traveled on and off for eleven years throughout Wisconsin, Iowa, Minnesota, and Nebraska. Their program consisted almost entirely of military music. ${ }^{3}$

The Noss Family of New Brighton, Pennsylvania, was advertised as "Eight in Number, All One Family." Their publicity card (ca. 1890) listed the talents of each family member. May Noss was listed as performing violin, alto horn, cornet, piano, banjo, and vocals. Her youngest sister, who received top billing as "Petite" Bertha Noss, the Child Wonder, was described as performing snare drum, bass drum and cymbals (at the same time), bellaphone, metalaphone, violin, cornet, xylophone, musical specialties, piano, vocal, character sketches, drum major's baton drill, manual of arms, and bayonet exercise. ${ }^{4}$ This description demonstrated the ensemble's ability to capitalize on the novelty of having a child performer who was female.

The instrumentation of such family groups was diverse, and as exemplified by the Noss Family, the performers had to be versatile. Their programs consisted of band music, vocal selections, and instrumental solos as well as non-musical numbers. Having female members was

\footnotetext{
${ }^{1}$ Margaret Hindle Hazen and Robert M. Hazen, The Music Men: An Illustrated History of Brass Bands in America, 1800-1920 (Washington, D.C.: Smithsonian Institution Press, 1987), 1-2, 11.

${ }^{2}$ Ibid., 21-34.

${ }^{3}$ Ibid., 34-35.

${ }^{4}$ Ibid., 34.
} 
an obvious difference from the other professional bands, which many group leaders used to their advantage by treating their participation as a novelty. ${ }^{5}$

The Strohl Family Band of Pottstown, Pennsylvania was one of the larger bands popular in the 1880s. This ten-member group consisted of three cornets, two alto horns, baritone, tuba, snare drum, and bass drum. Their publicity card pictured mother, father, four daughters, and four sons, with one of the daughters holding a cornet. The five Shepard children, along with their father, comprised the Shepard Family Band. Based in Massachusetts, they were popular in the 1890s. One can see the oldest two daughters holding cornets in their photographic publicity cards. $^{6}$

\section{Anna Teresa Berger}

Hazen and Hazen indicate that many of the family bands dissolved as the children matured. However, these ensembles provided performance experiences for the young lady cornetists, which allowed some of them to develop musical careers that would last a lifetime. ${ }^{7}$ One example of such a performer was Anna Teresa Berger. Born in Baltimore on May 16, 1853, Berger began performing on cornet when she was ten years of age. Daughter of an organ-maker, she performed for the first time with her family troupe along with her brothers (Henry and Fred) and sister (Louisa) on April 7, 1862 for a benefit to assist sick and wounded Union soldiers. In 1863, the Berger children performed with the MacFarland Dramatic Company, and in 1864 they joined the Carter Zouave Troupe. ${ }^{8}$ They were with the Zouave Troupe for two years, performing an act that consisted of singing, dancing, playing instruments, and performing military drills while wearing a miniature version of the Zouave military uniforms. ${ }^{9}$

While touring with the Zouave Troupe, they met and befriended Sol Smith Russell, a comedian and actor. Russell married Louisa Berger, and in a letter he wrote on January 15, 1868, he shared his concerns about Anna Berger and her constant touring. She was fourteen years old at the time. (Text appears in Russell's own style of writing.)

I wish she would marry some Rich old cuss that she might Retire from her Profession and stop Blowing that confounded cornett. I Declare it makes me shiver when I think of her Playing so much for fred [Berger]she is to Delicate to play and Blow that horn you try and let her go to York [Pennsylvania] and live with aunty about one year and she can be fed on good wholesome food and she could go to School and could Practice on her violin all the time and I will warrant in one year she will come from home a fine stout hearty

\footnotetext{
${ }^{5}$ Ibid.

${ }^{6}$ Ibid., 34-35. The youngest member in the picture is little girl sitting by a tambourine, the tenth member of the band.

${ }^{7}$ Ibid.

${ }^{8}$ Betsy G. Miller, “Anna Teresa Berger, Cornet Virtuoso,” International Trumpet Guild Journal 22, no. 3 (February 1998): 43.

9 June Lloyd, "York Berger Family Makes it Big," York's Historical Connection, comment posted January 4, 2009, http://www.yorkblog.com/universal/2009/01/york-berger-family-musiciansm.html\#more (accessed March 4, 2009).
} 
girl for I think that is where the trouble lies annie is Exposed to much to being up nights, and Eating to many sweet meats and this kind of living don't atall agree with her Delicate constitution take my advise and let her have a good Rest and let her go to school if you Posibly can. ${ }^{10}$

The Bergers were touring with the Peak Family Swiss Bell Ringers in 1868 when Russell wrote this letter, and eventually formed their own troupe with him. In the early 1870 s, they toured the United States including performances in New Orleans. One reviewer reported that Berger performed a solo on her gold cornet, a gift from friends in New York presented to her in 1871. Following appearances in New Orleans, they traveled to Havana, Cuba where audiences showered her with money thrown on the stage. A report in The Columbia Register on January 27, 1878 said,

Miss Anna Teresa Berger, the fair cornetist of the Berger Family Troupe, was recently the recipient of a complimentary benefit in Havana, Cuba ... When she appeared before the footlights, white doves with silken ribbons round their necks, to which were attached poetic tributes, were sent flying towards her from the boxes, and she received many valuable presents, consisting of jewelry, fans, lace handkerchiefs, etc., which were thrown to her from her numerous admirers in that city. The occasion was honored by the presence of the Captain General of Cuba, the governor of Havana, and the principal military and civil authorities of the island, including the elite of Havana society. ${ }^{11}$

During the 1875-76 season, the Bergers appeared as the Berger Family Ladies' Orchestra with Anna Berger's cornet playing a major feature of the act. The Bergers had toured together as a family for seventeen years with the younger brothers and sisters joining the older four siblings (Fred, Henry, Anna, and Louisa) as they grew old enough to perform. On May 8, 1880, the troupe gave their farewell concert in Troy, New York. ${ }^{12}$ Louisa Berger and one brother had died, and other family members had married, or were thinking of getting married. ${ }^{13}$ Anna married Leigh S. Lynch, treasurer of the Union Square Theatre in New York City. The experiences she had gained while performing with the different troupes laid the foundation for her to establish a successful solo performance career. As a soloist, she continued to perform in New York City, on the vaudeville circuits, and with several of the well-known concert bands in the United States, including two appearances with Rudolf Bial's Orchestra at the Metropolitan Casino in New York City. The New York Mirror (January 7, 1882) gave a favorable review of both performances, writing the following about the first:

Miss Berger played a cornet solo exquisitely. There is no manner of doubt that this lady is by far the best female cornet player that ever blew sweet music out of "sounding brass." Her execution is equal to that of the greatest masters of the instrument, and her tone is wonderful for a woman. ${ }^{14}$

\footnotetext{
${ }^{10}$ Miller, "Anna Teresa Berger," 43.

${ }^{11}$ Ibid., 45.

${ }^{12}$ Ibid.

${ }^{13}$ Lloyd, "York Berger Family Makes it Big."

${ }^{14}$ Miller, "Anna Teresa Berger," 45.
} 
In 1889, Freeman Thomas engaged Berger to appear at the Covent Garden Promenade Concerts in London. At her first appearance on August 17, she played "Grand Russian Fantasia" by Jules Levy. By the end of August, she was appearing nightly and was a featured part of the performance. She continued to appear until November $4 .{ }^{15}$ In the United States, reports of her successful tour were printed in various music publications, including the following from The Musical Visitor:

Anna Teresa Berger, sister-in-law of Sol Smith Russell, is the leading cornetist of the world. At her lodgings she has a small room fitted up with padded walls and ceiling and draped doors, and there she practices night and day on the gold and silver cornets that have been presented to her by her admirers. ${ }^{16}$

Selections that she performed during the tour were typical of the repertoire performed regularly by her male colleagues, and some were composed by her teacher, Jules Levy (see Table 1). At some point in her career, she gave joint performances with cornetist Louis Boos, winning contests with him. ${ }^{17}$ Boos also wrote one of the compositions she performed on her London tour.

\section{Table 1. Music performed by Anna Theresa Berger in London}

\begin{tabular}{ll}
\hline Composer & Piece \\
\hline Jules Levy & $\begin{array}{l}\text { Polka Mazurka } \\
\text { Maud Valse } \\
\text { Young America } \\
\text { The Levyathan Polka }\end{array}$ \\
\hline Jules Legendre & Anna Polka \\
\hline Louis Boos & Teresa Waltz \\
\hline Michael W. Balfe & Then You'll Remember Me \\
\hline John Hartmann & Lizzie Polka \\
\hline F. Innis & Folie de Bergere \\
\hline H. Millard & Waiting \\
\hline Unknown & $\begin{array}{l}\text { Zerlina Polka } \\
\text { Promenade Polka } \\
\text { Lee's Duet for Two Cornets }\end{array}$ \\
\hline
\end{tabular}

Anna Berger and Leigh Lynch raised five children: Nani, Leigh, Dorothy, Eugene, and William. Leigh senior was heavily involved with the theatre in various capacities and arranged two world tours for National League baseball clubs. Young Leigh pitched for the New York Giants. Berger died February 25, 1925 in Jackson, Michigan at the age of seventy-one. ${ }^{18}$

\footnotetext{
${ }^{15}$ Ibid., 46.

16 "Musical Notes and News," The Musical Visitor: a Magazine of Musical Literature and Music, 18831897 19, no. 4 (April 1890): 90.

${ }^{17}$ Richard I. Schwartz, "The Cornet Compendium: The History and Development of the NineteenthCentury Cornet," http://www.angelfire.com/music2/thecornetcompendium/index.html (accessed March 4, 2009).

${ }^{18}$ Miller, “Anna Teresa Berger,” 46.
} 


\section{Georgie Dean Spaulding}

Another artist who grew from a similar family tradition was Georgie Dean Spaulding. Her father, William P. Spaulding, had created the Spaulding Minstrel Company, which was most likely where the younger Spaulding received her musical and business training. ${ }^{19}$ A versatile musician, she sang and performed on several instruments, including the cornet and harp. Following in her father's footsteps, she founded the Spaulding Concert Company, which included the Ladies' Cornet Band and the Spaulding Bell Ringers. Nellie Daniels, cornet soloist, joined the Company in 1873. A short time later the Ladies' Cornet Band performed in Vermont, led by Ms. Spaulding and her "gold cornet." 20 On Monday, December 29, 1873, The Greenfield Gazette and Courier printed a review of a performance given by the Company in Greenfield, Massachusetts. It provides insight into the diverse type of programming that was common at that time:

The concert by the Spaulding Bell Ringers Fri. night had a fair attendance, notwithstanding the storm. The entertainment was far above the average, the programme [sic] including many features that were a novelty to the audience, for though this is one of the oldest companies traveling, there is nothing stale or played out in the varied treat which they furnish. Georgie Dean Spaulding and Nellie Daniels appeared as lady cornetists, and proved that this instrument can be played as well by the fair as the sterner sex. The difficult feat of the former, of playing " The Fisher's Hornpipe " with one hand and "Yankee Doodle" with the other upon a harp, and at the same time singing "Tramp, Tramp" called forth no little wonder and applause. The bell ringing, singing, etc. was as always, very fine. ${ }^{21}$

Daniels passed away in mid-July, 1875 , at the young age of $29 .^{22}$ Spaulding continued to perform with her company for a short time thereafter.

\section{The Women's Bands}

During the height of the band era near the turn of the century, bands were either amateur or professional in nature. This was the case for the all-women groups as well as their male counterparts. On the rare occasion that a band was comprised of both men and women, it was usually due to being located in a small town where often there were not enough men to staff a full ensemble. Most ladies' bands were conducted by a man. ${ }^{23}$ One exception to this was the Helen May Butler's Ladies' Military Band.

\footnotetext{
19 "Picture History: The Primary Source for History Online," http://www.picturehistory.com (accessed December 28, 2008).

${ }^{20}$ Ammer, Unsung, 119.

${ }^{21}$ Franklin County News Archive, "Archive Article: Stunt Performers," http://www.publicationarchive.com/archiveArticle.cfm?g=184\&cs=230\&num=400 (accessed January 13, 2009).

${ }^{22}$ Ibid.

${ }^{23}$ Hazen, The Music Men, 55-56.
} 
Born in New Hampshire May 17, 1867, ${ }^{24}$ Butler studied music, along with her academic subjects, and became accomplished on both violin and cornet. In 1891, she organized her first ensemble, the Talma Ladies' Orchestra, which carried the instrumentation of violins, viola, flute, clarinet, cello, cornet, and baritone. With Butler serving as conductor and cornet soloist, the group performed locally, in Rhode Island, receiving favorable reviews. In 1898, seeing the commercial possibilities for an all-women's military-style band conducted by a female, Butler transformed the group from an orchestra into a uniformed ladies' brass band. ${ }^{25}$ Performing first as the U.S. Talma Ladies' Military Band, the group later became known as the Helen May Butler's Ladies' Band. ${ }^{26}$ By 1902, it became known as the American Ladies' Grand Concert Band. $^{27}$

The instrumentation, dress, and programming were modeled after the successful professional male bands, such as John Philip Sousa's concert band. The women performed both popular and classical music that included transcriptions, descriptive pieces, popular songs, and marches. Butler's small ensembles of around fifteen pieces consisted of a core of brass players, with the possible supplement of one or two clarinets. The larger group of forty to fifty players included a full woodwind complement. ${ }^{28}$

Butler was an important figure for professional women cornetists, not only as a working cornet soloist, but also because she employed many female cornet players (as well as other female musicians) in a professional capacity. Considered to be one of the best, if not the best professional women's band, the group toured the continental United States intermittently from 1900 to 1912. Dr. Patricia Backhaus, a recognized scholar on Helen May Butler, lists twentyseven different cornet players who performed with the ensemble (see Table 2). ${ }^{29}$ Of the many performance venues hosting the ensemble, most notable were those concerts given at Madison Square Garden for the Women's Exhibition Exposition, for the South Carolina Interstate and West Indian Exposition in 1902, and for the Louisiana Purchase Exposition in St. Louis in 1904. The band also appeared for a ten-week engagement at the Pan-American Exposition held in Buffalo in 1901. Butler's ensemble was the only women's band to appear. ${ }^{30}$

\footnotetext{
${ }^{24}$ William H. Rehrig, The Heritage Encyclopedia of Band Music: Composers and their Music, ed. Paul E. Bierley, vol. 3 (Westerville, Ohio: Integrity Press, 1991), 119.

${ }^{25}$ Patricia Backhaus, "An Adamless Garden of Musical Eves: A Short History of Helen May Butler, The Female Sousa and Her American Ladies' Concert Band," Kongressbericht Feldkirch/Vorarlberg 1992 (1994): 182.

${ }^{26}$ Hazen, The Music Men, 186.

27 “Helen May Butler," http://www.wbutler.com/link/Biographies/Butler/HelenMayButler/Index.html (accessed 5 February 2009).

${ }^{28}$ Hazen, The Music Men, 186-87.

${ }^{29}$ Patricia Backhaus, "Source Guide for Research on Women Instrumentalists, c. 1840-1960: A Guide to Documentation of Musical Careers of Women String, Woodwind, Brass and Percussionists," http://www.adagioconcepts.com/cornetpat.html (accessed November 15, 2008-March 2, 2009).

${ }^{30}$ Hazen, The Music Men, 189.
} 
Table 2. Cornetists who performed with Helen May Butler's Band ${ }^{31}$

\begin{tabular}{ll}
\hline Musician & Year(s) Performed in the Band \\
\hline Ida Abbott & $?$ \\
\hline Emma L. Adams & $?$ \\
\hline Jessie Allardice & 1899 and 1900 \\
\hline Lillian Andrews & 1899 and 1901 \\
\hline Annie Bettony & 1899 and 1900 \\
\hline Esther Carnes & 1905 \\
\hline Jenny M. Clayson & 1904 \\
\hline Iva Cordeaux & 1902 \\
\hline Elizabeth Dickinson & $?$ \\
\hline Virginia Elliott & 1903 \\
\hline Bessie Gilbert & 1903 \\
\hline Hazel Goff & 1911 \\
\hline [unknown] Goodelle & 1911 \\
\hline Florence Tremaie Hamilton & 1905 \\
\hline [unknown] Harris & 1911 \\
\hline Fran Hazel & $?$ \\
\hline Anna Hoffman & 1909 \\
\hline Maud S. Hopkins & $1903(?)$ \\
\hline Lillian Littleholes & $?$ \\
\hline Eleanor Piper & $1899-1901$ \\
\hline Laura Antoinette Reiter* & 1910 and 1911 \\
\hline Nettie Reiter* & 1910 and 1911 \\
\hline Laura (or Susie) Schofield & 1906 \\
\hline Ella Thomas & 1906 \\
\hline Alice Vashti & $?$ \\
\hline Emma Wollersheid & 1902 \\
\hline Alice Wyker & 1910 \\
\hline Laur Anting Ren & \\
\hline
\end{tabular}

*Laura Antoinette Reiter and Nettie Reiter are most likely the same person. She was also referred to as Lora Antoinette Reiter.

The American Ladies Grand Concert Band publicity brochure published in 1910 indicates that another lady cornet soloist served as the "directress" of the band, at least for a time, during the 1910 and 1911 seasons. Lora Antoinette Reiter, "The World's Greatest Lady Cornet Virtuoso," was "Specially Engaged as Soloist and Directress." The brochure provides concert reviews from various newspapers. The Chicago Theatrical Review addressed the abilities of the ensemble,

This will close their two weeks' engagement at this famous resort [Riverview Park], where they have played before the largest audiences ever assembled in front of the band

\footnotetext{
${ }^{31}$ Backhaus, "Source Guide for Research on Women Instrumentalists."
} 
shell. Each and every one of their excellent programs were well rendered and each and every one of the ladies have proven beyond all doubt that the great compositions, as well as the more popular, are readily within their scope and several special numbers of the band have also proven that even the larger musical instruments employed in band work are not for men alone. The concerts rendered by this excellent organization are most charming in every way. ${ }^{32}$

The review from the Leavenworth Post is more typical of those written about women instrumental performers at this time, mixing comments on appearance with musical critiques,

The girls are all very good looking and best of all they are artists, as proven last night when they gave their first concert, everyone being loud in their praise. One old gentleman who fell in love with the whole band declared they were really a bunch of "American Beauties." They came here direct from Riverview Park, Chicago. The band is one of the best musical organizations that ever appeared in this city. ${ }^{33}$

The ensemble was disbanded in 1912. Butler indicated that, at this time, the band movement in general was losing momentum due to the growing popularity of other forms of entertainment. Settling in the Cincinnati, Ohio area, she continued to perform as a soloist while raising a family and pursuing other interests. ${ }^{34}$ She died June 16, 1957 at ninety years of age. ${ }^{35}$

Another professional touring ladies' concert band conducted by a woman was the Navassar Ladies' Band. Under the direction of Gussie G. Dial, the fifty-piece ensemble wore military style uniforms of red, white, and blue. In a review of a concert given at the Hippodrome on October 21, 1906, the New York Times stated that Dial "wielded the baton with a good deal of energy and seemed to have her large corps of musicians in good control," and that the ensemble played to a "well-filled" house.

An article in The San Francisco Call in 1909 reported that the band was performing at Idora Park in Oakland, California. The reporter described the women as being "as fair to look upon as engaging to hear." The program included separate cornet solos by Vivian Hutchings and Nellie Mae Hone, "who has the reputation of being the foremost woman cornetist of the world." Hoone was to perform "Had I a Thousand Lives to Live." Other items on the program were Verdi's "Anvil Chorus," the Cinderella and Die Fledermaus overtures, and Schubert's "Serenade." ${ }^{37}$ Additional newspaper reports indicate other performances by the band for the

\footnotetext{
32 “American Ladies Grand Concert Band," Redpath Chautauqua Collection, University of Iowa Libraries Special Collections Department, http://sdrcdata.lib.uiowa.edu/libsdrc/details.jsp?id=/amerladies/1 (accessed March 8, 2009).

${ }^{33}$ Ibid.

${ }^{34}$ Hazen, The Music Men, 189.

35 "Helen May Butler,"

http://www.wbutler.com/link/Biographies/Butler/HelenMayButler/HelenMay3.html (accessed 21 April 2009).

36 "Women's Band at the Hippodrome," The New York Times, 22 Oct 1906 (Proquest).

37 "Navassar Band Plays at Idora," The San Francisco Call, 13 June 1909, p. 29

(NewspaperARCHIVE.com).
} 
Michigan State Fair in September 1909, the Alberta (Calgary) Provincial Exhibition in 1910, and the Saginaw (Michigan) Industrial Exhibition in September 1911.

Lillian Sieger was a cornetist with the Navassar Band who endorsed the Conn New Wonder Cornet. A postcard published in 1915 shows the artist holding the Wonder Cornet and her endorsement reads, "I'm so glad I adopted the New Wonder Cornet. Never enjoyed playing as now. Conn Cornets are far in the lead and help players to be so.",38

Another soloist who appeared with the band was Florence Louise Horne, who also performed with the Boston Fadettes. Esther E. Carnes from Champaign, Illinois, was with the band for six years. ${ }^{39}$ Carnes left the ensemble when she married. Replacing personnel for this reason was a common issue in the women's bands. When questioned about it, the manager of the Navassar band indicated that he had lost eight members through marriage. He stated in an article published in the Kansas City Journal on July 25, 1908 that

When a man musician marries he usually takes his wife with him for the honeymoon, but the women musicians can't very well travel with a husband tagging along with them, mostly because hubby must have a job somewhere. So the women leave the band when they marry. ${ }^{40}$

Other women's bands were in existence during the late nineteenth century, but information on specific personnel is scarce. In 1888, the 120-piece Ladies Band of Audubon, Iowa gave a performance at the annual meeting of the Northwestern Band Association. ${ }^{41}$ In Ashland, Oregon, a Ladies' Cornet Band was formed around 1889. This seven-piece ensemble carried two cornets, two alto horns, tenor, bass, and E-flat tuba. ${ }^{42}$

African American women also formed their own ensembles that provided both popular and elite art music entertainment. D. Antoinette Handy referred to these ensembles as "all double-minority" groups. Viola Allen led the sixteen-piece Colored Female Brass Band from East Saginaw, Michigan in the late 1880s and appeared as the featured cornet soloist. Mrs. Roper Johnson and Nettie Lewis were cornet players with George Bailey's Female Brass Band of Indianapolis. ${ }^{43}$

\footnotetext{
38 "Gift Shop Postcards," National Music Museum, http://www.usd.edu/smm/GiftShop/PostcardsBW/LillianSieger.html (accessed January 13, 2009).

${ }^{39}$ Lee County Iowa GenWeb Project, “Articles from Montrose, Iowa Journal, 10 February 1910," transcr. by Connie (Dobson) Putthoff, http://iagenweb.org/lee/montjourn/1910.htm (accessed January 12, 2009).

40 "Cupid Plays Havoc in Band: Navassars' Manager is Kept Busy Looking for New Musicians," The Kansas City Journal 100-Year Weblog, http://www.vintagekansascity.com/100yearsago/labels/arts.html (accessed January 27, 2009).

${ }^{41}$ Ammer, Unsung, 102.

${ }^{42}$ Hazen, The Music Men, 55-6.

${ }^{43}$ Handy, Black Women in American Bands and Orchestras, 33, 37, 164.
} 


\section{The Cornet Soloists}

Hazen and Hazen indicate that, in the hierarchy of the band ensemble, the solo cornet position was "one step above the rank and file players." An artist who was better trained and thus better paid usually filled this chair. In the smaller ensembles, the first cornetist usually played the lyric solo passages, performed the standard theme-and-variation showpieces, and (as demonstrated by Helen May Butler) could even have been the leader of the band. The bigger touring ensembles usually carried with them a "roster of virtuosi" who performed specially chosen solo works to electrify the crowds. ${ }^{44}$

\section{Alice Raymond}

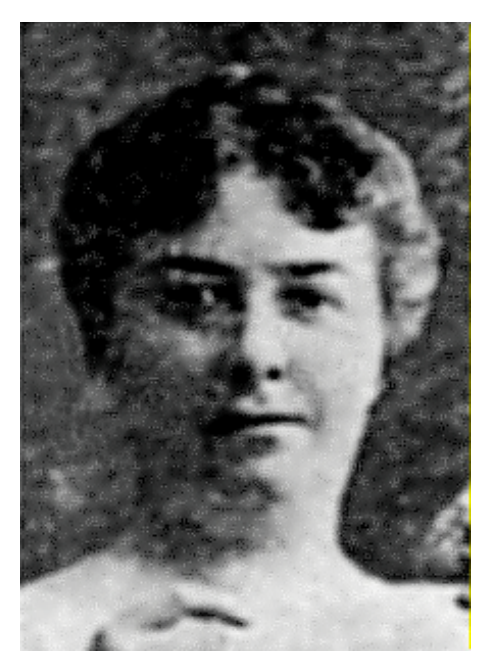

Figure 1. Alice Raymond ${ }^{45}$

Considered by many to be one of these "virtuosi," Alice Raymond was a free agent who negotiated her own seasonal contracts with the bandmasters. ${ }^{46}$ It was quite unusual for a woman to handle her own business affairs during this time. Even Helen May Butler had a male agent acting as her intermediary. Raymond performed in music halls and appeared as a guest soloist with several prominent concert bands, including those conducted by William S. Mygrant and Thomas Preston Brooke. ${ }^{47}$ She replaced Bohumir Kryl in Brooke's Chicago Marine Band for the 1901 and 1902 seasons. ${ }^{48}$ This was considered by some to be a "bold step" taken by Brooke. Historian Arthur Bradley indicated that

\footnotetext{
${ }^{44}$ Hazen, The Music Men, 36.

${ }^{45}$ From Pioneers in Brass by Glenn D. Bridges, 4th ed., used with permission from Paul T. Jackson, Trescott Research.

${ }^{46}$ Hazen, The Music Men, 36.

${ }^{47}$ Glenn Bridges, Pioneers in Brass, CD-ROM (Trescott Research, 2001).

${ }^{48}$ Schwartz, "The Cornet Compendium."
} 
[Raymond] was already a recognized star and served admirably, without trying to match the spectacular technique of Kryl. One of Alice's specialties was a snappy Swiss Polka. She had a warm tone and lilting rhythm and a mastery of phrasing that fit the Brooke popular dance format to perfection. It may have been the popularity of Alice Raymond that induced Barnum \& Bailey to feature Jessie Miller as cornet soloist during their 1906 season. ${ }^{49}$

Similar to other musicians performing during that time, Raymond moved from band to band, or act to act. Appearing in the "General Mention" column of The New York Times on January 20,1885, Raymond was reviewed for a performance that was part of a variety act that included a vocalist, a rope skipper and endurance dancer, and a four-member lady acrobat team: "Miss Alice Raymond was a rather pleasant-looking young lady, who had so far forgotten her duty to humanity as to learn to play the cornet, and she played it well. ${ }^{, 50}$ Apparently the author of the article believed cornet-playing to be a move away from the more traditional "duties" that conventional society expected of a woman.

In a historical series of cornet talks given by Herbert L. Clarke, he referred to Raymond, along with Jean-Baptiste Arban, Louis A. St. Jacome, William Northcott, Jules Levy and others, as one of the "great" cornetists. In this talk, entitled King of the Wind Instruments, he said the following about their struggles to succeed and reach the top of their profession:

The celebrated cornetists won fame away from hometowns, and in foreign countries; this gives them an international reputation. All have passed away but each has left behind a name in the "Hall of Fame," which should be preserved in the memory of every cornet player as an incentive to strive for renown and fame. ${ }^{51}$

The fact that Herbert L. Clarke, one of the pre-eminent cornet soloists of his time, considered her to be his peer is indicative of her abilities and her success. Raymond's recording of the Richard Strauss "Lullaby" is included on the International Trumpet Guild Compact Disc produced in 1995, entitled Cornet Solos by Pioneer American Recording Artists made Prior to 1906. ${ }^{52}$ Two other recordings, "Bonnie Sweet Bessie" and "Swiss Fantasie," can be heard on the CD-ROM, Pioneers in Brass, published by Trescott Research. ${ }^{53}$

\footnotetext{
${ }^{49}$ Arthur Bradley, On and Off the Bandstand (New York: iUniverse, 2005), 11.

50 “Archives: General Mention," New York Times, 20 January 1885 (Proquest).

${ }^{51}$ Bridges, Pioneers in Brass.

${ }^{52}$ International Trumpet Guild, Cornet Solos by Pioneer American Recording Artists Made prior to 1906, Seth B. Winner Sound Studios, CD ITG-004, 1994.

${ }^{53}$ Bridges, Pioneers in Brass.
} 


\section{Bessie Gilbert}

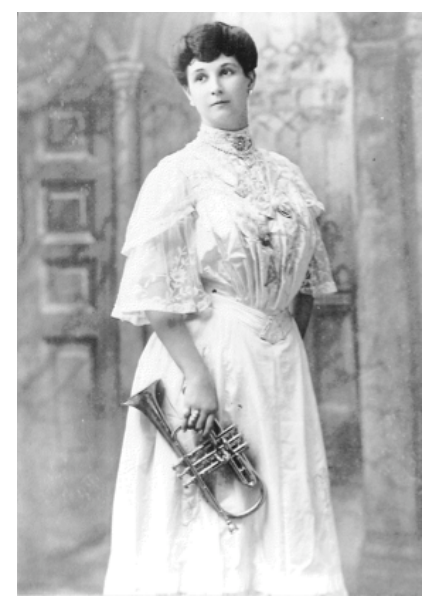

Figure 2. Bessie Gilbert

Bessie Gilbert performed as a cornet soloist with several different vaudeville companies, and eventually formed her own. She was billed as "The Wizard of Cornet! Levy's only Rival!" and "The Undisputed Champion Lady Cornetist of the World" when she appeared with the Adam Forepaugh All-Star Vaudeville Company in $1887 . .^{54}$ The Syracuse Journal, on September 23, 1899, advertised her appearance as cornet soloist for performances given by Gaylord's Concert Band each day of the Onondaga County Fair October 3-6, 1899. ${ }^{55}$ The Evening Telegram told of an audience of over one thousand people at the October 4 concert and called her performance the main attraction, along with the fireworks. ${ }^{56}$ Also in that year, her name appeared as part of an advertisement for the C.G. Conn "New York Wonder Cornets." She is listed along with Alice Raymond, Herbert Clarke, Jules Levy, Walter Smith, and many others as "soloists who have become distinguished in their profession, all of whom pronounce it the most wonderful cornet of the century.",57

Gilbert performed at least one season as part of Helen May Butler's Concert Band, during $1903 .^{58}$ She also performed at the New York State Fair in Syracuse in 1913. The Syracuse Journal (September 9, 1913) reported that the concert opened with a solo performed by "Miss Bessie Gilbert, daughter of the famous soloist with the Gilmore band." She closed the concert with a performance with Patrick Conway's band. The article also lists her as acting as the "musical director for the entire spectacle." ${ }^{, 59}$ Evidence that she performed as late as 1918 is given

\footnotetext{
54 "Bandwagon, November-December, 1958," Circus Historical Society, http://www.circushistory.org/Bandwagon/bw-1958Nov.htm (accessed January 10, 2009).

55 “Onondaga County Fair," Syracuse Journal, 23 September 1899 (Old Fulton NY Post Cards).

56 "Patrons Day at the County Fair," Evening Telegram, 5 October 1899 (Old Fulton NY Post Cards). ${ }^{57}$ American Federationist: Official Magazine of the American Federation of Labor, 6 no. 10 (December 1899): i (Google Books).

${ }^{58}$ Backhaus, "Source Guide for Research on Women Instrumentalists."

59 "Syracuse Host to Thousands of State Fair Guests," Syracuse Journal, 9 September 1913 (Old Fulton NY Post Cards).
} 
in an announcement appearing in the July 31 edition of the New York Clipper. She was scheduled to appear at Proctor's Twenty-Third Street Theatre as part of her own troupe, Wills, Gilbert and Company. Gilbert, "remembered as the famous lady cornetist," was to perform "There's a Long, Long Trail." The Clipper wrote, "she plays it splendidly and the effect is thrilling, indeed."

\section{Mabel Keith}

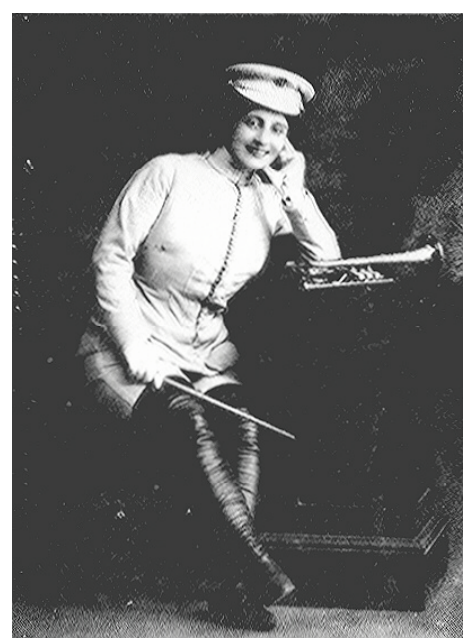

Figure 3. Mabel Keith, "The Sousa Girl"61

Another cornetist of note was Mabel Keith. Born November 7, 1883 in Holdredge, Nebraska, Keith was taught to play piano by her mother. Fascinated by her brother's cornet, she was given lessons on the instrument. In 1899, she studied with Jules Levy for three months at the C. G. Conn Conservatory in Elkhart, Indiana, and after graduating from the program, she returned to Nebraska to make her solo debut on cornet. She learned conducting techniques from John Philip Sousa, who dubbed her "The Sousa Girl." With that billing, she toured with the Military Octette as their conductor and virtuoso cornet soloist. This tour was arranged for her by the Rolfe and Lasky booking agency. ${ }^{62}$

Keith married John Leick, a cornetist and bandmaster, in a ceremony held at the C. G. Conn Factory in Elkhart. Performing as a cornet duo, they made seven European tours, the highlight performance being for the coronation of King George in 1911. Returning to the United States, they both conducted bands in Nebraska until they moved to Denver, Colorado. There they performed with the Denver Municipal Band under the direction of Al Sweet and Frederick Neil Innes. Mrs. Leick taught at Denver University, and directed the first DeMolay Band. She passed away in 1961 in Denver. ${ }^{63}$

\footnotetext{
60 "Melody Lane," The New York Clipper, 31 July 1918 (Old Fulton NY Post Cards).

${ }^{61}$ Pioneers in Brass, used with permission.

${ }^{62}$ Bridges, Pioneers in Brass.

${ }^{63}$ Ibid.
} 


\section{Marie McNeil}

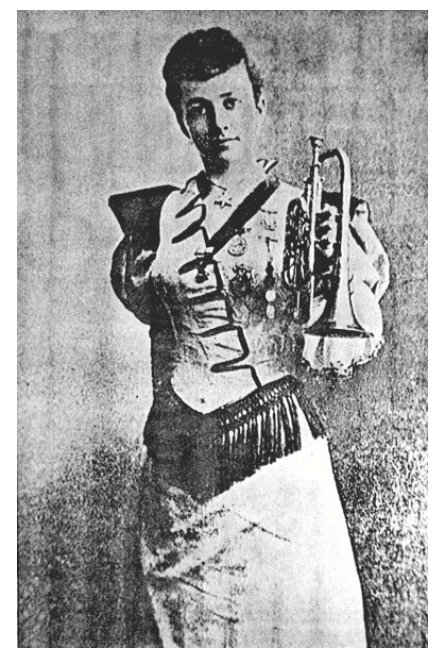

Figure 4. Marie McNeil ${ }^{64}$

Marie McNeil, also referred to in some sources as "Mary" McNeil, was known for her solo performances as well as those given with Anton H. Knoll, Jr. Her solo appearances included a sixteen-week tour with the Elks Carnival Company in $1899 .^{65}$ The Salem Gazette (1905) reported that she was to appear with the vaudeville troupe known as the Fenberg Stock Company in Salem, Massachusetts. ${ }^{66}$

The Knoll and McNeil cornet duo toured the United States giving concerts of music selected from their three-hundred-piece repertoire. For some works, they played two cornets each, at the same time, for a total of four parts. Their pictures can be seen on the cover of the sheet music to "Hearts," a song by Charles K. Harris. The publication states, "Played with great success by the World's Famous Cornet Duettists and Soloists, Knoll and McNeil., ${ }^{67}$ In August 1899, Knoll and McNeil were made honorary members of the Detroit Local Musicians Protective Union No. 5. Together, they performed at the Spokane, Washington Exposition in October 1899 with the Grand Army Band of Canton, Ohio. They were a featured act at the 1912 Panama Exhibition. Both musicians performed on the C.G. Conn New York Wonder Cornet. ${ }^{68}$

A letter written by Knoll and McNeil in 1899 is held in the Western Maryland Historical Library (WHILBR) digital collection. The letterhead identifies them as "Knoll \& McNeil, America's Famous Cornet Duettists and Soloists, Permanent Address, Erie, PA.” Their individual pictures are included in the upper corners with press notices printed down both sides of the document. The handwritten portion of the letter is a response to a request for an

\footnotetext{
${ }^{64}$ Pioneers in Brass, used with permission.

${ }^{65}$ Schwartz, "The Cornet Compendium."

66 "Centuries ago in the Gazette: Salem, 1905," Salem Gazette, 17 November 2005 from Wicked Local Gazette, http://www.wickedlocal.com/salem/archive (accessed February 10, 2009).

67 “American Popular Song Sheet Covers: 1890-1922,” New York Public Library Digital Gallery, http://digitalgallery.nypl.org (accessed February 10, 2009).

${ }^{68}$ Schwartz, "The Cornet Compendium."
} 
engagement to perform as part of a Centennial Celebration, which they had to decline due to their engagement at the Mechanic's Exposition. Several of the press notices printed on the letterhead appear as follows:

Miss Marie McNeil's Cornet Solo was simply superb. With apparent ease, she mastered the most difficult selections, and fully merited the enthusiastic applause received. She stands in the front rank of Lady Cornetists. - Wichita News

Marie McNeil's cornet solos are absolute revelation. She is considered by everyone that has heard her the absolute mistress of this instrument. She is certainly the Queen of the Cornet and has a most charming stage presence. Her marvelous work on the instrument is greatly appreciated and her playing would excite the admiration of Levy. -Chicago Sporting Journal

The make-up of the show is much changed since its' [sic] last visit here, and now includes Marie McNeil, a comely young lady and an expert cornet soloist. -New York Clipper

Among the gems of last Thursday afternoon's concert was: The Cornet Duo by Mr. Knoll and Miss McNeil. The theme was an old and simple one entitled "Swiss Boy." The variations were artistic and added another deserved laurel to the wreath, which these eminent performers are entwining above their brows. On a recall, they gave the old familiar air "Old Log Cabin in the Lane." This also called out prolonged applause, to which they responded by playing "Those Endearing Charms." This again was too much for the audience, who grew enthusiastic, and they again played "Only a Picture," and then the audience, like "Oliver Twist," was asking for more. -Daily Saratogian, Saratoga, NY

Mr. Knoll and Miss McNeil's skill as Cornet Duettists has become a household word, and their appearance upon the stage elicits loud, prolonged applause. Those who have not heard the masters of this instrument can have no idea of its power. In the hands of Mr. Knoll and Miss McNeil the listener is captivated by a yielding pianissimo and insensibly carried through a maize of brilliant passages when the artists assume absolute control of the mind and leads it at will through many pleasing and fantastic scenes. Space does not permit a scientific criticism, which alone can justly compliment America's greatest virtuosos. -Daily Union, Saratoga, NY ${ }^{69}$

The Daily Alta (California) printed the performance program for the Mechanic's Fair in the September 19, 1889 edition. The program indicates that McNeil performed a solo in both the afternoon and evening concerts. Knoll performed a solo in the evening concert, and they both performed together in the afternoon. McNeil retired some time after 1912. Knoll continued to perform on his own, at least until August $1925 .^{70}$

\footnotetext{
69 "Cornetists Knoll \& McNeil," Western Maryland's Historical Library, http://www.whilbr.org/itemdetail.aspx?idEntry=3628 (accessed February 22, 2009).

${ }^{70}$ Schwartz, "The Cornet Compendium."
} 


\section{Florence Louise Horne}

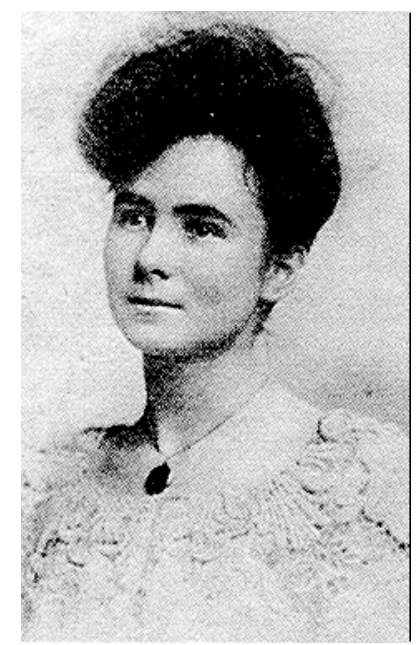

Figure 5. Florence Louise Horne ${ }^{71}$

Born in Cambridge, Maine on April 19, 1880, Florence Louise Horne performed for the Governor's Day Encampment of the National Grand Army of the Republic in Newport, Maine when she was ten years old. At the age of twelve, she began studying formally with Robert Browne Hall in Waterville, Maine, and then appeared as cornet soloist with his Military Band when she was thirteen. She continued to study with Hall until 1896 when she began lessons with Henry C. Brown. ${ }^{72}$ Hall was a march composer and dedicated his composition "The Commander" to his student. ${ }^{73}$

Horne joined the Boston Fadettes Ladies' Orchestra for a season in 1897. In 1898 she toured with the Cecilia Musical Club and by 1900 was performing solo engagements throughout the Midwest. When she was not touring, she also taught cornet lessons. She appeared as a soloist in Norumbega Park in Boston during the summer of 1899, with the U.S. Ladies Military Band of Providence in 1901, with the Tuxedo Ladies Band of Chester Park in Cincinnati, with Miss Reno Mario and her Orchestra at Symphony Hall in Boston in 1906, with the Twelve Navajo Girls at the Atlantic City Pier in 1908, and at the Waldorf-Astoria Hotel in New York City. She was a featured soloist with the Navassar Band and performed with them at Electric Park in Kansas City, Riverview Park in Chicago, and Fairbanks Park in Indianapolis. When Horne retired from the Navassar band, Mabel Keith took her place. Horne married Edmund Stilwell in 1910, gave up touring, and settled in Kansas City, Kansas, where she continued to teach music. She died September $6,1956 .^{74}$

\footnotetext{
${ }^{71}$ Pioneers in Brass, used with permission.

${ }^{72}$ Bridges, Pioneers in Brass.

${ }^{73}$ Allen Graffam, "R. B. Hall Marches," http://www.mta75.org/curriculum/music/rbh/marchlist.html (accessed January 30, 2009).

${ }^{74}$ Bridges, Pioneers in Brass.
} 


\section{Browne Greaton}

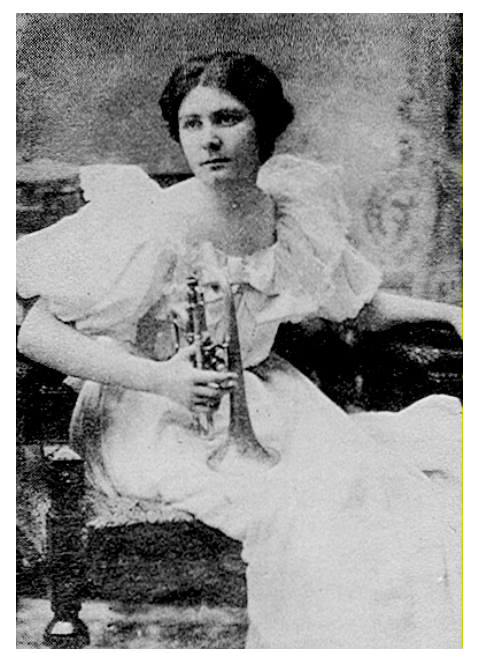

Figure 6. Browne "Brownie" Greaton ${ }^{75}$

Browne "Brownie" Greaton was also known as a virtuoso cornetist. Born in New Richmond, Wisconsin in 1876, she was described as having a beautiful tone and was noted for the brilliance of her triple tonguing. It was said that Herbert L. Clarke praised her playing ability ${ }^{76}$ In 1892, at sixteen years of age, she appeared as a cornet soloist with the Clara Schumann Orchestra. After marrying Mr. Cole in 1898, she retired to Florida to raise a family and spent the rest of her career working in public school music. In 1922, she organized a school band in Ocala, the first in the state of Florida. Her work with the development of public school band programs earned her the designation as "Mother of Florida School Bands." She retired from teaching in 1944 and died in Ocala on August 26, 1956. ${ }^{77}$

\section{Lora Antoinette Reiter}

As mentioned previously, Lora Antoinette Reiter was a cornet soloist with the American Ladies' Grand Concert Band and served as directress for at least one season. A review in Musical America stated, "Her command of expression is wonderful; her playing brilliant and individual." It was reported in the London Times that, "The rarity of a lady cornetist who has really mastered the very difficult technique of the instrument and the temperamental feeling and taste of her playing earned her much enthusiasm from a large audience." The Cedar Rapids Daily Republican described Reiter as "a real artist and her fine playing, together with a pleasing personality, won her a host of friends who will be eager for her appearance in succeeding concerts. ${ }^{, 78}$

\footnotetext{
${ }^{75}$ Pioneers in Brass, used with permission.

${ }^{76}$ Wilma Forwe, “A Woman I Would Like to Know: Browne Greaton Cole," Ocala Outlook 7, no. 11 (May 2008): 5.

${ }^{77}$ Bridges, Pioneers in Brass.

78 "American Ladies Grand Concert Band."
} 


\section{The Minstrel Performers}

In "The African American Contribution to the Cornet of the Nineteenth Century: Some Long-Lost Names," Richard Schwartz identifies the minstrel show as "arguably the most significant performing vehicle" for African American cornet players prior to the twentieth century. A typical day for a minstrel cornetist could be quite laborious, beginning with a morning parade through the main streets of a town performing standard marches by composers such as William Paris Chambers, Charles Lloyd Barnhouse, Robert Browne Hall, or John Philip Sousa. Once arriving at the town square, the company would perform a concert of standard band literature, transcriptions of orchestral music, and arrangements of popular melodies. Following this performance, the group would proceed to the performance hall and then take a break before the evening show. Prior to the show, performances were given outside the hall to draw in the audience and then, during the evening performance, the instrumentalists accompanied all of the solo, ensemble, and specialty acts, in addition to performing their own featured concert pieces. ${ }^{79}$

The Indianapolis Freeman, the first African American illustrated newspaper, was considered to be one of the leading black journals during the late 1800 s. Founded in 1888 , it remains a source of information for scholars interested in learning about various aspects of black culture and includes reportage on black entertainment. ${ }^{80}$ One such report provides information on Mattie Simpson, who performed as a cornet soloist with the Mahara Minstrels in the late 1890s. She appeared on a daily basis in the parades and did solo work during the evening concerts. ${ }^{81}$ Carrie Melvin performed with Professor Henderson Smith's "superb military band" in November 1896. She was the wife of the minstrel Sam Lucas, and was "a splendid musician, [who] rendered difficult selections." 82

Laura Edwards Prampin toured the vaudeville circuit with her husband Harry Prampin and as part of several different minstrel troupes. Their cornet/comedy duo was billed as "The Prampins: High-Class Entertainers." Their publicity ad pictures Laura Prampin in formal attire as the "straight man" to Harry Prampin's "funny man" dressed in a clown outfit. Ms. Prampin was the cornet virtuoso of the team and considered by some to be "the greatest colored lady cornet soloist." 83

The Prampins performed with the Rusco and Holland Minstrels in 1900 and the George and Hart's Minstrel Extravaganza in early 1901. In the spring of 1902, Laura Prampin appeared as a cornet soloist at Crystal Grotto in Madison, Wisconsin. That following summer, the duo traveled with Howe's Great London Circus with Harry Prampin conducting and Laura Prampin appearing as cornet soloist with one of the concert bands. She also performed as a special soloist "accompanied by the big white band," one of the two all-white bands of the circus. The duo

\footnotetext{
${ }^{79}$ Richard I. Schwartz, "The African American Contribution to the Cornet of the Nineteenth Century: Some Long-Lost Names," Historic Brass Society Journal 12 (2000): 62-3.

80 "Jim Crow Press: Indiana," http://www.jimcrowhistory.org/scripts/jimcrow/press.cgi?state=Indiana (accessed January 4, 2009).

${ }^{81}$ Handy, Black Women in American Bands and Orchestras, 164.

${ }^{82}$ Ibid.

${ }^{83}$ Schwartz, "The African American Contribution to the Cornet of the Nineteenth Century," 67-8.
} 
toured California in 1904 and 1905, giving performances in San Francisco, Stockton, and Sacramento. They also performed in Ogden (Utah), Akron (Ohio), and New York City. ${ }^{84}$

Another husband/wife cornet duo was Etta Minor and Frank Clermont. Billed as The Clermonts, records indicate that they toured the United States in 1905. Following the tour, they joined the 14 Black Hussars vaudeville act and toured with them in 1906. The Clermont and Minor act was advertised for the Peking and Monogram Theatres in Chicago in 1912. Clermont passed away in 1913 in New York City. Minor most likely retired from the theatre following her husband's death. ${ }^{85}$

\footnotetext{
${ }^{84}$ Ibid., 68-70.

${ }^{85}$ Ibid., 75.
} 


\section{Chapter 3 - Women's Ensembles and the Transition from Cornet to Trumpet}

\section{Women's Orchestras}

As the impetus of the professional band movement began to slow in the early twentieth century, the professional orchestras became more established. The term "orchestra" was associated with high culture, and was used to describe a variety of ensembles including the "elite art" ensembles that performed the standard orchestral repertoire, the vaudeville-style entertainment orchestras that performed a mix of classics and lighter music, and the jazz orchestras or big bands that performed the popular sweet and swing styles of music. What most of these ensembles had in common was the use of strings. The addition of strings reduced the need to have large wind sections. Where the standard concert band cornet/trumpet section would use five to seven players, the newly formed orchestras used only two to four players, thus making it more competitive to obtain those positions..

At first, orchestral development was centered mostly in the urban areas of the country. America's first "professional" orchestra, the Philharmonic Society of New York (later renamed the New York Philharmonic) was established in 1842. It began as an organized group from which members received equal shares of the revenue generated from concerts. In 1901, musicians began receiving regular salaries. By 1900, four other American cities had orchestras that seemed to have established long-term stability: Boston, Chicago, Cincinnati and Pittsburgh. Other orchestras that were established, but had not developed permanency, were in St. Louis, San Francisco, and Los Angeles. ${ }^{1}$ In the 1920's, performers in these organizations were primarily European-born men. Conductors looked to Europe when wanting to fill vacant positions, which made it difficult for even men born and trained in the United States to obtain work. In 1920, two graduate-level training orchestras (the American Orchestral Society in New York and the Civic Orchestra in Chicago) were established to help open membership in major symphonies to more Americans. ${ }^{2}$ It was not common, at this time, for men and women to perform in musical ensembles together, just as it was not common for whites and blacks to perform together. In December 1878, the Boston Herald reported the "novel occurrence" that a new orchestra in Louisville was opening positions to several female string players and a cornetist. ${ }^{3}$

Christine Ammer, in Unsung: History of Women in American Music, states that the major reason women were excluded from the contemporary orchestras was economic. A position given to a woman was one less job for a man yet, at the same time, conservatories and universities continued to train and graduate women instrumentalists in increasing numbers. ${ }^{4}$ These women left school with the goal of obtaining professional performing positions, and due to relatively few options, some began to form their own orchestras and chamber ensembles. ${ }^{5}$

\footnotetext{
${ }^{1}$ Handy, Black Women in American Bands and Orchestras, 3.

${ }^{2}$ Bowers and Tick, Women Making Music: The Western Art Tradition, 1150-1950, 350.

${ }^{3}$ Ammer, Unsung, 99.

${ }^{4}$ Ibid.

${ }^{5}$ Bowers and Tick, Women Making Music: The Western Art Tradition, 1150-1950, 8.
} 
Ammer places the women's orchestras of the late nineteenth century into three categories: paid professional, unpaid amateur, and semiprofessional. There were several of all three types centered in Boston and New York. One example was the Beacon Orchestral Club of Boston, an amateur group, which included two cornets along with a trombone, flute, clarinet, piano, and strings. Another group, the Englesbian Orchestra of Boston, featured cornetist Lizzie Howe along with a solo cellist in a performance given at the Brookline Town Hall on January 24, $1888 .^{6}$

At first, many of the women's orchestras were looked upon with disdain by the music establishment because many of those in and around New York and Boston were touring and performing in theatres and beer gardens. Female itinerant musicians were looked down upon because of their lifestyle. Instead of being home respectably raising a family, they were riding trains to different cities, staying in strange hotels, rehearsing at odd hours, and performing on stage.

In order to separate themselves from the burlesque style entertainers, the "elite art" ensembles would market themselves in ways that reflected a higher social status and level of professionalism. An example of such was the Eichberg Lady Orchestra from Boston, comprised of women who were from "good families." This distinction was made clear in their publicity brochures and their concert reviews. ${ }^{7}$ The unspoken message was that young musicians from good families had money for formal musical training that allowed them to become more proficient and able to produce music of a better quality. Another way they distinguished themselves was by wearing formal, feminine dress. ${ }^{8}$

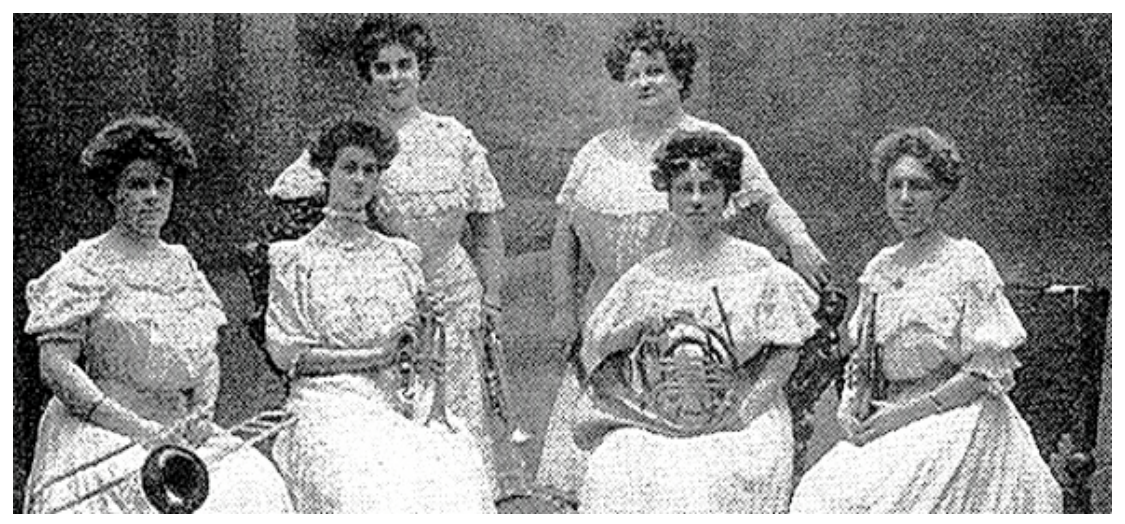

Figure 7. Boston Fadettes Women's Orchestra Brass Section'

The most prominently known professional women's group during the turn of the century was the Boston Fadettes Women's Orchestra. Founded in 1888 by conductor Caroline Nichols, this group performed extensively throughout the United States and Canada until 1920. Nichols organized the group for the purpose of creating an employment opportunity for herself and other

\footnotetext{
${ }^{6}$ Ammer, Unsung, 104.

${ }^{7}$ Dempf, "All-Women Orchestras in the United States," 15.

${ }^{8}$ Beth MacLeod, "Whence comes the Lady Tympanist?: Women and Musical Instruments in America"

The Maud Powell Signature 1, no. 3 (Winter 1996): 26.

${ }^{9}$ Pioneers in Brass, used with permission.
} 
female musicians. The ensemble performed a repertoire of over six hundred pieces, including "symphonies, all of the classical overtures, selections from seventy-five grand operas, and numerous salon pieces and popular songs." musicians when on tour, two of whom were cornet players. The Fadette program book helped to reinforce its "respectable" status:

The personal attractiveness, good character, and musical ability of the members had made for them many friends, and secured the support of the better class of music-lovers; they had all the engagements they could fill, and their lines lay in pleasant places as well. Their home city, known around the world for its exclusiveness, was proud of them, and they met, and met adequately, the demands of the music business in the grand old Commonwealth. $^{11}$

During the summer of 1902, a larger group of forty Fadettes performed at B. F. Keith's theatre in Boston. They ensemble performed so well that it was contracted for the entire summer booking, displacing some members of the Boston Symphony Orchestra, and causing a rift in the symphony. Many of the Fadettes were students of symphony members, and other orchestra personnel blamed their colleagues for the loss of work. The Fadettes' success that summer was so great that Keith hired them to perform on his winter circuit, in the more respectable vaudeville theaters across the United States. The ensemble continued to tour on the Keith circuit from 1902 through $1917 .^{12}$ It directly and successfully competed with the professional men's ensembles, performing 3,050 concerts in vaudeville theatres and 2,025 concerts in parks and summer resorts. ${ }^{13}$ The Fadettes shared the bandstand with the John Philip Sousa Band, the Giuseppe Creatore Band, and the Walter Damrosch Orchestra at the Exposition in Pittsburgh in 1902 and 1903. ${ }^{14}$ Backhaus lists thirty different cornetists who performed as part of the group. (see Table 3).

Table 3. Cornetists with the Fadettes Woman's Orchestra ${ }^{15}$

\begin{tabular}{|c|c|c|}
\hline Arey, Gladys & Gulesian, Ida & Sawyer, Lillian \\
\hline Batchelder, Alice & Harris, Olive & Shipley, Mabel \\
\hline Boardman, Bertha & Howe, Lizzie & Silsby, Bertha \\
\hline Brown, Hazel & Leighton, Clara & Stevens, Frances \\
\hline Buckley, Dorothy & Levy, Annie White & Stiles, Bertha \\
\hline Caldwell, Edith & Martin, Wealthy & Tilken, Freda \\
\hline Carpenter, Eva & Munroe, Daisy & Timayenis, Alfreda \\
\hline Clifford, Marion & O'Toole, Helen & Virgin, Velma \\
\hline Damon, Dora & Rosenberg, Lillian Bowers & Young, Fannie E. \\
\hline Gooding, Grace M. & Saunders, Eleanor & Youngman, Elizabeth Banks \\
\hline \multicolumn{3}{|c|}{$\begin{array}{l}{ }^{10} \text { Ammer, Unsung, } 105 . \\
11 \text { "The Fadettes Woman's Orchestra of Boston," Redpath Chautauqua Collection, University of Iowa } \\
\text { Libraries Special Collections Department, http://sdrcdata.lib.uiowa.edu/libsdrc/details.jsp?id=/fadettes/1 } \\
\text { (accessed January 10, 2009). } \\
{ }^{12} \text { Dempf, "All-Women Orchestras in the United States," } 16 . \\
{ }^{13} \text { Ammer, Unsung, } 106 . \\
{ }^{14} \text { Dempf, "All-Women Orchestras in the United States," } 16 . \\
{ }^{15} \text { Backhaus, "Source Guide for Research on Women Instrumentalists." }\end{array}$} \\
\hline
\end{tabular}


Another "respectable" touring ladies' ensemble was the Pittsburgh Ladies Orchestra. Founded and directed by Mr. A.D. Liefeld, the group was active from 1911 until (at least) 1923. The instrumentation of the ensemble ranged from six to eleven members. The smaller ensembles included one lady cornetist, while the larger had two cornetists and a trombonist as well. A featured member was Liefeld's son, twelve-year old Master Theodore S. Liefeld, Trumpet Soloist and Clever Trap-Drummer. ${ }^{16}$ The orchestra toured in nineteen states, performing for church assemblies and park concerts, including a performance before an audience of five thousand at the Nineteenth Session State Epworth Assembly in Lincoln, Nebraska, and a threemonth engagement on the Chautauqua Tour of the New England states. The ensemble's program consisted of vocal and instrumental pieces of both classical and popular numbers, including original compositions by Liefeld. Reviews printed in its publicity material provide further insight into how the group was received: ${ }^{17}$

It is such work that raises the musical standards of the time, and the conductor, A.D. Liefeld, who is also a composer of merit, is to be congratulated upon the results he obtained. - Syracuse Journal

I have heard the Pittsburgh Ladies Orchestra with great appreciation and delight. Albert D. Liefeld, as conductor, is the personification of delicate and soulful interpretation. He and the ladies of the orchestra evidently work under high ideals and worthy motives. One arises from the privilege of their concert work refreshed, satisfied and inspired. Long live the P. L. O. - Bishop William M. Bell, Los Angeles, CA ${ }^{18}$

Quite a few other ladies' orchestras provided performance opportunities for trained cornetists. The Saturday Morning Orchestra in San Francisco was in existence in the 1890s and carried twenty-six players including three cornets. The Cleveland Ladies' Orchestra performed daily concerts of light repertoire at the Atlantic City Royal Palace Hotel during the summer of 1900. The Women's Philharmonic Society of New York was founded in 1899 and supported an all-women's orchestra among other musical groups. The group performed four large concerts each season along with monthly musicales. It was still performing in 1916 and had several cornets, although no trombones or tubas. ${ }^{19}$

Black female musicians also banded together to form their own ensembles. Madam Corilla Rochon led a ladies' Symphony Orchestra in Houston Texas between 1915 and 1920. This ensemble had several wind players including E. M. Johnson and B. F. Barlow on cornet. Cambridge was home to the Female Symphony and New Orleans had the Nickerson Ladies' Orchestra. ${ }^{20}$ Miss May Moore from Cleveland, Ohio was reported to have a small orchestra that

\footnotetext{
16 "Pittsburgh Ladies Orchestra: A Company of High Class Entertainers - Vocal and Instrumental," Redpath Chautauqua Collection, University of Iowa Libraries Special Collections Department, http://sdrcdata.lib.uiowa.edu/libsdrc/details.jsp?id=/pittsburghl/1 (accessed January 10, 2009).

${ }^{17}$ Ibid.

${ }^{18}$ Ibid.

${ }^{19}$ Ammer, Unsung, 107.

${ }^{20}$ Handy, Black Women in American Bands and Orchestras, 169. Note: There is no indication in the source which state was home to the Female Symphony of Cambridge.
} 
included piano, violin, cornet, and drum. ${ }^{21}$ Trumpeters Thelma Tibbs and Sarah Brooks performed with the Poro College Ladies' Orchestra, also during the 1920s in St. Louis. ${ }^{22}$

A vaudeville-style orchestra that was organized to provide employment for black female musicians in New York was the Ladies Orchestra. Under the direction of Marie Lucas, conductor and trombonist, the ensemble performed at the Lafayette Theatre beginning in 1914, and became a permanent fixture in 1915. The orchestra performed a program that was a mixture of classical and popular selections favored on the vaudeville circuit. ${ }^{23}$

There were several all-black symphonic-style orchestras in operation during the early part of the twentieth century including the New Orleans Philharmonic Society (c. 1860), Philharmonic Society of New York (1876), the Progressive Musical Union of Boston (c. 1875), the Philadelphia Concert Orchestra (1905), Boston's Victorian Concert Orchestra (1906), the Orchestra Association of Philadelphia (1907), and the Baltimore City Colored Orchestra (1929). Although these groups were mostly male, they did have some female membership. ${ }^{24}$

Robert E. Giles conducted a community orchestra in Chicago during the 1920s that included Gertrude Irene Howard (Harrison) on cornet. Howard, a graduate of Chicago Musical College, also performed with the Chicago Colored Women's Band and in N. Clark Smith's (twenty-four piece) Ladies Orchestra. ${ }^{25}$ The Freemen published a photograph of Irene Howard, presumably the same person, indicating that she sang, played cornet and included a bit of comedy in her act at New Crown Garden in Indianapolis, Indiana. She performed a tripletongued solo as well as a ragtime piece on her gold cornet. This was not her first performance there, because the newspaper reported a change in her costume and selections from previous appearances. $^{26}$

The first women's symphony that grew to full symphonic size was the Los Angeles Women's Symphony, founded in 1893. Like most start-up groups, it began small, with twentyfive players, and performed the lighter repertoire. ${ }^{27}$ As the ensemble developed, it began playing symphonies and other classical works. By 1907, the ensemble succeeded in populating the wind, brass, and percussion sections with female players. ${ }^{28}$ This was quite an accomplishment given that many of the early women's orchestras had to rely on male performers to play the instruments not commonly played by women. Over time, skill levels developed and by 1936, membership was at seventy players. The group consisted of amateurs and professionals alike, allowing the opportunity for all the women to become proficient at playing the symphonic repertoire. ${ }^{29}$

\footnotetext{
${ }^{21}$ Ibid., 40.

${ }^{22}$ Ibid., 169.

${ }^{23}$ Ibid., 40.

${ }^{24}$ D. Antoinette Handy, "Black Women and American Symphony Orchestras," The Maud Powell

Signature 1, no. 3 (Winter 1996): 21.

${ }^{25}$ Schwartz, "The Cornet Compendium."

${ }^{26}$ Ibid.

${ }^{27}$ Ammer, Unsung, 106-7.

${ }^{28}$ Dempf, "All-Women Orchestras in the United States," 26.

${ }^{29}$ Ammer, Unsung, 106-7.
} 
During the interwar period, an estimated thirty full-sized women's symphonies flourished across the United States. These orchestras were similar to the professional men's ensembles in that they performed standard orchestral repertoire and a standard seasonal schedule. Most of these ensembles were founded by a local instrumentalist or conductor for the purpose of creating performance opportunities for professional female musicians. ${ }^{30}$ One example, the Women's Symphony of Philadelphia, conducted by J. W. F. Leman, was founded in 1921 by trumpeter Mabel Swint Ewer, who was a graduate of the New England Conservatory. Ewer had performed in the Conservatory orchestra under the baton of George W. Chadwick, and also in brass ensembles in the Philadelphia and New England areas. ${ }^{31}$

Another example was the Boston Women's Symphony, established by Ethel Leginska. The orchestra gave an initial concert on March 23, 1927 and then its first "real" concert on December 12. The ensemble often performed compositions by female composers including Radie Britain's "Symphonic Intermezzo," Ethel Leginska's "Tryptich" for eleven solo instruments and her "Fantasie" for piano and orchestra, and Mabel Wood Hill's arrangement of a Bach Prelude and Fugue for strings. During the second season, the group toured for six weeks in Chicago, St. Louis, Milwaukee, Buffalo, Cleveland, and Washington, D.C., giving fifty-two programs in thirty-eight cities. ${ }^{32}$ The following season, the ensemble toured seventy-five cities. Both tours provided great exposure for the female performers, and demonstrated to innumerable women that orchestral instrumental performance was acceptable for both men and women. Performances included such orchestral standards as Beethoven's Symphony no. 5 in C minor, the Mendelssohn Piano Concerto no. 1 in G minor, the overtures to Rienzi and Die Meistersinger, Schubert's Symphony no. 8 in B minor, Liszt's Les Préludes and Hungarian Fantasia to name a few. The orchestra's final concert was given on January $29,1930 .^{33}$

In 1932, Leginska formed a new women's orchestra called the National Women's Symphony (also known as the Women's Symphony), which was based in New York City. The initial concert included Schubert's Symphony in B-flat, Glinka's Overture to Ruslan and Lyudmila, and the Mozart Piano Concerto in A major. The ensemble was well received but disbanded soon after that first concert. ${ }^{34}$

Conductor Frederique Petrides founded the Orchestrette of New York along with pianist/composer Julia Smith in 1932. This ensemble began with thirty to forty players who were graduates of the Julliard Conservatory, the Curtis Institute, and the Eastman School of Music. Petrides' goal was not to promote the idea of a women's orchestra; rather, she viewed the Orchestrette as a stepping-stone towards her ultimate goal, the mixed orchestra. She wanted to prove that women could perform as well as teach. The Orchestrette gave five or six concerts per season in the Carnegie Recital Hall, and promoted American music by performing works by David Diamond, Norman Dello Joio, Aaron Copland, and Samuel Barber among others. Petrides

\footnotetext{
${ }^{30}$ Carol Neuls-Bates, "Women's Orchestras in the United States, 1925-45," in Women Making Music: Studies in the Social History of Women Musicians and Composers, ed. Jane Bowers and Judith Tick (Berkeley, CA: University of California Press, 1982), 350.

${ }^{31}$ Neuls-Bates, "Women's Orchestras in the United States," 353.

${ }^{32}$ Ammer, Unsung, 111.

${ }^{33}$ Neuls-Bates, “Women's Orchestras in the United States,” 357-8.

${ }^{34}$ Ammer, Unsung, 111.
} 
believed in the abilities of her players, and attributed the 1943 disbanding of the group to the fact that they were able to obtain positions in major orchestras, filling vacancies created by men called up in the draft. She also indicated that "at the time, the idea of preserving and fighting for a women's orchestra seemed so insignificant in the face of a world war and the daily reports of the many terrible tragedies." ${ }^{35}$ In essence, she did achieve her goal of providing performance experiences to her musicians that enabled some of them to obtain positions in mixed orchestras.

Also working towards orchestra integration was Antonio Brico and the New York Women's Symphony Orchestra, who gave their first concert on February 18, 1935 at Carnegie Hall. Brico believed "If nine women can play together, then why not ninety?"36 The eighty-sixpiece ensemble received excellent reviews for performances of Schumann's Symphony no. 1 in B-flat major, Handel's Concerto Grosso in D minor, and Tchaikovsky's Romeo and Juliet overture. It performed two more concerts that season, and a full season at Carnegie Hall the following year. In 1938, Brico integrated the ensemble by hiring ten men. She believed that she had proven her point that women could play as competently as men and, therefore, should play with men. Her board of directors did not agree with her, and she speculated that the reason was because the novelty aspect of the ensemble was no longer present. Unfortunately, the orchestra did not survive much longer despite enthusiastic reviews of its concerts. ${ }^{37}$

Women's orchestras continued to be a viable option for female performers unable to obtain positions in the major symphony orchestras. Ammer indicates that by 1936, there were five hundred twenty-two women performing in eight women's orchestras. ${ }^{38}$ Neuls-Bates reports sixteen women's orchestras with over nine hundred players in $1938 .^{39}$

One of the largest orchestras at this time was the Women's Symphony of Long Beach (California). ${ }^{40}$ Backhaus lists eighteen trumpet/cornet players who performed during the tenure of the ensemble (see Table 4). Petrides provided a description of the ensemble in a progress report she published as part of her newsletter, Women in Music, on July 20, 1935:

The Long Beach Woman's Orchestra was organized in 1925. There are 102 experienced players in its ranks now, and plans for the coming season include the addition of about 25 more members to the personnel. Its record includes more than 100 public concerts, also participation in over 1000 programs through its various ensemble units.

\footnotetext{
${ }^{35}$ Carol Neuls-Bates, ed., Women in Music: An Anthology of Source Readings from the Middle Ages to the Present, (New York: Harper and Row Publishers, 1982), 260-3.

${ }^{36}$ Ibid., 256.

${ }^{37}$ Ammer, Unsung, 112.

${ }^{38}$ Ibid., 111, 106-7.

${ }^{39}$ Carol Neuls-Bates, “Women's Orchestras in the United States,” 363.

${ }^{40}$ Ammer, Unsung, 106-7.
} 
Table 4. Trumpeters with the Long Beach Women's Symphony Orchestra ${ }^{41}$

\begin{tabular}{|c|c|c|}
\hline Performer & Decade & Notes \\
\hline Anspach, Mary Jo & 1930 & \\
\hline Armstrong, Allene & 1930 & cornetist \\
\hline Bergey, Frances & 1930 & \\
\hline Brown, Ila Mae & 1930 & \\
\hline Hensley, Ilamae & 1930 & $\begin{array}{l}\text { Performed in Central America and in Europe with an ensemble } \\
\text { known as the Ingenues. }\end{array}$ \\
\hline Hensley, Isabella & 1930 & \\
\hline Howard, Verda & 1930 & \\
\hline Jones, Virginia & 1930 & cornetist \\
\hline Klingaman, Gertrude & 1930 & from Goshen, Indiana. \\
\hline Krueger, Doris & 1930 & Also played with the Los Angeles Women's Symphony. \\
\hline McCormick, Carol & 1930 & \\
\hline Melton, Marilyn & 1940 & $\begin{array}{l}\text { The granddaughter of Ida May Melton. Born in Long Beach, } \\
\text { CA. Her father was a trombonist of some fame: Marston } \\
\text { Melton. }\end{array}$ \\
\hline \multicolumn{3}{|l|}{ Revis, Ruth } \\
\hline Scruggs, Pauline & 1930 & Attended college at Long Beach City College. \\
\hline \multicolumn{3}{|l|}{ Thurlo, Emma } \\
\hline \multicolumn{3}{|l|}{ Van Houten, Betty } \\
\hline Williams, Doris & 1930 & \\
\hline Wyatt, Marilyn & & \\
\hline
\end{tabular}

The Women's Symphony Orchestra of Chicago was another of the largest and wellestablished women's orchestras, with over one hundred players. Founded in 1924, the ensemble performed subscription concerts for over twenty years until it disbanded in 1947. The orchestra also performed in Grant Park during the summers before audiences of thousands of people, and several of these concerts were broadcast nationally over the radio. The list of works performed includes over four hundred and fifty standard orchestral pieces, covering the Baroque through the Modern eras. ${ }^{42}$

These orchestras provided venues for women to learn the standard orchestral repertoire while allowing them opportunity for employment. In most cases, such employment was not fulltime; however, many women were able to take advantage of the opportunity to supplement their other performance income.

In the early 1900s, the professional band movement began to decline while professional orchestras began to flourish. These orchestras primarily hired European-trained men and (to find an avenue to utilize their talents) female musicians played in all-women orchestras or small ensembles, or performed as featured soloists. Recognizing the restrictions of the time and the

\footnotetext{
${ }^{41}$ Ibid.

${ }^{42}$ Linda Dempf, “The Woman's Symphony Orchestra of Chicago," Notes: Quarterly Journal of the Music Library Association 62, no. 4 (June 2006): 872.
} 
limited opportunities for woman musicians, various entrepreneurial female cornetists or trumpeters formed their own orchestras and performing groups. Careful marketing of such groups was extremely important because females participating in this type of activity were often looked down upon. Special attention was made to present the women as educated professionals, and maintaining this impression was important to their initial success. To find the primary reason for the continued success and popularity of these woman's orchestras and performing groups, one has to recognize their excellent musicianship, talent, and organizational skills.

\section{The Soloists}

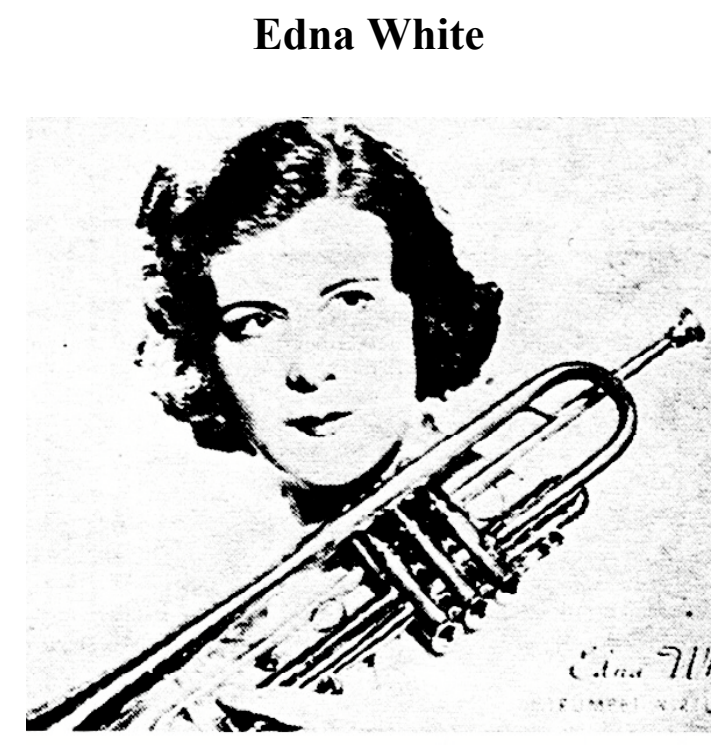

Figure 8. Edna White ${ }^{43}$

Edna White was one woman who performed in several of the all-women orchestras and worked to maintain a professional solo career. White was born in Stamford, Connecticut on October 23, 1892 to parents Herbert John White, an amateur cornetist, and Harriett Linwood Stone. Herbert had wanted a son to carry on the family tradition of cornet playing that had been established by his father but, lacking that son, decided that Edna would have to do. Recognizing her natural ability and need for instruction beyond his abilities, White's father moved the family to Brooklyn, New York to be near better teachers. He joined the Amicitia Band, an amateur group, where Edna was given the opportunity to appear as featured soloist at their Carnegie Hall concert given on May 3, 1902, when she was nine years old. ${ }^{44}$ Seeing the need for a concert promoter, her parents hired Alonzo Foster to represent her, which led to Edna's appearance at the popular Ocean Grove Festival in the summer of 1902 in a venue that seated ten thousand people. She performed as a child soloist there for eight summers. ${ }^{45}$ In an interview she gave to Ralph

\footnotetext{
${ }^{43}$ Pioneers in Brass, used with permission.

${ }^{44}$ Susan Fleet, "Edna White Chandler: A Brasswoman Pioneer," 7.

${ }^{45}$ Ibid., 8.
} 
Dudgeon in 1990, she related that her performance repertoire for those concerts included hymns, airs, and variations. ${ }^{46}$

In 1904, she began study at the Institute of Musical Art, which later became the Julliard School of Music. She studied with Adolphe Dubois, principal trumpet of the New York Philharmonic at that time. Dubois switched her to trumpet, rather than cornet. She was the only graduate to perform at the Institute's commencement in 1907, but received no degree because she was too young, being only fourteen years old. ${ }^{47}$ Dubois taught her from the Arban Complete Conservatory Method for Trumpet, and exercises composed by his former teacher. She believed she was one of the first women to play trumpet rather than cornet. Cornet was considered to be a more ladylike instrument than trumpet. ${ }^{48}$

In 1908, White formed the first of her many professional quartets with sisters Norma and Cora Sauter, and Florence McMillan. She named the group the Aida Quartet and they performed on the Redpath Chautauqua circuit during the 1910-11 season. Norma and Cora Sauter played violin and cello, respectively, while McMillan played piano. The group performed a versatile repertoire of solos and chamber music as well as trumpet quartets and trios (see Tables 5 and 6). White received billing as the Only Woman Solo Trumpeter in the World. In 1910, McMillan had to leave the group and was replaced by Ruth Wolfe. Musical America published the following description of the ensemble: ${ }^{49}$

The novelty of the evening was the playing of the Aida Trumpet Quartette, an organization of four young women whose attractiveness and excellent playing won the audience. The usual blatant qualities of the trumpets were subdued until the tonal effect was soft and delicate, and the appreciation of this fact compelled several numbers to be added on the program.

\footnotetext{
${ }^{46}$ Ralph Dudgeon, “An Interview with Edna White Chandler," International Trumpet Guild Journal 15, no. 2 (December 1990): 5.

${ }^{47}$ Susan Fleet, "Edna White Chandler," 8.

${ }^{48}$ Ralph Dudgeon, "An Interview with Edna White Chandler," 5-8.

49 “Aida Quartette,” Iowa Digital Library, http://digital.lib.uiowa.edu (accessed March 8, 2009).

${ }^{50}$ Ibid.
} 
Table 5. Repertoire lists from Aida Quartet Concert Programs ${ }^{51}$

\begin{tabular}{|c|c|c|}
\hline \multicolumn{3}{|c|}{ 1911-12 Tour } \\
\hline March from Tannhauser & Wagner & Quartet \\
\hline Non pin Audrai from Figaro & Mozart & Mr. Plancon \\
\hline Extase & Gonne & Trio \\
\hline Air and Variations & Hartmann & Miss White \\
\hline Gypsy Dance & Nachez & Miss Sauter \\
\hline Drink to Me Only & Old English & Trumpet Quartet \\
\hline Hunting Song & Weber & Trumpet Quartet \\
\hline Aria from Pagliacci & Leoncavallo & Mr. Plancon \\
\hline Vito & Popper & Miss Cora Sauter \\
\hline Rosary & Nevins & Miss White with Violin Obbligato \\
\hline Spring Song & Becker & Miss White with Violin Obbligato \\
\hline Hungarian Dance & Brahms & Trio \\
\hline March from Aida & Verdi & Trumpet Quartet \\
\hline \multicolumn{3}{|c|}{ 1912-13 Tour ${ }^{52}$} \\
\hline March of the Coronation & Meyerbeer & Quartette \\
\hline Aria from Il Barbiere di Seviglia & Rossini & Mr. Plancon \\
\hline Fantasie & Arban & Miss White \\
\hline Gypsy Dance & Nachez & Miss Sauter \\
\hline My Heart at Thy Dear Voice & Saint- Säens & Trio \\
\hline Partrouille Enfantine & Gillet & Trumpet Quartette \\
\hline Eri Tu from Un Ballo in Maschera & Verdi & Mr. Plancon \\
\hline The Spider & Dunkler & Miss Cora Sauter \\
\hline Carmeva & Nillson & Trumpet Quartette \\
\hline Serenade & Pierne & Trio \\
\hline Spanish Dance & Moszkowski & Trio \\
\hline March from Aida & Verdi & Trumpet Trio with Piano \\
\hline \multicolumn{3}{|c|}{ Date Unknown } \\
\hline Faust Fantasy & Gounod & Mr. Plancon \\
\hline Drink to Me Only with Thine Eyes & Old English & Mr. Plancon \\
\hline The Two Grenadiers & Schumann & Mr. Plancon \\
\hline Hungarian Dances & Brahms & Trio \\
\hline Theme and Variations & De Beriot & Miss White \\
\hline Gypsy Dance & Nachez & Miss Sauter-violin \\
\hline Last Night & Kjerulf & Quartet \\
\hline Hunting Song & Weber & Quartet \\
\hline Traumerai & Schumann & Trio \\
\hline Serenade & Victor Herbert & Trio \\
\hline Air Varie & Arban & Miss White, Miss Wolfe \\
\hline Prologue from Pagliacci & Leoncavallo & Mr. Plancon \\
\hline Vito & Popper & Miss Sauter, cello \\
\hline March Militaire & Navarro & Quartet \\
\hline
\end{tabular}

51 "Aida Quartet"

52 The ensemble disbanded sometime in 1912. The date of this concert program would indicate that possibly this occurred mid-season. 
In order for the members of the Aida Quartet to maintain a respectable reputation, the Redpath Company hired an older gentleman and baritone soloist, C. Pol Plancon, to tour with them. The ensemble traveled by train through Texas, Iowa, Nevada, Nebraska, Kansas, and the Dakotas. ${ }^{53}$ Promoting a highbrow style of performance, the concert publicity program touted the fact that all of the artists were from good families and/or had studied with reputable teachers. The Sauter sisters had an especially sophisticated pedigree:

The Misses Sauter are direct descendants of Franz Wehrberger, Ludwig Jagerhuber and Severin Sauter. Their grandfather, Franz Wehrberger, conducted the grand opera in Trieste, Austria, and brought out several of Verdi's operas under the latter's personal supervision. Ludwig Jagerhuber was a member of Richard Wagner's orchestra as his oboe soloist, and was honored in being numbered among the intimate friends of that famous composer. Severin Sauter was conductor of the court orchestra of the Duke of Hohenzollern. In 1848 he came to America and in St. Louis organized an orchestra where he was at once recognized leader in musical circles as solo violinist and as conductor. ${ }^{54}$

As was common when reviewing female performers, the artists not only had to play well but they had to look attractive as well. A Portsmouth News reviewer was able to look beyond appearance to describe a concert given by the quartet:

Technically the performance of each artist was surprising. The harmonics and double stopping of the Violinist, the skillful rapidity with which the Cellist executed her runs and trills, the clear soul stirring notes of the Trumpeter, the sympathetic work of the Pianist, all showing the rich musical talent and splendid training which should give to each a great career. $^{55}$

Of White's playing, the New York Tribune wrote:

Miss Edna White played "Rhapsodie Heroique" by Armand Raynaud, with orchestral accompaniment. She possesses the technique and accuracy of touch, which is expected of a mature performer, without exhibiting weariness of either mind or body. ${ }^{56}$

The ensemble toured for two seasons and then disbanded in 1912 amidst turmoil in the group. White returned to her parent's home in Indianapolis and after much urging on their part, married her neighbor, Myron Hall Chandler. Her new husband was twenty years her senior, and had served in the Spanish American War and as a foreign service officer in Cuba and the Philippines. He disapproved of her trumpet playing, saying that she was too lovely to play the instrument. He tried to get her to switch to violin or voice, but she refused and insisted they move back to New York so she could resume her career. When the war broke out, they

\footnotetext{
${ }^{53}$ Susan Fleet, "Edna White Chandler," 8-9.

54 “The Aida Quartette and Mr. C. Pol Plancon,” Iowa Digital Library, http://digital.lib.uiowa.edu (accessed March 8, 2009).

55 “The Aida Quartet of New York City,” Iowa Digital Library, http://digital.lib.uiowa.edu (accessed march 8, 2009).

56 “Aida Quartette."
} 
experienced some financial hardships. White founded the Edna White Trumpeters and became the sole financial support for her family for a time. ${ }^{57}$

The Edna White Trumpeters performed as part of the transcontinental telephone demonstration on Brooklyn Day, June 30, 1915. The quartet was on the Brooklyn end of the communication and provided a musical selection that was broadcast across the continent to San Francisco. Louise Gura is mentioned as "the cornet player of the group" who was originally from San Francisco. ${ }^{58}$ As the quartet played over the telephone, they were told by the people in San Francisco that the sound was too strong, so White played the solo, "Darling I am Growing Older." 59 The quartet also performed in San Francisco for evangelist Billy Sunday at the Panama Pacific Exposition during the summer of 1915, at which time White also soloed with the Mexican National Band. ${ }^{60}$

In the fall of 1916, White became pregnant and gave up performing with the Edna White Trumpeters, allowing them to retain the group name. Her replacement in the group was Katherine "Kitty" Rankin. ${ }^{61}$ White separated from Chandler in 1919, and in order to support herself and her son, she started a new quartet, taking back her group name but not the personnel from the still-functioning group, and called it the Edna White Quartet. The instrumentation was again different, consisting of White and Julie Golden on trumpet, and trombonists Velma Howell and Ida Bisbee. During the 1920s, the ensemble toured the Keith vaudeville circuit and vacation resorts. $^{62}$ They had numerous concert dates, a sixteen-week tour for the Redpath Lyceum Bureau, and two thirteen-week commercial broadcasting contracts for WABC. Other personnel that performed with the group included Claire Wheeler and Cora Dexter on trumpet, and Betty Barry of Indianapolis, Indiana on trombone. ${ }^{63}$ Table 6 provides a sample of the quartet's repertoire.

\footnotetext{
${ }^{57}$ Susan Fleet, "Edna White Chandler," 9.

${ }^{58}$ Telephone Review (New York: The New York Telephone Company, 1915), 237.

${ }^{59}$ Ralph Dudgeon, "An Interview with Edna White Chandler," 7.

${ }^{60}$ Susan Fleet, "Edna White Chandler," 9.

${ }^{61}$ Ibid.

${ }^{62}$ Ibid.

63 “Edna White Quartet," Iowa Digital Library, http://digital.lib.uiowa.edu.
} 
Table 6. Edna White Quartette Partial Repertoire List ${ }^{64}$

\begin{tabular}{|c|c|}
\hline \multicolumn{2}{|c|}{ Classic } \\
\hline Andante Cantabile & Tchaikovsky \\
\hline Liebestraume & List \\
\hline Prelude & Rachmaninoff \\
\hline Nocturne & Mendelssohn \\
\hline Liebeslied & Kreisler \\
\hline Pomp and Circumstance & Elgar \\
\hline Pilgrims Chorus & Wager \\
\hline Largo from New World Symphony & Dvorak \\
\hline Minuet & Beethoven \\
\hline Early Spring & Mendelssohn \\
\hline Traumerai & Schumann \\
\hline Serenade & Schubert \\
\hline Lullaby & Mozart \\
\hline Romance & Rubinstein \\
\hline Valse in A major & Brahms \\
\hline Waltz from Copellia & Delibes \\
\hline Cavatina & Raff \\
\hline To a Wild Rose & MacDowell \\
\hline Selections from Madame Butterfly & Puccini \\
\hline Selections from Lohengrin & Wagner \\
\hline Selections from Carmen & Bizet \\
\hline \multicolumn{2}{|c|}{ Popular } \\
\hline Sextette from Lucia & Donizetti \\
\hline Quartette from Rigoletto & Verdi \\
\hline Raymond Overture & Thomas \\
\hline Scherzo & Carbonara \\
\hline Morning, Noon and Night & Suppè \\
\hline Medley & Victor Herbert \\
\hline Kerry Dance & Molloy \\
\hline Bells of St. Mary's & Old English \\
\hline Washington Post & Sousa \\
\hline Barcarolle from Tales of Hoffman & Offenbach \\
\hline I Hear You Calling Me & Marshall \\
\hline Carmena Waltz & Wilson \\
\hline $\begin{array}{l}\text { Sliding Jim \& Serio Comique (Trombone } \\
\text { Novelties) }\end{array}$ & Negro Spirituals \\
\hline $\begin{array}{l}\text { The quartet has also a very lovely sacred re } \\
\text { Handel's Messiah and Gaul's Holy City in }\end{array}$ & $\begin{array}{l}\text { re and is prepared to do the entire scores of } \\
\text { nction with church choirs. }\end{array}$ \\
\hline
\end{tabular}

\footnotetext{
64 “Edna White Trumpeters” Iowa Digital Library, http://digital.lib.uiowa.edu (accessed February 8, 2009).
} 
During the 1920's, White became a recording artist for Edison and Columbia recording companies, and married operatic baritone, Torcum Bazazian. Together they created a successful vaudeville act that toured the United States. In 1927, due to divergent professional paths, the couple separated. She resumed her solo career, as well as her quartet playing, but work became scarce after the 1929 Stock Market Crash. ${ }^{65}$ Vaudeville, which had provided her with a great amount of work, was in decline due to new forms of entertainment including radio and talking pictures.

In the 1930s, White took various free-lance work such as singing soprano with an opera company and serving as an instructor of music and dramatics at a military academy. She played with two all-women orchestras, the New York Women's Symphony conducted by Antonia Brico, and the Boston Women's Symphony conducted by Ethel Leginska. She continued to pursue solo and ensemble work, including a performance of Rimsky Korsakov's "Flight of the Bumblebee" broadcast on the Program Famous Firsts on WOR radio, a 1941 tour with the American Women's Symphoniette, performances with the Tone Weaver's brass quartet in 1942, and a solo performance with the Montreal Women's Symphony in $1944 .{ }^{66}$ When asked to perform as part of an all-girl swing orchestra, she refused. She also refused an offer to play with a circus, because her act was to include riding a white horse while playing her trumpet. ${ }^{67}$

On February 19, 1949, she gave a recital at Carnegie Hall, which was the first solo recital to be given there by a trumpeter, male or female. Along with other selections, she performed the Georges Enesco Légende, and premiered At the Beach, a composition by her friend Virgil Thomson. She received favorable reviews in The New York Herald Tribune, the New York Times, and from Bandmaster Edwin Franco Goldman. Her success opened the doors to new work, including a performance on We the People (a CBS television program), two solo appearances with the Goldman Band in New York, and a thirty-seven week tour of military hospitals. During the 1950s, she performed much less but did premiere the Trumpet Sonata by George Anthiel at Columbia University. She gave a farewell recital in 1957, again at Carnegie Hall, at the age of sixty-five. ${ }^{68}$

White lived to be ninety-nine years old, passing away on June 25, 1992. During her retirement, she spent much of her time writing newspaper and magazine columns, working in public relations and as a magazine editor, and writing poetry. She also composed a Suite for Solo Trumpet and Orchestra, which was premiered February 9, 1980 by trumpeter by Stephen Schaffner and the Pioneer Valley Symphony conducted by Nathan Gottschalk. In 1990, a memoir of her vaudeville experiences was published titled The Night the Camel Sang. She was 98 years of age at the time. ${ }^{6}$

\footnotetext{
${ }^{65}$ Susan Fleet, "Edna White Chandler," 9.

${ }^{66}$ Ibid., 10.

${ }^{67}$ Ralph Dudgeon, "An Interview with Edna White Chandler," 8.

${ }^{68}$ Susan Fleet, "Edna White Chandler," 10-11.

${ }^{69}$ Ibid., 10-11.
} 


\section{Katherine "Kitty" Rankin}

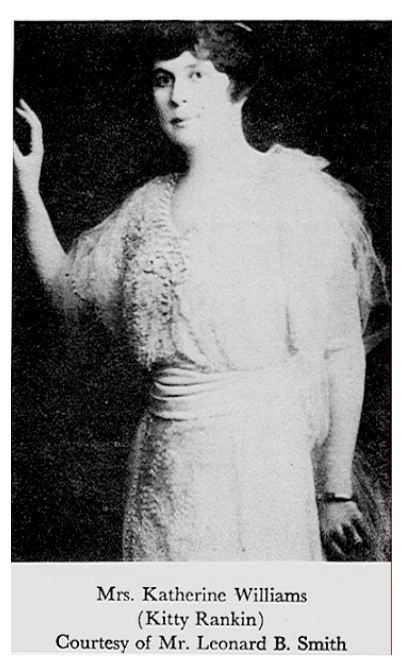

Figure 9. Katherine Rankin ${ }^{70}$

Katherine "Kitty" Rankin was the daughter of an alderman in Brockton, Massachusetts. She studied cornet with Mace Gay and performed in several local ensembles. In the August 1923 edition of Jacob's Band Monthly, Frank R. Selzer recalled hearing Rankin for the first time:

Many years ago the writer played at Nantasket Beach with Ellis Brooks and was amazed to see a little lass step out on the platform and play the "Russian Fantasia," considered at that time a very showy piece of work for cornetists. It often has been said of girl performers, "She plays well for a girl," but in her case such qualification was not necessary for she played excellently and could be compared with any of the noted soloists of the day. Her tone was of the finest, her technique was perfect, her phrasing left nothing to be desired, and we were safe in predicting at that time a grand future for her. She has fulfilled her early promise, is musicianly in every respect, and today stands without a peer. $^{71}$

In 1911, Rankin married her trumpet instructor, Ernest S. Williams, and they spent their first summer as a married couple in Colorado Springs, where Williams had accepted an engagement with Herman Bellstedt. Rankin and Williams performed together and as soloists with his ensemble at Lakeside Park in Denver, where they caught the attention of Hugh MacIntosh. Known as the Australian Impresario, MacIntosh booked the Williams for a one-year tour of Australia in 1913. This was followed by a tour of India, Egypt, Malta, Italy, France, and London, arranged for them by Maurice Bandmon, known as the Far-Eastern Impresario. They

\footnotetext{
${ }^{70}$ Pioneers in Brass, used with permission.

${ }^{71}$ Frank R. Seltzer, "Famous Bandmasters in Brief: No. 58 - Ernest S. Williams," Jacobs Band Monthly (August 1923): 16-7, in Keith Winking, “The Legacy of Ernest S. Williams," International Trumpet Guild Journal 24, no. 2 (January 2000): 38-9.
} 
were performing in the music halls of London when World War I began. Upon their return to America, they toured the vaudeville circuit until $1916 .^{72}$ One reviewer of their work observed:

Ernest Williams and Katherine Rankin did fair execution on the cornets. They made a very natty appearance and the act, in its way, is a novelty. This was their first America appearance since their return, recently, from Australia. ${ }^{73}$

Rankin performed as a soloist for the Park Band of Rochester, conducted by Theodore Dossenbach, for five summer seasons. Her solo repertoire included solos by John Hartmann, Jules Levy, Herbert L. Clarke, and others that were composed especially for her. ${ }^{74}$ One of the published concert programs listed her as performing "The Lost Chord" by Sir Arthur Sullivan. ${ }^{75}$

When Edna White left her quartet, the Edna White Trumpeters, Rankin took her place. When White reclaimed the name of the ensemble, Rankin retained the personnel, and the group then came to be known as the Gloria Trumpeters. ${ }^{76}$ This all-female trumpet quartet was highly successful, performing before large audiences in the city and the surrounding areas for at least twenty years. A 1930 newspaper article in the Binghamton Press stated that Ernest Williams trained the ensemble that was led by his wife. ${ }^{77}$ A January 23,1931 concert review in the same newspaper reported that the group was quite popular and had appeared in the largest cities, colleges, and universities. The article went on to state:

Their number is four, all women: Katherine Williams, Louise Gura, Cora Roberts and Mabel Chapman. Their place in the musical world is unique, dating from 1914, when the trumpet quartet was formed, with immediate success due not only to the novelty of the combination, but also to enlargement of scope of activities and recognition of the real musical worth of the group. The sounds of the trumpet adequately fill the largest auditorium, being also adaptable to outdoor gatherings and pageantry. By contrast, the tone in soft ensemble is appropriate for concert, church or drawing room. ${ }^{78}$

The ensemble performed ceremonial, sacred, and classical music depending on the venue. For a Lenten Concert given at the Plymouth Congregational Church in Utica, New York on February 19, 1921, the program listed the following pieces: "Marche Militaire" by Schubert, "Liebestraum" by Liszt, "Polonaise" by Beethoven, "The Robin Sings in the Apple Tree" by MacDowell, "Calm as the Night" by Bohm, "Garden Scene" from Faust by Gounod, "Daybreak"

\footnotetext{
${ }^{72}$ Seltzer, "Famous Bandmasters in Brief," 39.

${ }^{73}$ New York Clipper, 29 August 1914(?) (Old Fulton NY Post Cards).

${ }^{74}$ Seltzer, "Famous Bandmasters in Brief," 28.

75 "Special Concert by Park Band at Genesee Valley Park This Evening," Rochester Democrat and Chronicle, 16 Jul 1922 (Old Fulton NY Post Cards).

${ }^{76}$ White indicated in her interview with Ralph Dudgeon that Rankin replaced her in the Edna White Quartet, but that they never performed together in the same group. Initial reportage of the Gloria Trumpeters appears in the New York Times in 1919, at about the same time that White took back her ensemble name.

77 "Conway Band to Entertain for Shriners," Binghamton Press, 10 Apr 1930 (Old Fulton NY Post Cards).

78 "Gloria Trumpeters to Stage Special Concert Program at Boulevard Church Monday," Binghamton Press, 23 January 1931 (Old Fulton NY Post Cards).
} 
by Pueret and "La Reine de Baba" by Elgar. The program also indicated that the quartet was "well and favorably known throughout the United States.,"79 Another program performed in early May, 1923 at Christ Church in Poughkeepsie, New York was to include "The Lord is My Light" by Allison, and "Not Unto Us, O Lord" by Marks. The quartet performed a processional and assisted with the anthem, "Unford Ye Portals" by Gounod. A Poughkeepsie Eagle-News review described one of their church performances:

They performed with great beauty of tone, with abundant musicianship, and with a stirring vibrant quality that was profoundly affecting. They added brilliance and sonority to the hymns, and in their own special numbers combined with the organ with fine effect. In the "Seek Ye the Lord," one of the players had several measures alone, and showed the individual excellence of the group. Her tone was firm and vibrant, the phrases were molded with sureness and with the requisite musical feeling. In the ensemble sections the players were as one, and the genuine religious significance, poignance and beauty of the performance was clear to all who heard. ${ }^{80}$

The quartet performed for numerous church services, including large gatherings for Christmas and Easter Holidays. They led several parades and provided music for other special events conducted throughout New York City, including a performance at the dedication of a World War One memorial in Prospect Park on June 26, 1921 before a crowd of 35,000. ${ }^{81}$ The four women appeared at a Christmas concert at the Tree of Light in Madison Square Park on December 25, 1922, where they played for several thousand people who attended, and they followed with a repeat performance at the Metropolitan tower that was broadcast by radio. ${ }^{82}$ They led a procession of seven thousand at New York University for the unveiling of the busts in the Hall of Fame in May 1928, and performed a special program of incidental music, some of which was composed specifically for that occasion. ${ }^{83}$ In 1934, they performed for the holiday festivities at the Rockefeller Center Christmas tree dedication, providing both an indoor and an outdoor program. ${ }^{84}$ They were repeatedly asked to return to some of these events that occurred on an annual basis.

As with many of the all-women's groups of that time period, much attention was paid to the performers' dress. For their outdoor performances, one observer wrote that they "dressed in flowing silken robes, [and] were protected from the cold only by white woolen gloves." "85

Pictures reveal that one of their performance outfits was a Grecian-style white floor-length gown

\footnotetext{
79 “Gloria Trumpeters to Give Lenten Concert," Utica Morning Telegram, 17 Feb 1921 (Old Fulton NY Post Cards).

80 "Gloria Trumpeters Perform at Service in Christ Church," Poughkeepsie Eagle-News, 4 May 1925 (Old Fulton NY Post Cards).

81 "Brooklyn Unveils Honor Roll of Dead: Mayor Accepts for City Granite War Memorial in Prospect Park," New York Times, 27 Jun 1921 (Proquest).

82 “Throngs at Concert Under Tree of Light," New York Times, 26 December 1922 (Proquest).

83 "To Unveil 5 Busts at N.Y.U. on Thursday: Hall of Fame to Get Likenesses of Agassiz, Choate, Jones, Morese, and Whittier," New York Times, 6 May 1928 (Proquest).

84 "Rockefeller Center Gets A 70-Foot Tree," New York Times, 19 December 1934 (Proquest).

85 "Crowds Sing Carols at the Tree of Light: Passers-by in Madison Square Join Gloria Trumpeters in Christmas Music," New York Times, 26 December 1935 (Proquest).
} 
with white shoes and wide, decorative bands worn around their heads. The "Gloria Trumpetersthree women in white robes - sounded the arrival of Lindbergh's car..." at the end of the parade with thousands of people in attendance upon his return to New York City in $1927 .{ }^{86}$

The Gloria Trumpeters were featured on the Cadman Radio Hour, a religious show produced by the Federal Council of Churches of Christ in America. ${ }^{87}$ The group recorded "Come where the Lillies Bloom" and "How Sweet the Moonlight" for the Columbia Graphophone Company in 1920. ${ }^{88}$ Newspaper references to their performances stop towards the end of the 1930's. At some point Katherine and Ernest Williams separated and both remarried. Rankin was later referred to as Katherine Williams-Manley. ${ }^{89}$

\section{Grace Adams East}

Grace Adams East was another trumpet soloist who received performance work through the Redpath Bureau. According to her publicity material, she performed as a featured artist with the D. A. R. (Daughters of the American Revolution) Congress in Washington, D.C., the United States Navy Band, and with the New York Women's Symphony Orchestra. Other references printed in her publicity material include the following:

Out of the West came Grace Adams East, and showed this town that a woman can play the trumpet - instrument of soldiery and of Gabriel, the male angel - as well, and better, than most men. Slender and handsome, she played her concert on the trumpet last night, in admirable fashion, proved she was not only capable but an artist and sent her golden notes ringing against the beamed ceiling - Washington (D.C.) Daily News ${ }^{90}$

Grace Adams East is a solo trumpetist whose lovely tone is most pleasing to hear. It is very rare for a man, therefore most unusual for a woman, to master the technical difficulties of this instrument to such a degree of virtuosity. Her finesse of technique, her feeling for musical interpretation and her charm of personality combine to make it a pleasure to recommend Miss East as an artist of real quality. - Antonio Brico, New York Women's Symphony Orchestra ${ }^{91}$

A May 11, 1936 review in Time focused first on her appearance and then on the success of her performance:

At a "Concert In Time" in Washington, D.C. last week the solo performer was a darkhaired, comely young woman who appeared in a low-cut Nile-green gown, bowed

\footnotetext{
${ }^{86}$ Andrew Scott Berg, Lindbergh, (New York: The Berkeley Publishing Group, 1998), 156.

${ }^{87}$ Schwartz, "The Cornet Compendium."

${ }^{88}$ Iowa Digital Library, http://digital.lib.uiowa.edu (accessed February 10, 2009).

${ }^{89}$ Keith Robert Winking, "Ernest Williams, virtuoso and educator: A biographical survey of his philosophies and techniques," 17.

90 "Grace Adams East," Redpath Chautauqua Collection, University of Iowa Libraries Special Collections Department, http://sdrcdata.lib.uiowa.edu/libsdrc/details.jsp?id=/east/1 (accessed February 8, 2009).

${ }^{91}$ Ibid.
} 
graciously to her audience, raised a gold trumpet to her lips, closed her eyes and proceeded to tootle. Her arm muscles twitched while she played. The ruffles on her bosom and the orchids on her shoulder fluttered fitfully with each inspiration. But otherwise there were no signs of exertion.

Mrs. Grace Adams East of Berkeley, California is a sure mistress of the trumpet, which she first took up to develop breath control when she thought seriously of becoming a singer. She proved her feeling for tone last week with Schubert's "Du bist die Ruh" and the "Ave Maria," her facility at triple-tonguing with Rimsky-Korsakov's "Hymn to the Sun," her physical stamina when at the end of her program she played three encores. ${ }^{92}$

Ray Hastings, organist for the Philharmonic Orchestra in Los Angeles described East as "a genuine artist whose playing has been counted among the finest attractions ever enjoyed at the Philharmonic auditorium. In tone, quality, phrasing, and general style which Schubert songs demand, Mrs. East has no equal. ${ }^{, 93}$ An announcement in the Big Spring Daily Herald said the following in preparation for her upcoming performance on February 9, 1938:

Under the trumpeter's skillful handling, the instrument becomes a medium of interpretation in which color and expressiveness are the outstanding characteristics. Not only is the trumpet seldom used in recital but it is also rare to hear it played superbly by a woman. ${ }^{94}$

East was billed as America's Premiere Lady Cornetist for her appearance on a radio program she directed on March 26, 1926 in Salt Lake City. Table 7 lists the repertoire she performed for that radio appearance, and also for a Northbrae (California) Women's Club meeting in September 1930.

\footnotetext{
92 "Trumpeter," Time, 11 May 1936 (Time.com).

93 "Soloist is Praised by the Leading Musicians," Big Spring (Texas) Daily Herald, 9 February 1938, p. 4 (NewspaperARCHIVE.com).

94 "Soloist is Praised by the Leading Musicians."
} 
Table 7. Grace Adams East Partial Repertoire List

\begin{tabular}{l|l|l}
\hline Repertoire performed by East on Radio Program & \\
\hline Title of Piece & Composer & Instrumentation \\
\hline Where My Caravan Has Rested & Lohr & Trio with cellist and pianist \\
\hline One Sweet Day & Trio with cellist and pianist \\
\hline Dawn & Curran & Cornet solo \\
\hline Fantasie Brilliante & Arban & Cornet solo \\
\hline The Swan & Saint-Säens & Trio with cellist and pianist \\
\hline Indian Dawn & Zamenick & Trio with cellist and pianist \\
\hline Waters of Minnetonka & Cieurance & Cornet solo \\
\hline Land of the Sky Blue Water & Cadman & Cornet solo \\
\hline My Heart at Thy Sweet Voice & Saint-Säens & Cornet solo \\
\hline One Fleeting Hour & Lee & Trio with cellist and pianist \\
\hline A Perfect Day & Bond & Trio with cellist and pianist \\
\hline Repertoire performed by East at Northbrae Women's Club Meeting & \\
\hline La Cieca" from "La Gioconda & Ponchinelli & \\
\hline Madrigal & Chaminade & \\
\hline My Love is a Muleteer & Di Nogero & \\
\hline Hills of Home & Oscar Fox & \\
\hline Let All My Life Be Music & Gilbert Spross & \\
\hline The Rogue Song & unknown & \\
\hline & \multicolumn{2}{|}{} \\
\hline
\end{tabular}

Throughout her career, East appeared with symphony orchestras, gave numerous recitals, played nightclubs in the United States and abroad, and even performed for presidents Dwight D. Eisenhower and Franklin D. Roosevelt. ${ }^{97}$ She appeared in the summer of 1938 as guest soloist with the U.S. Navy Band in two "Patriotic Hour of Memories" broadcasts. ${ }^{98}$ In addition to her performance activities, she was active in supporting the musical arts, serving as president of the Etude Club of Berkeley, Vice President of the San Francisco Musical Club, and captain in the European Theater United Service Organizations (USO). She died on August 26, $1968 .^{99}$

\footnotetext{
95 “Broadcast Extraordinary! Over Radio Station KSL," The Salt Lake Tribune 26 March 1926 p. 11 (NewspaperARCHIVE.com).

96 "Northbrae Entertains with Tea," Oakland Tribune, 21 September 1930, p. S-5

(NewspaperARCHIVE.com).

97 "Rites Held for Lady Trumpeter," Oakland Tribune, 5 September 1968, p. 22E

(NewspaperARCHIVE.com).

${ }^{98}$ Soloist is Praised by Leading Musicians."

99 "Rites Held for Lady Trumpeter."
} 


\section{Chapter 4 - New Opportunities Resulting from World War II}

Believing they had proven themselves capable in the women's symphonies, some of the instrumentalists began to push for inclusion in the professional symphony orchestras. ${ }^{1}$ The outbreak of World War II and the resulting draft provided the opportunity for which they had been waiting. Needing replacements for the men fighting in the war, symphony orchestras became more open to hiring women. ${ }^{2}$ Many of those women hired had learned the symphonic literature in the all-women orchestras. Opera, radio, ballet, and theater orchestras hired women as well. In 1943, the Philadelphia Opera Company employed the largest number of women musicians in its history to replace men called to war duties. ${ }^{3}$

Beth Abelson Macleod examined orchestral membership lists from the 1940s to the 1980s, and saw a pattern indicating that the possibilities for women to achieve positions in orchestras were highly dependent upon the instruments that they played. While string players, keyboard players, harpists, and some woodwind instrumentalists achieved moderate to above average success, females who played percussion, string bass, or brass instruments other than the French Horn represented fewer than fifteen percent of the total membership of the orchestras in the study (see Table 8).

\begin{tabular}{|c|c|c|c|c|c|}
\hline Decade & 1940s & $1950 \mathrm{~s}$ & $1960 \mathrm{~s}$ & $1970 s$ & $1980 \mathrm{~s}$ \\
\hline Number of Orchestras & 47 & 63 & 36 & 49 & 44 \\
\hline Violin & 46 & 44 & 41 & 57 & 53 \\
\hline Viola & 33 & 29 & 34 & 36 & 45 \\
\hline Cello & 44 & 47 & 45 & 55 & 53 \\
\hline String Bass & 23 & 14 & 13 & 16 & 14 \\
\hline Flute/Piccolo & 44 & 43 & 44 & 54 & 61 \\
\hline Clarinet & 14 & 10 & 9 & 16 & 12 \\
\hline Oboe/English Horn & 3 & 21 & 19 & 30 & 41 \\
\hline Bassoon & 19 & 14 & 12 & 22 & 36 \\
\hline Trumpet & 8 & 5 & 2 & 5 & 5 \\
\hline Trombone & 6 & 5 & 4 & 2 & 3 \\
\hline French Horn & 18 & 14 & 12 & 16 & 27 \\
\hline Tuba & 7 & 2 & 0 & 0 & 2 \\
\hline Percussion & 13 & 9 & 14 & 12 & 6 \\
\hline Keyboard & 64 & 64 & 42 & 54 & 60 \\
\hline Harp & 80 & 89 & 82 & 88 & 90 \\
\hline
\end{tabular}

\footnotetext{
${ }^{1}$ Carol Neuls-Bates, Women in Music, p. 251.

${ }^{2}$ Block, p. xxiii.

3 "Opera and Concert: Philadelphia Company Hires Group of Women for Its Orchestra," New York Times 24 Oct 1943 (Proquest).

${ }^{4}$ Beth Abelson Macleod, “'Whence Comes the Lady Tympanist?' Gender and Instrumental Musicians in America, 1853-1990,” Journal of Social History 27, no. 2 (Winter 1993): 303 (http://www.jstor.org).
} 
In New York City, Leon Barzin, founder of the National Orchestral Association, reported an increase in the number of women in the orchestra, from $12-15 \%$ prior to the war, to $50-60 \%$ during the war. ${ }^{5}$ The purpose of this eighty-five piece training orchestra was to "without charging any tuition, train qualified young musicians to fit smoothly into professional jobs in major and minor philharmonic orchestras, ensembles, radio, and theatre orchestras."

With the better female instrumentalists being given positions in some symphony orchestras, the quality of and demand for women's orchestras began to decline. By 1950, only six women's orchestras were still active. ${ }^{7}$ While this shift was beneficial to those able to obtain positions, it was an opportunity lost for those women who performed on instruments still perceived as being unconventional.

An interesting comparison can be made between the orchestras that hired female hornists and those that hired female trumpeters (see Table 9). Margaret Grant conducted a study in the early 1940s that divided symphony orchestras into categories dependent upon their budgets. She then divided each category into three groups: major orchestras (groups one through three) had an operating budget of over $\$ 100,000$ for a regular season and secondary orchestras (groups four through six) were those with a budget smaller than $\$ 100,000 .^{8}$ Quite a few hornists were able to obtain positions in the Major category while their trumpet counterparts appeared to be not quite as successful.

\footnotetext{
${ }^{5}$ Jenkins, Women as Professional Horn Players in the United States, 13.

${ }^{6}$ Florence Haxton Bullock, "Women Musicians Make Good In the Big-Time Orchestras," New York Times, 13 Jul 1944 (Proquest).

${ }^{7}$ Jenkins, Women as Professional Horn Players, 13.

${ }^{8}$ Margaret Grant and Herman S. Hettinger, America's Symphony Orchestras and How They are Supported, (New York: Norton and Company, 1940) 13-14.
} 
Table 9. Orchestras hiring female horn and trumpet players. ${ }^{9}$

\begin{tabular}{|c|c|c|c|c|}
\hline Decade & Horn $^{10}$ & Group & Trumpet $^{11}$ & Group \\
\hline \multirow[t]{4}{*}{$1930 \mathrm{~s}$} & New Orleans Symphony & & Tri-City Orchestra & \\
\hline & Pittsburgh Symphony & 3 & & \\
\hline & San Antonio Symphony & & & \\
\hline & Seattle Symphony Orchestra & & & \\
\hline \multirow[t]{14}{*}{$1940 \mathrm{~s}$} & Atlanta Symphony Orchestra & & Altoona Symphony Orchestra & \\
\hline & Buffalo Philharmonic Orchestra & 4 & Billings Symphony Orchestra & \\
\hline & Chicago Symphony Orchestra & 2 & Brooklyn Symphony Orchestra & \\
\hline & Detroit Symphony Orchestra & 2 & Cedar Rapids Symphony & \\
\hline & Dallas Symphony Orchestra & & Duluth Symphony Orchestra & \\
\hline & Houston Symphony Orchestra & 4 & Enid Symphony Orchestra & \\
\hline & Indianapolis Symphony Orchestra & 3 & Flint Symphony Orchestra & \\
\hline & Kansas City Symphony Orchestra & 3 & Kearney Symphony Orchestra & \\
\hline & National Symphony Orchestra & 3 & Louisville Symphony Orchestra & \\
\hline & New Orleans Symphony & 4 & New London (CT?) Symphony & \\
\hline & San Antonio Symphony Orchestra & & Radio City Music Hall & \\
\hline & Seattle Symphony Orchestra & & $\begin{array}{l}\text { Southern Symphony Orchestra } \\
\text { (Columbia, SC) }\end{array}$ & \\
\hline & & & Terre Haute Symphony Orchestra & 6 \\
\hline & & & Tri-City Symphony & \\
\hline \multirow[t]{7}{*}{$1950 \mathrm{~s}$} & Atlanta Symphony Orchestra & & Billings Symphony Orchestra & \\
\hline & Buffalo Philharmonic Orchestra & 4 & $\begin{array}{l}\text { Southern Symphony Orchestra } \\
\text { (Columbia, SC) }\end{array}$ & \\
\hline & Chicago Lyric Opera & & Tulsa Symphony Orchestra & \\
\hline & Detroit Symphony Orchestra & 2 & Metropolitan Opera (extra) & \\
\hline & Kansas City Symphony Orchestra & 3 & & \\
\hline & National Symphony Orchestra & 3 & & \\
\hline & Pittsburgh Symphony Orchestra & 3 & & \\
\hline
\end{tabular}

\footnotetext{
${ }^{9}$ No entry in the group column indicates that the orchestra was not listed in the study.

${ }^{10}$ Information obtained from Jenkins, Women as Professional Horn Players appendices.

${ }^{11}$ Information collected from "Women Brass Musicians: Past and Present," Eloise Jenkins' collection of orchestral rosters, and Norman Schweikert letter to author, 10 January 2009.
} 


\section{Leona May Smith}

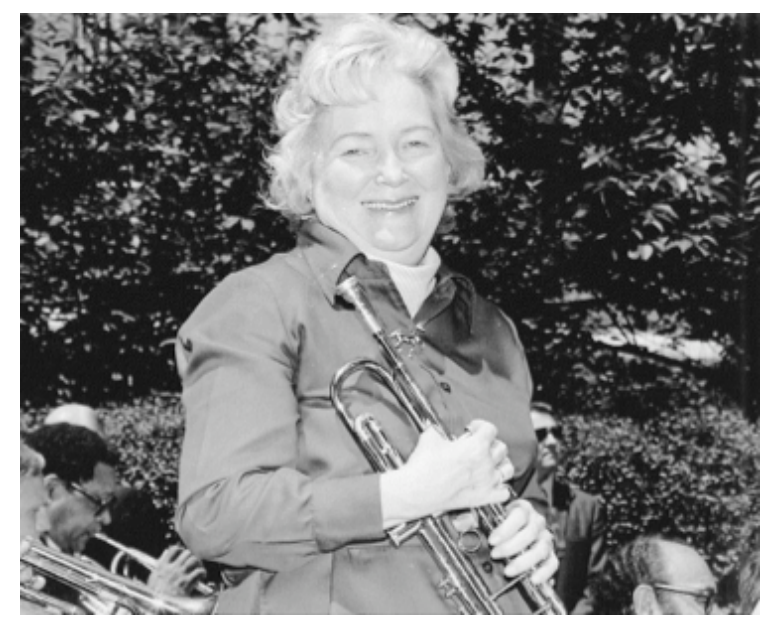

Figure 10. Leona May Smith

One female trumpeter to train with the National Orchestral Association and achieve considerable success as a performer was Leona May Smith, "an attractive, vital-looking young woman." Smith was principal trumpet with the orchestra and had won the Ossip Gabrilowitsch Scholarship Fund Award for the season 1942-43. ${ }^{12}$ This prize was awarded annually to the member of the orchestra who was "judged to be most worthy of the honor on the basis of loyalty, musicianship, cooperation, and personal qualities."13

Born in Bridgeport Connecticut in 1914 to Willard and Carrie Smith, Leona began her study of cornet at eight years of age with her father, a trombone and bass player. The young Smith was highly motivated to master the instrument. "It had nothing to do with gender, I wanted to play the trumpet because that was my gut feeling ... all I cared about." "She began studying with Walter M. Smith, leader of the Oliver Ames Band in North Easton, at age ten. At age eleven she was performing as a trumpet soloist in various church services and entertainments in the Boston area. Soon after, on September 18, 1926, she performed the cornet solo "Willow Echoes" by Frank Simon with the Ames Band. She was appointed the official trumpeter of the Edison Electric Illuminating Company Big Brother Club and performed regularly on its radio broadcasts. $^{15}$

When she was fourteen, Walter M. Smith and another of her teachers, Georges Mager (then principal trumpet with the Boston Symphony), both recommended Smith for the principal trumpet chair in the Boston Women's Symphony. She performed with them for two seasons

\footnotetext{
${ }^{12}$ Bullock, "Women Musicians Make Good."

13 "Leona Smith Wins Award," New York Times, 23 May 1943 (Proquest).

${ }^{14}$ George Hanlon, "Polished Brass: Plymouth Musician Honored as Pioneer," The Sunday Enterprise, 13 June 1993.

${ }^{15}$ From the author's collection of Smith's papers.
} 
under the baton of Ethel Leginska. This was her first experience with a symphony orchestra, and it allowed her to further develop her reading and technical skills. ${ }^{16}$

At the age of seventeen, Smith moved to New York City where she continued to develop her orchestral abilities. She performed as a soloist and in the sections of the Fred Waring Orchestra and the Chautauqua Symphony Orchestra (summer season 1943). The first female trumpeter to perform as a stage soloist at Radio City Music Hall, Smith also played first trumpet in the Music Hall Orchestra, performing with them from 1943 to 1945. She performed at many theatres, including the Roxy Theatre in New York City, and with orchestras throughout the northeastern seaboard. She appeared as a soloist with the Goldman Band for a concert in Central Park, performing Del Staigers' arrangement of Herbert L. Clarke's "Carnival of Venice". ${ }^{17}$ In 1941, she gave the second performance of Aaron Copland's Quiet City. She was first trumpet in the Brooklyn Symphony conducted by Sir Thomas Beecham, and was the first woman brass player hired by the Metropolitan Opera Orchestra, serving as an "extra" for twenty years (19531973). ${ }^{18}$

Smith married bandmaster George Seuffert when she was nineteen, and raised four sons while maintaining an active performance career. Both she and Seuffert were quite well known in the field of music education and in the band world. In 1931, Seuffert assumed leadership of the Seuffert Band, an ensemble that was created by his father. Smith oversaw the business aspects of the ensemble including selecting the musicians, business management, contractual responsibilities with the local musicians union, and "showcase" areas of the operation. She was also principal trumpet, assistant conductor, and a soloist. The ensemble was partially funded by the city of New York and performed free concerts on a regular basis. ${ }^{19}$

The Seufferts founded the Music for Youth program in 1947, a summer camp for young musicians, which provided musical opportunities such as band, orchestra, private instruction, ensemble training, and solo activities. Bandmaster Edwin Franko Goldman served as chairman of the advisory committee and was an avid supporter of the program. ${ }^{20}$ Goldman was a guest conductor on the final concert of the 1953 summer event, and the following was reported in the local newspaper:

He [Goldman] then told the story of his first meeting with Leona May Smith, now Mrs. Seuffert, when as guest of the late Edward Filene [founder of the department store Filene's] in Boston she phoned him saying, "Welcome to Boston," and promptly played a selection on her cornet. Asking for an audition, he gave her one. "She was eight [ten] years of age and is now one of the greatest cornetists we have," Dr. Goldman noted. ${ }^{21}$

\footnotetext{
${ }^{16}$ Hanlon, "Polished Brass."

${ }^{17}$ From the author's collection of Smith's papers.

18 "Biographies of the 1993 Honored Pioneers," Newsletter of the International Women's Brass

Conference 1, no. 3 (August 1993): 4.

${ }^{19}$ From the author's collection of Smith's papers.

${ }^{20}$ Carol McClure, "Fame of Seufferts Now International," Ridgewood Times, 25 June 1953 (Old Fulton NY Post Cards).

${ }^{21}$ Gertrude Albee, "Music Center Students Present Final Concert," The Newport Daily Express, 22 August 1953 (Old Fulton NY Post Cards).
} 
Her telephone audition resulted in a performance at Filene's where Goldman was appearing as a guest artist for the weekend. ${ }^{22}$ In January 1938, Smith published a column in Metronome with her answer to a question frequently asked of her, "Is There a Career for Women Musicians?"

My answer always is, "Yes! Decidedly!" There has been a tremendous growth in girl dance orchestras and women's symphony ensembles in recent years. However, with few exceptions, they are not as financially remunerative as those of men or as they will eventually be. The development of girl and women musicians has been retarded mainly because of the attitude accorded women in this field. ${ }^{23}$

She went on to promote teaching as one of the steadiest forms of income for "girl" musicians saying that "This is a field in which they can equal the best of men instructors, and in many cases, they surpass the mediocre instruction given by so many male musicians who view teaching solely as a means of augmenting their regular income. ${ }^{, 24}$ Teaching was a big part of Smith's life: she had taught privately as well as coached students in both public and private school band programs.

A 1969 article in the Long Island Press noted Smith's performances at the pre-race concerts at Belmont Park and Aqueduct, suggesting she was a favorite of racing fans, and had been known to "bring the house down" with her performances of "Carnival of Venice." Smith shared the following: "Hitting a high batting average is the most you can do as a performer. If it's cold your muscles are stiff, and if it's hot, they're too soft. On a humid day at the track, the sound is dulled, but when the day is clear, and the track "fast" we're off and running." 25

Smith moved to Plymouth, Massachusetts in 1973 and managed the Ryder Home for elderly women for at least fourteen years. She continued to play her trumpet and wrote a trumpet method book. ${ }^{26}$ In 1993, she was one of the first recipients of the International Women's Brass Conference Pioneer Award, given to women who were truly distinguished brass musicians. She passed away on December 1, 1999. Her son, Peter Seuffert wrote in tribute,

She was very proud of being a "trailblazer" for other women who were pursuing a career in music. She was the first woman to play at the Metropolitan Opera in New York and was well known as a virtuoso in the US and Canada. She played until two weeks ago - a career that spanned seventy-one years. Remember the Trailblazers. ${ }^{27}$

\footnotetext{
${ }^{22}$ Hanlon, "Polished Brass."

${ }^{23}$ Leona May Smith, "Is There a Career for Women Musicians?” Metronome 54, no. 1 (January 1938): 49.

${ }^{24}$ Ibid.

${ }^{25}$ Sylvia Federman, “Lady Trumpeter Posts Many Firsts,” Long Island Press, 9 October 1969, p. 28.

${ }^{26}$ Hanlon, "Polished Brass."

27 “Leona May Smith, 1914-1999," International Women's Brass Conference Newsletter 4, no. 9 (Winter 1999): 1 .
} 


\section{The All-Women Military Bands}

On May 15, 1942, Franklin Delano Roosevelt signed a bill into law, creating the Women's Army Auxiliary Corps. The concept was to place women in certain positions normally held by men in order to free those men for field duty. The other branches of the service soon followed suit and eight women's military bands were formed in support of these women's forces. They performed for the same functions as their male counterparts, including concerts, graduations, dances, parades, and at hospitals. They toured the United States promoting the sale of war bonds, raising millions of dollars to help sustain the war effort. Women who served as instrumentalists in these ensembles came from varied backgrounds: some having trained formally and others having learned in their school, family, college, or swing bands, as well as in women's orchestras. ${ }^{28}$

The Army formed five women's bands, the $400^{\text {th }}, 401^{\text {st }}, 402^{\text {nd }}, 403^{\text {rd }}$, and $404^{\text {th. }}$. The $400^{\text {th }}$ Women's Army Corps (WAC) band, based at Fort Des Moines, was active the longest, existing until 1976. ${ }^{29}$ Instrumentation was set at twenty-eight pieces per band, including seven trumpet players (see Table 10). One trumpeter with the band, Louise Byrd, enlisted as a trumpeter, and arrived on base prior to the activation of her unit. She rehearsed and trained with the male post band for approximately three months until the women's band was ready to begin its duties. The men's band was eventually transferred to Fort Harrison, Indiana, and the women's band took over its performance responsibilities. Byrd recalled that she was the first female chosen to replace the bugler. Her post for this duty was to stand beside a cannon that was fired immediately prior to her performance. When she was to sound the retreat for the first time, she was surprised by the loud noise, and had to collect herself before beginning to play. ${ }^{30}$

A typical week of performances included playing the troops to and from class three times per day, formal parades and concerts given twice weekly, and dance band performances on weekends. The band appeared with entertainers such as Bob Hope, Bing Crosby, Captain Ronald Reagan, Errol Flynn, and Dale Evans. The band's repertoire included marches, standard band pieces, and orchestral transcriptions along with pieces that featured individual personnel in the band. $^{31}$

Throughout its thirty-four year tenure, the band performed for regimental parades, march outs, retreats, battalion reviews, basic training graduations, officer training orientations and graduations, opening and closing ceremonies, post functions, charity events, and community concerts. The military uniform worn by the band included specially authorized white scarves and

\footnotetext{
${ }^{28}$ Jill M. Sullivan, “A Century of Women's Bands in America,” Music Educator's Journal 95, no. 1 (Sep 2008): 35 .

${ }^{29}$ Jill M. Sullivan, “Women's Army Corps Bands,” Arizona State University, http://www.public.asu.edu/ jmsulli/Webpages/wac.html (accessed February 22, 2009).

${ }^{30}$ Jill M. Sullivan, "Women's Military Bands in a Segregated Army: The $400^{\text {th }}$ and $404^{\text {th }}$ WAC Bands," Journal of Band Research 41, no. 2 (2006): 7-8.

${ }^{31}$ Sullivan, "Women's Army Corps Bands."
} 
shoulder braids. The band performed Dixieland, German, folk, rock, dance, swing, and choral music depending on the type of event. ${ }^{32}$

\begin{tabular}{l|l} 
Table 10. Women's Army Corps Bands Trumpet Roster $^{33}$ \\
\hline Allenger, Eloise & \\
\hline Baldenecker, Donna Mae & \\
\hline Byrd, Louise & \\
\hline Foster, Margaret & \\
\hline Ginther, Lois & \\
\hline Hurling, Constance & First Trumpet, 404 \\
\hline Knouff Edith & \\
\hline Lamb, Joan & \\
\hline Miller, Sena & Second Trumpet, $404^{\text {th }}$ \\
\hline Moore, Violet & First Trumpet, $404^{\text {th }}$ \\
\hline Payne, Yvonne & \\
\hline Rigsbee, Virginia & Trumpet, $404^{\text {th }}$ (also played horn) \\
\hline Skinner, Clementine & Third Trumpet, 404 \\
\hline Sims, Ann & \\
\hline
\end{tabular}

The $400^{\text {th }}$ WAC band was quite popular and attracted the attention of the AfricanAmerican musicians on base who were interested in joining the group. Though the Army had indicated that there would be no discrimination in the duties of all of the women, black or white, all army military personnel were segregated, including the bands. Many qualified black women auditioned, but none was accepted into the $400^{\text {th }}$ band. In September 1943, the army created the $404^{\text {th }}$ Negro WAC band, so that the black troops could have their own band. Because many of the women were unable to read music at first but could play by ear, the $400^{\text {th }}$ band members were called upon to provide training in reading music and marching. Eventually growing to thirtymembers, the $404^{\text {th }}$ was given similar duties to the $400^{\text {th }}$ WAC band. Clementine Skinner, who played trumpet and horn with the group, recalled performing for mostly white audiences on the various bond drive tours, and that the band was often treated with celebrity status. Unlike the $400^{\text {th }}$, the $404^{\text {th }}$ WAC band was deactivated at the end of the war. ${ }^{34}$

The Marine Corps Women's Reserve (MCWR) Band was the last women's military band to be formed during the war and was organized by the top Marine personnel in Washington, D.C. The ensemble instrumentation was standardized at forty-three musicians, including four cornets and two trumpets (see Table 11). Women were recruited from across the country and it was

\footnotetext{
32 Therese Kerbey, "14 ${ }^{\text {th }}$ Army Band WAC, 1942-1976," Arizona State University, http://www.public.asu.edu/ tmontgom/ (accessed February 21, 2009).

${ }^{33}$ Jill Sullivan, Personal Collection, used with permission. This is a partial roster of information that has been compiled by Dr. Sullivan to date. Names listed are maiden names.

${ }^{34}$ Jill M. Sullivan, “ A History of the Marine Corps Women's Reserve Band," Journal of Band Research 42, no. 1 (Spring 2001): 12.
} 
suggested that they "present a nice appearance," "have a reasonable uniformity of height," and must be "most outstanding, as to character and ability."

Table 11. Marine Corp Women's Reserve Band Trumpet Roster ${ }^{36}$

\begin{tabular}{l|l}
\hline Adams, Margaret & Hammond, Helen \\
\hline Berlau, Dorothy & Harper, Anita \\
\hline Blue, Betty & Kerbaugh, Ann \\
\hline Clawson, Virginia & Marshall, Barbara \\
\hline Gerard, Ruth & Nobles, Nancy \\
\hline Goodell, Margaret & Ommert, Ruby \\
\hline Gustavsen, Ella & Woedtke, Dorothy \\
\hline
\end{tabular}

Having passed through boot camp and their Marine Corps musical training, the MCWR Band gave their first formal concert performance on January 28, 1944 at their home base of Camp Lejeune, North Carolina. The pieces on the program were as follows: "The Marines Hymn," The Star Spangled Banner," Louis Savernino's "March of the Women Marines," R. B. Hall's "Independentia" march, Grofe's "Mardi Gras" from Mississippi Suite, Herbert's "Kiss in the Dark" from Orange Blossoms, Isaac and Lillya's rhapsody "Deep South," Huffine's "Them Basses," Carmichael's "Star Dust," Borel-Clerc's "La Sorella," and Porter's "Begin the Beguine." 37

Similar to the men's bands, the women formed smaller groups from within the band including a big band and a Dixieland sextet. The ensembles performed for weekly concerts, graduation parades and guard mounts, regimental reviews, dances, hospital performances, and many civilian performances. Their first tour, in November 1944, included a stop in Chicago as well as at Marine Corps bases on the East Coast. The purpose of the tour was to raise money for the war effort and to boost the morale of the troops. In thirty-four days they performed fourteen concerts, twelve parades, eight color formations, five radio shows, five reviews, and one guard mount. One of the radio shows was a national broadcast, replacing the "President's Own" Marine Band for that performance. Another tour the following year lasted twenty-two days, with performances in twenty-two cities and included twenty-seven concerts, fifteen parades, three radio broadcasts, and one dance. ${ }^{38}$

The United States Air Force was formed in 1947, and women were recruited immediately to fill low skill and clerical jobs. The Women's Air Force (WAF) Band was organized as a tool to recruit women into the service and to provide music for ceremonies and troop entertainment. During their ten years of existence, they made eighty-eight tours for a total of 1,045 days, traveling to thirty-four states and sixty-nine military bases. Highlight performances include those

\footnotetext{
${ }^{35}$ Sullivan, " A History of the Marine Corps Women's Reserve Band," 7.

${ }^{36}$ Jill Sullivan Personal Collection, used with permission. This is a definitive list.

${ }^{37}$ Sullivan, “A History of the Marine Corps Women's Reserve Band," 14.

${ }^{38}$ Ibid., 15-17.
} 
given at Carnegie Hall, Rockefeller Center, and at the Hollywood Bowl. ${ }^{39}$ Backhaus lists thirtyone different female trumpet players who performed with the ensemble (see Table 12).

Table 12. Women's Air Force Band Trumpet Roster During the $1950 \mathbf{s}^{40}$

\begin{tabular}{l|l}
\hline Anderson, Valerie D & Mohr, Mary B \\
\hline Awkerman, Martha J. "Martye," & Morgan, Donna R. \\
\hline Barclay Ray, Bonnie M. & Powell, Mary A. \\
\hline Brink, Dorothy Ann & Pranger, Vivian L. \\
\hline Brown, Donna J. & Roger, Marilyn M. \\
\hline Byrd, Mary A. & Shalin, Donna M. \\
\hline Daugherty, Phyllis A. & Siegel, Nancy T. \\
\hline Emerson, Betty E. & Soucie, Shirlie \\
\hline Jackson, Cora J. & Strobele, Cynthia R. \\
\hline Jamison, Mary & Strobele, Shirley R. \\
\hline Johnson, Valerie J. & Tapley, Florence \\
\hline Jones, Margaret A & Tucker, Barbara A. \\
\hline Jordan, Rita & Watson, Mary J. \\
\hline Kasza, Judith E. & Wern, Shirley A. \\
\hline Langfang, Martha Joyce & Whaley, Carolyn L. \\
\hline Mathews, Helen L & \\
\hline
\end{tabular}

While not all of the women's military bands were considered to be elite ensembles, these organizations provided professional performance opportunities for female trumpet players and, for some, laid the foundation for continued work. The trumpeters were called upon to perform in a variety of ensembles and genres as well as to adhere to an active performance schedule.

Martha J. "Martye" Awkerman was a trumpet player and cornet soloist with the Women's Air Force Band from 1955 until 1961. Born in 1928, she received a degree in trumpet performance from the Cincinnati Conservatory of Music in the early 1950s. Her instructors were Frank Simon and Harold Mitchell. While with the WAF she traveled the world on USO tours and performed for civilian and military audiences. ${ }^{41}$ When the band was deactivated, she made an interesting response to a question on her exit paperwork inquiring about her plans for the future. While other band members indicated a wish to become flight hostesses, get married, or have families, Awkerman's desire was to play in the United States Air Force Band in Washington, D.C; however, she was unable to audition at that time, because the premiere Air

\footnotetext{
${ }^{39}$ Jeananne Nichols, "The United States Air Force Women's Band (WAF), 1951-1961," Arizona State University, http://www.public.asu.edu/ jmsulli/WAF_NICHOLS.htm (accessed February 22, 2009).

${ }^{40}$ Backhaus, "Source Guide for Research on Women Instrumentalists."

41 "Martha Awkerman WAF and Long Beach Band Papers, 1940-2002," University of Illinois Archives, http://www.library.uiuc.edu/archives/archon/index.php?p=collections/controlcard\&id=3133 (accessed March 5, 2009).
} 
Force Band was open only to men. ${ }^{42}$ In an interview with Sherrie Tucker, author of Swing Shift: All-Girl Bands of the 1940s, Awkerman shared the following anecdote: "This guy wanted to marry me. He said, 'It's me or the horn.' I said, 'Well, it ain't you babe.",43

Awkerman performed with a few different all-girl bands including the Hormel Girls and Maiden Voyage. ${ }^{44}$ In 1961, she became the first woman to play in the Long Beach Municipal Band, alongside many former members of the John Philip Sousa Band, and she continued to perform in the ensemble and as a cornet soloist until she retired in 1983. Awkerman earned the WAF Band Silver Trumpet Award and the Sigma Alpha Iota music sorority Life Time Achievement Award. ${ }^{45}$ She passed away in June, 2008 at the age of seventy-nine.

Having experienced some success during the war years, the situation changed for female musicians following the end of the war. Women who had been called upon to perform their patriotic duty by filling positions left open by men called to serve in the armed forces were expected to stand down in order for the returning GIs to reclaim their livelihoods. Although many women agreed that stepping aside was the right thing to do, surveys indicated that of the three million women who left the general workforce in 1946,70\% wanted to keep their jobs. ${ }^{46}$ One leader of a symphonic placement bureau recognized the fact that most conductors would ask for a male player, even if his playing proved to be inferior to that of his female counterpart. ${ }^{47}$ The percentage of women participating in the National Orchestral Association dropped from 50-60\% to approximately $25 \%$ after the war. ${ }^{48}$

Trumpet player Jane Sager performed in the Victory Belles, an all-woman radio band created for Columbia Broadcast System in Los Angeles during the war. ${ }^{49}$ When the war was over, she was told by the head of the music department that he had to let her go so he could hire returning servicemen who needed to have the work in order to support their families. Sager also had a family to support, but that was not a consideration for her employers. Like many other women who experienced the same situation, she looked to other occupations within her discipline for job opportunities. She worked as a music therapist with hospitalized soldiers, performed with some all-girl swing bands, and taught privately. For a time she organized a group called the Frivolous Five, a female musical comedy act with instrumentation of clarinet, trumpet, trombone, accordion, and drum set. The Hollywood Reporter referred to them as the Dixieland Dowagers, and their popularity stemmed from the group playing badly on purpose. ${ }^{50}$

\footnotetext{
${ }^{42}$ Chief Master Sgt. Jan Z. Duga, "Faithful to a Proud Heritage," Air Force Print News Today, August 29, 2008, http://www.bolling.af.mil/news/story_print.asp?id=123112418 (accessed February 19, 2009).

${ }^{43}$ Sherrie Tucker, Swing Shift: All-Girl Bands of the 1940s,(Durham and London: Duke University Press, 2000), 317.

${ }^{44}$ Ibid., $322 / 327$.

45 "Martha Awkerman WAF and Long Beach Band Papers."

${ }^{46}$ Jenkins, Women as Professional Horn Players, 14.

${ }^{47}$ Clara Burling Roesch, "The Plight of the Woman Symphonic Player," Music Clubs Magazine 31 no. 4 (March 1952): 36.

${ }^{48}$ Mary L. Stolfus, "Eve in the Ensemble" Musical Courier 136, no. 8 (December 1947): 17.

${ }^{49}$ Tucker, Swing Shift, 280.

${ }^{50}$ Ibid., 320 .
} 


\section{Chapter 5 - Women in Major Orchestras}

During the 1960's, female trumpeters began making inroads into the major orchestras in the United States. Marie Speziale won the associate trumpet position with the Cincinnati Orchestra in 1964, becoming the first woman trumpeter with a permanent position in a major orchestra. In 1966, Gail Hutchins began performing as the fourth trumpet with the Baltimore Symphony Orchestra. In 1968, Joyce Johnson-Hamilton was the first woman trumpeter to win a "blind" audition in a major orchestra, when she won the assistant principal position with the San Francisco Symphony. In 1969, Susan Slaughter won the fourth chair position in the St. Louis Symphony after serving two seasons as principal trumpet of the Toledo Symphony. During the 1972-73 season, Slaughter became the first woman to be a principal trumpeter in a major orchestra when she auditioned for and won the principal chair in St. Louis.

Speziale and Slaughter had a foot in the door, so to speak, prior to obtaining their positions. Speziale had performed with Cincinnati as a substitute for more than two years prior to auditioning for the associate job. Slaughter had performed as fourth chair and was called upon by the orchestra to substitute for the principal player when he unexpectedly resigned prior to the beginning of the season. Although Slaughter participated in the audition process, she had to continue to prove herself before being hired permanently. She shared the principal chair with another gentleman for four months, both playing halves of concerts, until she finally was awarded the permanent position in December, 1972. ${ }^{1}$

The success of these women reflected the overall trend being experienced by female orchestral musicians in general. In 1962, the International Conference of Symphony Orchestra Musicians (ICSOM) was founded in order to address certain issues raised by their members. These included a balanced workload, better pay, and a voice in the hiring and firing of musicians in the orchestra. ${ }^{2}$ In most of the orchestras, instrumentalists were hand-chosen by the music director. If there was an opening, phone calls would be made to instructors at universities and to orchestral players requesting recommendations. Personnel decisions were made at the sole discretion of the music director. One example of this was Joyce Johnson-Hamilton being hired by Maestro Jacques Singer to perform as principal trumpet with the Portland Symphony. Upon the recommendation of her section leader in the Aspen orchestra, Singer listened to her perform music of her choice, "Dance of the Ballerina" from Petroushka. Her audition location was behind the rehearsal tent at the Aspen Music Festival. She played it so well that he hired her on the spot. ${ }^{3}$

ICSOM demanded all open positions in union orchestras be advertised in union publications. This push resulted in an increased amount of potential candidates wanting to audition. In June 1963, ICSOM advocated the inclusion in all symphony contracts of a nondiscrimination clause. ${ }^{4}$ Eventually, audition committees included members of the orchestra in addition to the conductor and the section principal. The next step was to change the format of

\footnotetext{
${ }^{1}$ Susan Slaughter, interview with author, 24 February 2009.

${ }^{2}$ Jenkins, Women as Professional Horn Players, 39-40.

${ }^{3}$ Joyce Johnson-Hamilton, interview with author, 29 January 2009.

${ }^{4}$ Jenkins, Women as Professional Horn Players, 39-40.
} 
auditions to be "blind" or "screened" where the identity of the musician was unknown to the audition panel. ${ }^{5}$ By the 1970s, most major orchestras in the United States began to change their hiring practices. Studies have proven that the use of a screen increased the probability by fifty percent that a woman would advance from certain preliminary rounds, and also increased her chances in being selected into the final round of auditions. ${ }^{6}$

Examples of situations where a blind audition might have resulted in equal consideration for one female trumpeter can be seen in two audition experiences of Susan Slaughter, currently the principal trumpeter of the St. Louis Symphony Orchestra. Her audition with the Indianapolis Symphony resulted in a tie between her and a male candidate. The position was awarded to the man "because they felt that a woman wouldn't have the stamina to play the trumpet." The second experience occurred during her audition for the New York Philharmonic when she competed in the final round with Phil Smith and Louis Ranger for the principal trumpet position.

What I was told years later was that when I came out on stage to play the final round, Zubin Mehta was in the audience and said, "What's a woman doing up there? We're not going to have a woman in the brass section." So, that's what I found out years later. ${ }^{8}$

The question of whether or not Slaughter could have fairly won those positions had her sex been unknown will never be answered. To be certain, she was disqualified prior to playing a single note in the final round in New York by a conductor, who shared the following views regarding women in the orchestra with the New York Times (18 October 1970):

They are very good - they got their jobs in competition with men. I just don't think women should be in an orchestra. They become men. Men treat them as equals; they even change their pants in front of them. I think it's terrible!

Mehta was not alone in his beliefs: quite a few conductors agreed with him. Joyce Johnson-Hamilton had an experience similar to Slaughter's when she auditioned for a major orchestra and was informed by three different "rumor" sources that she had won the audition.

Several weeks later, confirmation came from the orchestra that I did not win. However, nine years later when I was in Wisconsin performing at the ITG [International Trumpet Guild] conference, a man introduced himself and said he was the out-going principal trumpet who ran the audition, and that I had actually won the audition, but the conductor had refused to hire me saying that the orchestra already had too many women. ${ }^{10}$

\footnotetext{
${ }^{5}$ Claudia Goldin and Cecilia Rouse, "Orchestrating Impartiality: The Impact of 'Blind' Auditions on Female Musicians," The American Economic Review 90, no 4 (September 2000): 716.

${ }^{6}$ Ibid.

${ }^{7}$ Susan Slaughter, interview with author, 24 February 2009.

${ }^{8}$ Ibid.

${ }^{9}$ Judy Klemesrud, “Mehta's Mystique: Baton in Hand, Foot in Mouth?” New York Times, 18 October 1970, 15/33 (Proquest).

${ }^{10}$ Joyce Johnson-Hamilton, interview with author, 29 January 2009.
} 
Marie Speziale, former associate principal trumpet with the Cincinnati Symphony Orchestra inquired about auditioning for the St. Louis Symphony in the 1960s when there was a trumpet opening. This performer, who held the principal chair in the Cincinnati Conservatory Orchestra for four years and had substituted with the Cincinnati Symphony for two years, was told not to come because the maestro refused to listen to women. ${ }^{11}$ The situation for African American women was even more difficult. In 1990, the American Symphony Orchestra League published the study The Participation of Blacks in Professional Orchestras that identified one hundred and twenty-three black musicians as members of professional orchestras. Thirty-one of those symphony performers were women; none was a trumpet player. $^{12}$

The Title IX Education Amendments of 1972 provided support for women seeking equal opportunity in that it stated that "No Person in the United States shall, on the basis of sex, be excluded from participation in, be denied the benefits of, or be subjected to discrimination under any education program or activity receiving Federal financial assistance."13 This law benefited those women trying to enter colleges and universities that had previously denied women entry. It also led to more women being hired as faculty at institutions of higher learning, and narrowed the gap in wages between men and women. Title IX put in place rules against sexual harassment in educational institutions, and made it illegal for anyone to commit any unwanted or unwelcome sexual behavior that significantly interfered with a student's access to educational opportunities. Increased access to higher education has allowed women to earn degrees at a higher rate than prior to Title IX, and has increased their earning ability. ${ }^{14}$

Speziale, Slaughter, Hutchins, and Johnson-Hamilton were success stories in that they were able to obtain professional positions as orchestral musicians. When orchestral opportunities were denied some women during the 1960s, like their predecessors, they looked elsewhere for performance opportunities. Carole Dawn Reinhart knew that if she wanted to stay in the New York City area, she would not be doing so as a member of one of the major orchestras there. She realized this when, as principal trumpet of the Julliard Orchestra, she was not invited to audition for a Metropolitan Opera Orchestra opening, even though the second and third chairs in her ensemble were invited. She chose to capitalize on the novelty aspect of her situation as a female trumpeter and was able to maintain a solo performance career for fifty years, although much of that career was spent outside of the United States.

\footnotetext{
${ }^{11}$ Marie Speziale, interview with author, 23 Dec 2008.

${ }^{12}$ Handy, "Black Women and American Symphony Orchestras," 24.

13 "Title IX, Education Amendments of 1972," United States Department of Labor, http://www.dol.gov/oasam/regs/statutes/titleIX.htm (accessed 16 April 2009).

14 “Ten Key Areas of Title IX," Title IX, http://www.titleix.info/10-Key-Areas-of-Title-IX/Access-toHigher-Education.aspx (accessed 16 April 2009).
} 


\section{Carole Dawn Reinhart}

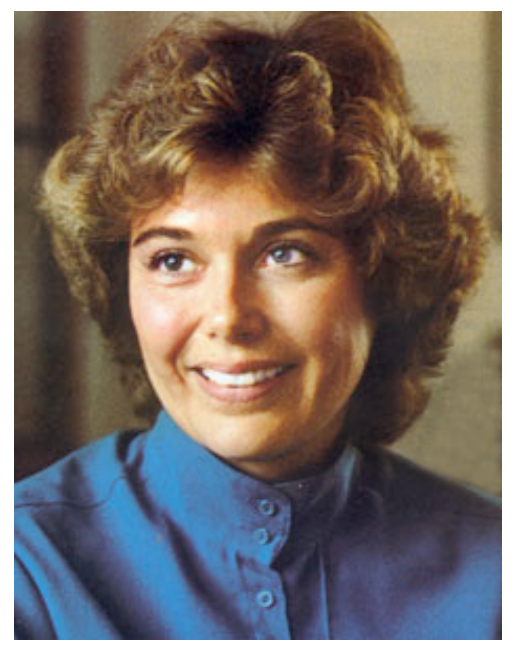

Figure 11. Carole Dawn Reinhart ${ }^{15}$

Born December 20, 1941 in Roselle New Jersey, Carole Dawn Reinhart began playing the slide cornet when she was just over two years old. Her mother Mabel Reinhart played the trombone and piano, and provided Reinhart with her first lessons. Her father sang in local church choirs and her brother, Rolfe, also played the cornet. When she was ten, she was awarded a scholarship to study with Edward Treutel at the Julliard School of Music in New York, having performed Edwin Franko Goldman's "Tramp, Tramp, Tramp" for her audition. Her father was constantly looking for opportunities for his children to perform, and encouraged them to play with the Salvation Army Band. When she turned sixteen, Reinhart was given her commission as a Bandmaster, the youngest and the first female to receive this distinction. She was first chair in the New Jersey All-State Band and Orchestra during her high school years, and she was chosen as a soloist for the Julliard Preparatory Division graduation concert. ${ }^{16}$ Her performance at the Youth Congress in Toronto, Canada was the first of many international appearances as a soloist. ${ }^{17}$

After graduating from Julliard, Reinhart followed her brother to the University of Miami where he was enrolled as a medical student. She received a full scholarship to play in the orchestra under the baton of Fabian Sevitzky, and graduated cum laude with a Bachelor of Arts degree. ${ }^{18}$ While a student at Miami, Reinhart won the Hurricane Honey title in Miami's Orange Bowl, and then went on to win the 1961 National College Queen title in New York. An article in the Galveston Daily News reported that she continued to perform for the Salvation Army after winning her title, and demonstrated that as late as 1961, reportage on female artists still included information regarding their looks and dress. "The blue serge uniform neatly covers her 35-24-36

\footnotetext{
${ }^{15}$ Used with permission from Carole Dawn Reinhart.

${ }^{16}$ Card, "A Life of Firsts," 6.

17 "Carole Dawn Reinhart - Biographical Notes," International Trumpet Guild,

http://www.trumpetguild.org/news/news03/114areinhartbiog.htm (accessed 15 March 2009).

${ }^{18}$ Card, "A Life of Firsts," 7.
} 
figure and the black straw bonnet largely covers her light brown hair, but they don't cover her beauty." 19 In the same article, the nineteen-year-old Reinhart confirmed her willingness to capitalize on the novelty aspect of being a beauty queen as well as a professional trumpet player. "It is a novelty for a girl to play the trumpet, so maybe someone may want me. I'd prefer something like guest soloist for a high school band clinic or for churches. I figure that way I'll have more time than on the regular concert trail if I ever get married." 20

Reinhart received a Fulbright scholarship that took her to the Academy of Music in Vienna, Austria to study with Helmut Wobisch, where she was the first woman on a brass instrument to achieve the coveted Exam Maturity Degree, graduating with honors. She returned to New York to complete her education at the Juilliard School of Music where she performed as principal trumpet in the orchestra under the baton of Jean Morel. She earned both a Bachelor of Music degree and a Master of Science degree from Julliard. When asked about her prospects in obtaining orchestral work after leaving Julliard, Reinhart said,

There was a second trumpet audition coming up at the Metropolitan Opera while I was first trumpet with the Julliard Orchestra. My colleagues were invited to audition, but I wasn't. That was a day of realization. Having grown up in New Jersey, I wasn't interested in auditioning for an orchestra outside of the New York area. My main goal in music had always been to be able to earn a living with my trumpet. I still saw my best chances as a "novelty" in solo work, possibly doing more television shows, like my appearances on the Tonight Show with Skitch Henderson and Doc Severinsen, and with Al Hirt on Fanfare. But I always maintained standards in what I would or would not do - there had to be integrity and quality to the performances. ${ }^{21}$

After graduating from Julliard, Reinhart performed in the Radio City Music Hall Orchestra, in Leopold Stokowski's American Symphony Orchestra, and in the Orchestra de Camera. As a Getzen clinician, she performed approximately thirty solo engagements per year with high school and college bands. She also appeared with the Utah Symphony in Salt Lake City under the direction of Maurice Abravanel, and with the Miami Philharmonic. She continued with her Salvation Army solo and conducting work that included a tour to Australia, where she played the Haydn Trumpet Concerto in Eb at a live-telecast, open-air concert with an audience of over 100,000 in a natural amphitheater. ${ }^{22}$ When asked by a reporter in 1966 how she felt being a first-rate female performer in a "men's horn-blowing world," Reinhart responded, "Great, when it comes to touring England as a soloist with the all-men international Salvation Army Band. But most of the time I feel strange.",23

\footnotetext{
${ }^{19}$ Theodore Ediger, "National College Queen is Worker for Salvation Army," Galveston Daily News 24 September 1961, p. 30 (NewspaperARCHIVE.com).

${ }^{20}$ Ibid.

${ }^{21}$ Card, "A Life of Firsts," 12.

${ }^{22}$ Ibid., 10.

${ }^{23}$ Betsy Bliss, “A Salvation Army Volunteer, Too,” The Des Moines Register, 15 April 1966, p. 13

(NewspaperARCHIVE.com).
} 
In 1971, Reinhart resigned her steady job at Radio City Music Hall and moved to Berlin.

The move didn't go quite as I had expected, and in that first year in Berlin, I was often glad that I had only sublet my apartment in New York, and still had the option of returning. A Vienna schoolmate of mine, Manfred Stoppacher, was the lead trumpeter in the radio station RIAS Dance Orchestra. He was able to get me into the studio work scene. Berlin was a hub of the recording industry for Germany. I also filled in as first trumpet at the Deutsche Opera for one year when Konradin Groth went to the Berlin Philharmonic. ${ }^{24}$

She made recordings for Deutsche Grammophon and BASF with the Munich Philharmonic, German Bach Soloists, Amsterdam Chamber Orchestra, and Wuettemberg Chamber Orchestra, and also numerous radio recordings. Her performance venues included the "Golden Hall" of Vienna's Musikverein, the gothic Castle Hohenzollern where she played for a charity event hosted by Prince Louis Ferdinand (grandson of Kaiser Wilhelm), the Acropolis in Athens for Marie Jose (the last queen of Italy), and Royal Albert Hall for the final concert of the National Brass Band Championships. She performed for multiple festivals in Berlin, Paris, Salzburg, Vienna, Bordeaux, Jerusalem, Johannesburg, Cape Town, Tokyo, and Hong Kong. Other performances given in the United States were those with the New York Chamber Orchestra, the Lubbock Symphony, the Mid-East Band and Orchestra Director's Clinic, and the Mid-West Conference in Chicago. ${ }^{25}$

Reinhart married Manfred Stoppacher and, in 1983, accepted a full professorship at the University of Music in Vienna, Austria where she continues to teach today. In 1994, the Vienna University Press published her biography, Carole Dawn Reinhart-Aspects of a Career. She gave up her solo-performing career in 1996, after having performed for over fifty years.

The main reason was just dealing with the stress. I didn't want to have to do that anymore. I sacrificed a lot for my career. Most of the traveling I did was by myself since Manfred had his own career. When we'd been married for ten years, a girlfriend jokingly said that it was about the equivalent of three years since we'd been apart so much.

The idea of a vacation without planning practice time was extremely appealing. I had played concerts with the Vienna Chamber Orchestra on a trans-Atlantic cruise on the M.S. Europa from Panama to Hamburg. Coming out of the Panama Canal, while everyone else was up on deck, Manfred and I were playing duets to keep in shape. We could only take the half-day excursion to Tullum, not the full one to Chichén Itzá. While I do wish I had more opportunities to play in groups, I don't miss the "butterflies" of solo performances. ${ }^{26}$

Reinhart maintains an active schedule teaching her students at the university, giving master classes around the world, and serving as a juror for solo competitions. In 2003, she received the International Women's Brass Conference Pioneer Award, and the Austrian Cross of

\footnotetext{
${ }^{24}$ Card, "A Life of Firsts," 10.

${ }^{25}$ Ibid., 10-11.

${ }^{26}$ Ibid., 11.
} 
Honor for Science and Art, bestowed on her by the president of Austria. She was given the Award of Merit by the International Trumpet Guild in 2007.

In a 1976 interview for The Instrumentalist magazine, she shared her insights on being a professional trumpet player:

I think that there are three main qualifications for this type of work: the first would be excellent training on the instrument, second is to have as many various performing experiences as possible (this is what gives one "nerves" and the necessary confidence), and third, I would say is the strong desire-almost-to-obsession that makes it worthwhile in spite of the personal sacrifices and the times of disappointment. I think that musicianship or "taste" is also important, but this quality comes through training and experience and is a developing process, not an inborn one. Talent is probably the least important - it helps, but alone is nothing. The individual work involved far exceeds any natural abilities.

As a woman trumpeter, I have the advantage of being a novelty and often have been used for this purpose. It's much more difficult to be taken seriously. That can only be accomplished through performing not as well but better than men. ${ }^{27}$

27 "Career Alternatives in Music: Some Advice from Outstanding Women Musicians," The Instrumentalist 31, no. 4 (December 1976): 37. 


\section{Joyce Johnson-Hamilton ${ }^{28}$}

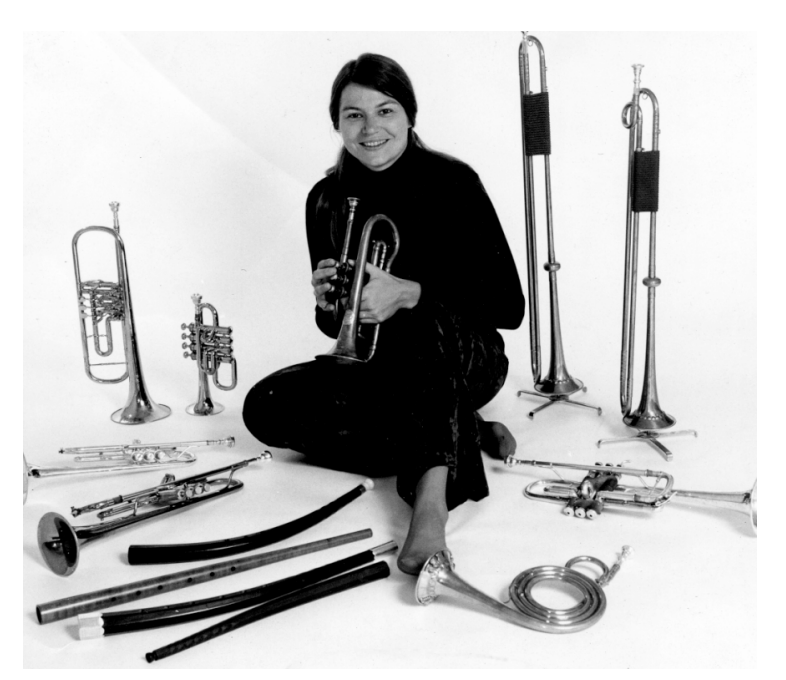

Figure 12. Joyce Johnson-Hamilton ${ }^{29}$

Joyce Johnson-Hamilton was born in Lincoln, Nebraska July 7, 1938 and grew up in Ralston, a small town southwest of Omaha. She was the third of four children, having two older sisters and one younger brother. When she saw a silver trumpet lying in a case at the home of a relative, she was drawn to the instrument. Students who wanted to participate in band did so through the Douglas County 4-H program, which she joined when she was eight years old. She remembered the elegant elderly band director saying, "This young lady has a perfect trumpet lip," and that reinforced her decision to choose trumpet. There were not many performing opportunities for her. The band rehearsed once a week and performed at county fairs in eastern Nebraska. They also played concerts, and marched in parades. She did perform a solo at eighth grade graduation, "Tramp, Tramp, Tramp," a piece that she had heard another cornet player perform so many times that she was able to learn it by ear. During her sophomore year, she played in the band at the newly created high school in her community.

Johnson-Hamilton began taking private lessons with Fred Elias when she was in the ninth grade. Elias was a friend of Herbert L. Clarke and taught his students to play using Clarke's style. Johnson-Hamilton worked through every page of the Arban Complete Conservatory Method with Elias, and worked through his own method book called The Buzz System. In addition to the cornet solos included in the back section of the Arban book, she performed Clarke solos including "The Debutante" and "Willow Echoes."

During a summer music camp at the University of Nebraska that she attended while in high school, Johnson-Hamilton realized that she wanted to pursue a profession in music as a conductor. At the camp, she sang in the chorus, played in the band and jazz band, and took

\footnotetext{
${ }^{28}$ All information from Joyce Johnson-Hamilton, interview with the author, 29 January 2009 and from bio provided by Ms. Johnson-Hamilton.

${ }^{29}$ Used with permission from Joyce Johnson-Hamilton.
} 
private lessons. Following high school graduation, she enrolled in the University of Nebraska, studying with Dean Killian and Jack Snyder during her undergraduate years, and with Dennis Schneider during her master's study. From her sophomore year forward, she was the principal trumpet in the orchestra. She also played in the concert bands and brass ensemble, and sang with the University Singers. Performing opportunities outside of the university included playing in the Lincoln Symphony and in church. During her summers, she attended the Aspen Music Festival where she studied with Robert Nagel and Bernard Adelstein.

After receiving her master's degree in 1962, Johnson-Hamilton obtained a job as a music teacher in a suburb of Omaha, and performed as an assistant principal with the Omaha Symphony, conducted by Joseph Levine. She performed the Bach B-minor Mass on piccolo trumpet for the symphony at a time when such trumpets were not commonly used in Nebraska. After teaching for three years, Johnson-Hamilton decided to leave her job and go to New York City to pursue performance opportunities.

That summer (1965), she returned to the Aspen Music Festival for the sixth time with the intention of networking with the performers and instructors in an attempt to obtain work. Maestro Jacques Singer of the Portland Symphony visited orchestra rehearsal one afternoon and requested a personnel recommendation from Robert Nagel for a trumpet opening he was trying to fill. Nagel suggested Johnson-Hamilton, so during a break in the rehearsal, she auditioned for him outside of the rehearsal tent, playing "Dance of the Ballerina" from Petroushka. She played it so well that he hired her on the spot. Instead of moving to New York City as she had originally intended, she moved to Portland, Oregon where she became the principal trumpeter for the Portland Symphony. One highlight of her three seasons in Portland (1965-1969) was performing for guest conductor, Igor Stravinsky. He was in ill health at the time and unable to conduct the longer pieces, so Robert Craft assisted him. The orchestra performed Stravinsky's Symphony of Winds, the Pulcinella Suite, and Beethoven's first symphony, a favorite of Stravinsky's.

The San Francisco Symphony announced auditions for the assistant principal position in the spring of 1968. The orchestra was using the new technique of holding screened auditions. The conductor was resistant to hiring anyone he could not see, so he refused to hire anyone. Johnson-Hamilton auditioned for the position on three separate occasions, advancing to the final round each time. Finally, in the third set of auditions, Johnson-Hamilton was the only one to advance, and she was hired. She believed that the conductor was not happy at having hired a woman. Johnson-Hamilton performed in the assistant principal position with San Francisco for one season but knew that her tenure with the orchestra was going to be short-lived. She auditioned for other orchestras, and decided to pursue her doctoral studies. She obtained a graduate fellowship at Stanford University as a student in baroque and renaissance performance practice. She continued with the San Francisco Symphony and the opera, performing when they needed a fourth or back stage trumpet.

Baroque and renaissance music was becoming quite popular in San Francisco, and many artists were returning to the original performance practice of playing on the natural instruments. Johnson-Hamilton began performing on the natural, valveless trumpet, learning the technique and style by studying original and other musicological sources, and by attending concerts given 
by musicians such as Edward Tarr. She played a coiled D trumpet and a Meinle and Lauber straight trumpet with the thumbhole.

She continued her orchestral playing, serving as the principal trumpet in the Oakland Symphony for four seasons (1971-76), the San Jose Symphony (1976-1980), and the Cabrillo Festival Orchestra (for several summers) under the baton of Carlos Chávez. She founded the Sinfonia of Northern California in 1974, which specialized in performing seventeenth and eighteenth century orchestral music. In 1978, she was invited to perform a solo recital at the International Trumpet Guild Conference in Madison, Wisconsin, and in 1993, she was a featured soloist at the First International Women's Brass Conference.

Midway through her study at Stanford, she switched concentrations to conducting, opening another facet of her musical career. In 1972, Harold Farberman, principal conductor of the Oakland Symphony Orchestra, appointed her as one of his assistant conductors. When she won conducting positions in both the Napa Valley Symphony and the Diablo Symphony in the late 1970s, she gave up full-time trumpet playing, restricting her performances to special solo engagements. She was a trumpet and conducting instructor at Stanford University beginning in the late 1970s, but eventually resigned to focus on her conducting. In 1989, she left the Napa Valley Symphony, resumed her teaching work at Stanford, and continued her study of baroque trumpet.

At present, Johnson-Hamilton is in her thirtieth season conducting the Diablo Symphony, and is a specialist on both the renaissance cornetto and the baroque trumpet. She has performed with the Pacific Baroque Orchestra of Vancouver (British Columbia), the Orchestra of the $17^{\text {th }}$ Century (Washington, D.C.), the Northwest Chorale (Seattle), the California Bach Society (Palo Alto), the Women's Antique Vocal Ensemble (San Francisco), the Carmel Bach Festival (California), the Philharmonia Baroque and Magnificat (San Francisco), Whole Noyse (Palo Alto), and as a featured soloist with the Los Angeles Baroque Orchestra.

One of the many interesting experiences in her musical career was with the Seoul Philharmonic.

I had a manager for a period of time, and the only engagement I ever had from him was conducting the Seoul Philharmonic in Seoul, Korea. They wanted a western woman conductor who could conduct, perform on an instrument, and do musical arranging. I was perfect. I was exactly the person they wanted. It was so exotic to feature a woman as a conductor; they knew their audiences would really go for that. And it was true- the concerts were sold out! I did many symphonic pops arrangements, I played trumpet solos, and I conducted the orchestra. They asked me back eleven times. That was one experience where being a woman was definitely an advantage. 


\section{Marie Speziale $^{30}$}

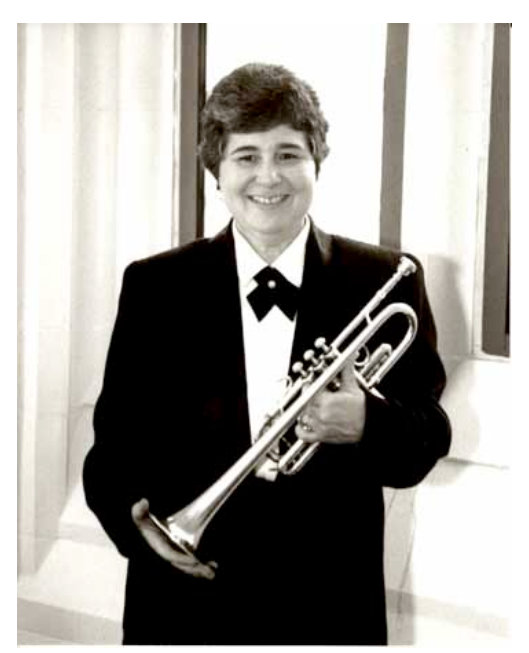

Figure 13. Marie Speziale ${ }^{31}$

Marie Speziale was born in Brooklyn, New York on April 4, 1942, but grew up in the Latin district (Ybor City) in Tampa, Florida. She began playing the cornet when she was ten years old, having seen the instrument, and heard it played by the Cuban musicians who played in a band with her father. Bob Price, a school band director, was her first cornet instructor, and taught her using the Arban Complete Conservatory Method. She performed with her father's band for the first time when she was eleven years old. When she was sixteen, she joined the musicians union and began playing union jobs. She also performed with a small group of musicians (Three Queens and a King) for Date on 8, a local television show on an NBC affiliate. That exposure led to a solo appearance on the $N B C$ Today Show with Dave Garroway.

Speziale attended the Cincinnati College-Conservatory of Music, where she was principal trumpet in the orchestra, brass choir, wind ensemble, and band beginning in her freshman year. During her junior and senior years in college, she was a regular substitute with the Cincinnati Symphony Orchestra, performing with her teacher from the Conservatory, Eugene Blee. A versatile player, Speziale performed all styles of music as a freelancer in the Cincinnati area. The musicians union provided her with many commercial performance opportunities, including as a regular performer on Paul Dixon's variety television show.

After she graduated in 1964, Speziale auditioned for and won the associate principal trumpet position with the Cincinnati Symphony Orchestra, and performed in that position for thirty-two years until her retirement from the orchestra in 1996. She also performed as the associate principal trumpet with the Cincinnati Opera Orchestra, Cincinnati May Festival Orchestra, Cincinnati Ballet Orchestra, and the Cincinnati Pops Orchestra. She performed under many conductors including Igor Stravinsky, George Szell, Leonard Bernstein, Aaron Copland,

\footnotetext{
${ }^{30}$ All information is taken from Marie Speziale interview with the author, 23 December 2008 unless otherwise noted.

${ }^{31}$ Used with permission from Marie Speziale.
} 
Eugene Ormandy, Eric Leinsdorf, and Max Rudolf. ${ }^{32}$ For one season, she performed as acting principal trumpet but turned down the permanent position when it was offered to her.

I had many different interests at the time. I was doing the pops concerts with the orchestra, playing in the Symphony Jazz Septet, and teaching at Miami University (Oxford, $\mathrm{OH}$ ). I wanted to keep doing those things, and felt that I would have to give up some of those responsibilities in order to meet the demands of a principal position. The associate job afforded me some principal playing while still allowing me to do a variety of things. I made the decision to stay in the associate position. ${ }^{33}$

Speziale was known as "that swingin' girl trumpeter" for her performances with the Symphony Jazz Septet. ${ }^{34}$

The group started as a quartet. The Symphony Jazz Quartet was born in Bombay, India about halfway through the CSO's ten-week, 1966 World Tour. There was a combo playing at the Taj Mahal Hotel where the orchestra was staying. After one of our concerts, some of us decided to sit in with the group. We realized instantly that there was a strong chemistry among those of us from the CSO. We had so much fun playing together that evening that we decided to keep the group going when we got back home. Erich Kunzel was just thrilled to have this group in the orchestra. He would feature us a lot on his CSO Pops concerts. We enjoyed tremendous exposure in the tri-state area. Within a year of the group's inception, we were appointed ensemble-in-residence at the College-Conservatory of Music at the University of Cincinnati. ${ }^{35}$

During her tenure with the orchestra, Speziale served on the faculty as a trumpet instructor at the Conservatory (1964-1972), on the faculty at Miami University of Ohio (197379), and then returned as an Adjunct Associate Professor to the Conservatory (1979-2002). After her retirement from the $\mathrm{CSO}$, she continued to teach at $\mathrm{CCM}$ and also taught full-time at Indiana University in Bloomington (1999-2003), maintaining residences in both Cincinnati and Indianapolis. ${ }^{36}$

She appeared as a soloist with the Cincinnati Symphony Orchestra, Cincinnati Pops Orchestra, Cincinnati Chamber Orchestra, with Duke Ellington, with Dave Brubeck on the Johnny Carson NBC Tonight Show, on the Cincinnati Symphony Orchestra European tours, and at the Interlochen Arts Academy, among others. She served as a clinician, coach, or adjudicator for numerous master classes and conferences in Europe, Japan, and the United States, including the International Women's Brass Conference, the International Trumpet Guild, the Summit Brass Mendez Institute, the New World Symphony, the International Trumpet Competition, and the Cincinnati College-Conservatory Music's Opera Theatre and Music Festival of Lucca (Italy).

\footnotetext{
32 "Marie Speziale: Professor of Trumpet, and Chair, Brass," The Shepherd School of Music, Rice University, http://music.rice.edu/facultybios/speziale.html (accessed 17 March 2009).

${ }^{33}$ Karen Gustafson, "Marie Speziale: Performer, Teacher, and Pioneer," International Trumpet Guild Journal 26, no. 4 (June 2002): 9.

34 “'Orchestra Profile," Cincinnati Symphony Orchestra Program, 1970-71 Season, p. 533.

${ }^{35}$ Gustafson, 10.

${ }^{36}$ Ibid., 8.
} 
She was one of six Americans (and the only woman) to be invited to perform in the first Super World Orchestra at the Tokyo International Music Festival. ${ }^{37}$

In 2002, she moved to Texas and accepted a position as Professor of Trumpet at the Shepherd School of Music at Rice University. She continues to perform with the Houston Grand Opera, and often in the Houston Symphony Orchestra and the Houston Ballet Orchestra

\section{Susan Slaughter}

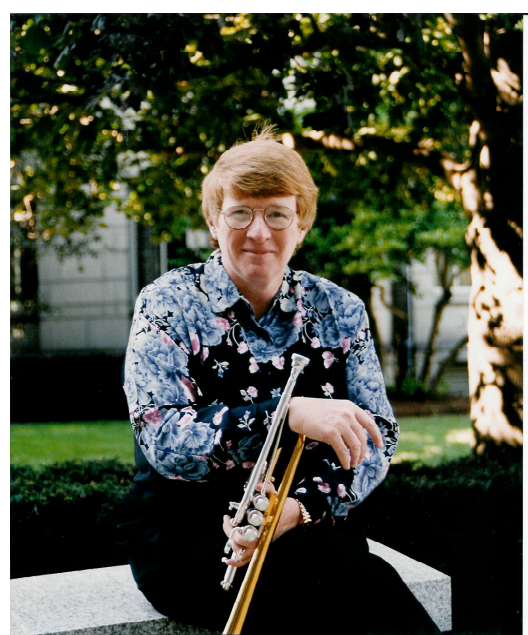

Figure 14. Susan Slaughter ${ }^{38}$

Born in McCordsville, Indiana, Susan Slaughter began learning trumpet at age ten when the first band program was instituted at her grade school. She chose the trumpet because she was attracted to the way it sounded, having heard the instrument in church and on television. Her instructors during her school years were encouraging of her efforts except in one area, the high school stage band. Girls were not allowed to play in that band, but that did not stop her from performing as a substitute the one time she was asked. ${ }^{39}$ While attending high school, she studied privately at the Jordan Conservatory in Indianapolis, Indiana. ${ }^{40}$ Her first experience playing in an orchestra occurred during a summer camp she attended at Indiana University following her tenth-grade year. ${ }^{41}$

After graduating from high school, Slaughter chose to attend Indiana University where she performed in the orchestra. Of the eighty trumpet students, she was the only female majoring

\footnotetext{
37 "Marie Speziale: Professor of Trumpet, and Chair, Brass."

${ }^{38}$ Used with permission from Susan Slaughter.

${ }^{39}$ Gene Pokorny, "Interview with Susan Slaughter," International Women's Brass Conference Newsletter 1, no. 1 (June 1992): 3.

${ }^{40}$ Sherrie Tucker, "Susan Slaughter," Windplayer: for Woodwind and Brass Musicians 10, no. 3 (1993): 25.

${ }^{41}$ Kara Krekeler, “A Brassy Woman,” West End Word, 7-13 Mar 2007, p. 11.
} 
in performance. When asked about working with the other male students, she said, "I learned that the smartest thing to do was to keep your mouth shut and let your instrument do the talking. They can put you down because you're a woman, but they can't put down your playing.,

She graduated in 1967 with a Bachelor of Music degree, and received the much-coveted Performer's Certificate. Her instructor while at Indiana was Herbert Mueller. In 1966 and 1968, she attended the Aspen Festival, studying with Robert Nagel. In 1969 she received a fellowship to Tanglewood and played in the orchestra. ${ }^{43}$ Her ultimate professional goal was to obtain a fulltime orchestral position. "I just loved playing in the orchestra and I just felt that this was what I'd like to do, any position at all in any orchestra. It didn't matter how good the orchestra was." 44

Prior to her graduation from Indiana, she mailed over thirty letters to different orchestras with the intent of obtaining an invitation to audition. She did not receive any responses, so she began signing her letters with her initials rather than her first name. This resulted in the receipt of several invitations. Slaughter auditioned for three different orchestras: the Milwaukee Symphony, the North Carolina Symphony, and the Toledo Symphony. ${ }^{45}$

I played lousy at Milwaukee - that was my first. As I was flying home I thought, "What am I doing in this business? I can't play!" I had two more auditions lined up and I thought, "Well, I'll just take them. I mean, it's probably hopeless, but I'll just take them. 46

She won the principal trumpet position in the Toledo Symphony, maintaining the position for two seasons, 1967-1969. In March 1969, wanting to keep her auditioning skills sharp, Slaughter took an audition for the fourth chair opening with the St. Louis Symphony, and won the position. ${ }^{47}$ In a conversation with one of her string colleagues years later, she discovered that when he saw her enter the stage to audition, he started to leave because he saw that she was a woman. After hearing her play a few notes, he decided to stay and listen. ${ }^{48}$ She initially had reservations about accepting the position because she really enjoyed playing first with Toledo, but her instructor encouraged her to make the move, and the pay increase was enticing as well. Slaughter initially felt a little odd about doing less work for more money, given that the principal chair in Toledo paid $\$ 2,500$, while fourth chair in St. Louis paid $\$ 9,000 .{ }^{49}$

Three weeks prior to the beginning of the 1972 season, the principal trumpeter resigned and Slaughter was called upon to be the acting principal. Her first concert included a Weber overture, the Strauss Suite from Le Bourgeois Gentihomne, and the Bartok Concerto for Orchestra. Her second concert, given the following week, included the Brahms Symphony no. 3,

\footnotetext{
${ }^{42}$ Deg Gray, "She Can't Recall Why She Chose Trumpet," The Lincoln Star, 3 November 1975, p. 5.

43 "Saint Louis Symphony Orchestra's Principal Trumpet: Susan Slaughter," Woodwind World-Brass \& Percussion 15, no. 1 (January 1976): 36.

${ }^{44}$ Krekeler, 11.

${ }^{45}$ Tucker, "Susan Slaughter," 25.

${ }^{46}$ Ibid.

${ }^{47}$ Ibid., 25-6.

${ }^{48}$ Pokorny, 3.

${ }^{49}$ Tucker, "Susan Slaughter," 26-7.
} 
Rachmaninoff's Rhapsody on a Theme of Pagannini, and Scriabin's Poem of Ecstasy. ${ }^{50}$ The orchestra could not decide whether to hire her or a gentleman from the Israel Philharmonic as the permanent principal, so they had both musicians serve as acting co-principals, alternating halves of the programs. This went on for four months until December, when they finally offered Slaughter the principal position and she became (and still is as of 2009) the first and only female principal trumpeter in a major symphony orchestra. ${ }^{51}$

Initially, she met with some resistance from the trumpet section, who experienced difficulty in taking orders from a young woman. "We just worked around that. We just talked about it. [She told them] 'I know this is an adjustment for you, and let's not make a big deal out of it.' For the most part, I think that taking that approach worked very well., ${ }^{, 52}$

Slaughter has performed as a soloist with the St. Louis Symphony and as principal trumpet on their recordings made since 1974. She has performed duets with Wynton Marsalis, Kathleen Battle, Christine Brewer, Doc Severinsen, and Al Hirt. As part of the St. Louis Symphony Orchestra outreach program, she has organized several large-scale ensembles to perform with the orchestra including seventy-six amateur trombone players on "76 Trombones" (1999), one hundred amateur trumpet players on "Trumpeter's Holiday" (2000), and one hundred amateur brass players to perform in "Top Brass" (2001). Slaughter was the featured soloist on the "Trumpeter's Holiday" and "Top Brass" concerts, performing favorite Harry James tunes on the latter. ${ }^{53}$ Gene Pokorny, tubist with the Chicago Symphony Orchestra said, "No one has more integrity or leads a brass section better than Susan Slaughter. ${ }^{, 54}$

An avid St. Louis Cardinals fan, she has performed the National Anthem and God Bless America on an annual basis at their baseball games since the 1980s. This experience led to an invitation from baseball commissioner Fay Vincent to perform the National Anthem at Game 3 of the 1991 World Series, played in Atlanta between the Atlanta Braves and the Minnesota Twins. In 2002, she performed Taps for the memorial service at Busch Stadium as well as for the burial at Jefferson Barracks Cemetery of Jack Buck, a radio sportscaster for the Cardinals. ${ }^{55}$

Slaughter has conducted master classes for numerous organizations including the National Orchestra Institute, the Teton Music Festival, the International Trumpet Guild, the National Trumpet Symposium, the Marrowstone Music Festival, Northwestern University, and the Peabody School of Music at Johns Hopkins University. In 1989, Slaughter spent her first summer as an instructor at the Grand Teton Orchestra. The resulting interactions with her female students led to the idea of establishing a women's brass organization.

It became clear to me that women brass musicians knew very little about each other. They were also hesitant to communicate with each other, and were therefore missing a very important opportunity to support one another, as well as nourish and inspire younger

\footnotetext{
${ }^{50}$ Pokorny, 3.

${ }^{51}$ Ibid.

${ }^{52}$ Krekeler, 11/13.

${ }^{53}$ Susan Slaughter Biography obtained from and used with permission from Susan Slaughter.

${ }^{54}$ Tucker, "Susan Slaughter," 27.

${ }^{55}$ Susan Slaughter Biography obtained from and used with permission from Susan Slaughter.
} 
brass musicians who might want to pursue a professional career. The other observation I made concerned the established brass organizations. Each of their conferences rarely, if ever, featured a female or African American artist. Why would they ignore representing every segment of their membership when ten to fifty percent of their members were minorities? The excuse "we do not know anyone to invite" was no longer acceptable to me. ${ }^{56}$

Slaughter contacted many of her brass colleagues and then decided to send a survey to all of the female brass players she could locate. Using directories from many different organizations, she sent 1500 surveys and received roughly 500 responses. Of those returned, ninety percent indicated support for creating a women's brass conference. ${ }^{57}$ Buoyed by the overwhelming positive response, in 1991 she founded the International Women's Brass Conference. With the help of Dr. Rebecca Staup, an experienced arts manager, Slaughter formed a board of directors, and they met for the first time in February 1992 in Washington, D. C. Their long range plans included presenting a conference every three to five years that would feature prominent female and male artists, printing a newsletter twice per year, organizing an allwomen's brass ensemble, producing compact discs, creating a directory of female brass musicians, and honoring pioneer women in the field. ${ }^{58}$ The mission statement of the organization was (and continues to be) to provide opportunities that will educate, develop, support, and inspire all women brass musicians who desire to pursue professional careers in music. ${ }^{59}$

The first conference was hosted by Slaughter in May 1993 at Washington University in St. Louis. ${ }^{60}$ Monarch Brass, an all-women's ensemble, was formed, and in addition to performances at the five conferences held to date (1993, 1997, 2000, 2003, 2006), they toured the United States in 1996 and Italy in 1999. In June 2000 they produced their first CD. Fourteen women have been honored as Pioneers including nine trumpeters: Clora Bryant, Nadine Jansen, Betty O'Hara (also a trombonist), Carole Dawn Reinhart, Jane Sager, Betty Scott, Leona May Smith, Bette Eilers, and Ruth Still. Other ensembles have been formed as a result of connections made by attendees of the conferences. One unique group is $\mathrm{USB}_{21}$ (the United States Brass $21 \mathrm{st}$ Century), an ensemble comprised of female musicians from the military service bands. ${ }^{61}$ Slaughter established the popular St. Louis Holiday Brass Concerts as a fundraising effort in support of the conference, raising over $\$ 300,000$ in fourteen years. ${ }^{62}$

In addition to founding the International Women's Brass Conference, Slaughter has served on the board of directors for the International Trumpet Guild, the St. Louis Volunteer Lawyers and Accountants for the Arts, and the St. Louis Women's Chorale. Some of her more notable performances include for the National Museum of Women in the Arts concert series in Washington, D.C., as a soloist at the Marrowstone Music Festival (Seattle), and with the

\footnotetext{
${ }^{56}$ Susan Slaughter, “The IWBC at 10 Years: A Look Back," International Women's Brass Conference Newsletter 9, no. 2 (Winter 2003): 6.

${ }^{57}$ Ibid.

${ }^{58}$ Ibid.

${ }^{59}$ Krekeler, 13.

${ }^{60}$ Ibid.

${ }^{61}$ Slaughter, "The IWBC at 10 Years," 6.

${ }^{62}$ Susan Slaughter Biography obtained from and used with permission from Susan Slaughter.
} 
Women's Philharmonic (San Francisco). She was a contributor to Arnold Jacobs, The Legacy of a Master by M. Dee Stewart, and was nominated for Ladies Home Journal Woman of the Year. She is the recipient of several rewards including the YWCA's Special Leadership Award in the Arts, the American Federation of Musicians (Local 2-197) Owen Miller Award for Loyalty, Dedication and Fairness in Actions and Deeds, and the 2007 Excellence in the Arts awarded by the St. Louis Arts and Education Council. ${ }^{63}$

Slaughter continues to perform in the St. Louis Symphony, as of 2009 having held the position for thirty-seven years, an impressive tenure for any principal trumpeter. When she thinks about retirement, one thing to which she looks forward is the possibility of obtaining season tickets to the Cardinals games, and perhaps traveling to other stadiums throughout the country to watch the team play. ${ }^{64}$

\section{Barbara Butler ${ }^{65}$}

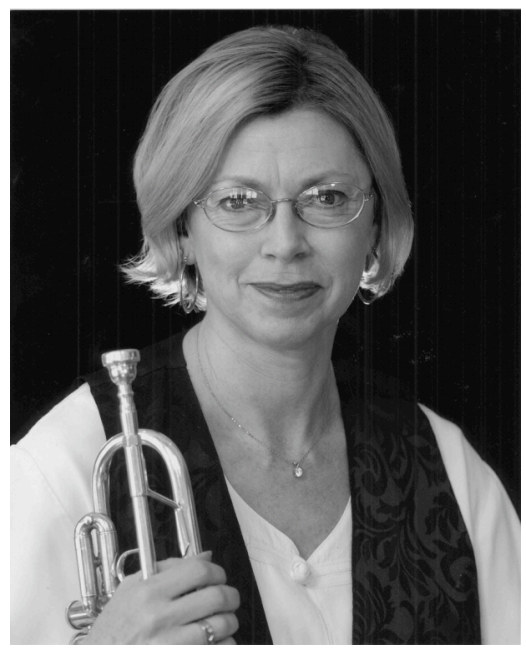

Figure 15. Barbara Butler ${ }^{66}$

Barbara Butler was born in Waterloo, Iowa and grew up in Cedar Falls, Iowa. She began playing the trumpet when she was in the fourth grade, learning music in her public school band program, and by taking lessons at the local music store. Joining the union at age fourteen, she played with the American Legion Band during the summer. She began taking lessons with Dr. David Kennedy, the horn instructor at the University of Northern Iowa, who encouraged her to participate in various solo competitions, many of which she won. These provided her the opportunity to perform as a soloist with a variety of orchestras throughout the state.

\footnotetext{
${ }^{63}$ Ibid.

${ }^{64}$ Krekeler, 13.

${ }^{65}$ All information taken from Barbara Butler, interview with author, 3 March 2009.

${ }^{66}$ Used with permission from Barbara Butler.
} 
Butler attended Interlochen Summer Arts Camp during the summer of her junior and senior years of high school $(1969,1970)$, where she discovered she liked being around people who were very serious about music. She entered St. Olaf's College in the fall of 1970 as a comparative literature major, but was encouraged by her trumpet instructor, Ron Hasselman, to transfer to Northwestern University, and study music full time. She transferred and began taking lessons with both Vincent Cichowicz and Adolph Herseth. She played in the Chicago Civic Orchestra (the training orchestra for the Chicago Symphony Orchestra) and during the summers, she attended the Tanglewood, Aspen, and the Pierre Monteux festivals.

Upon her graduation in 1974, Butler won the principal trumpet position with the Grant Park Symphony (a summer orchestra in Chicago), and then won the co-principal position with the Vancouver Symphony in Canada. She had also auditioned for the Chicago, Cincinnati, Montreal, and Toronto Symphonies, competing with artists such as Phil Smith, Jim Thompson, and Phil Collins. During her first summer with Grant Park, she performed in the second chair position while the conductors auditioned two of the interior section players who had expressed interest in the principal position, yet had not taken the audition. The following summer, she assumed the principal chair.

Butler played as an "extra" with the Chicago Symphony Orchestra where she met her future husband, trumpet player Charles Geyer. They both were active performers but were able to maintain a long distance relationship for several years. Butler spent the orchestral season in Vancouver while Geyer served as principal trumpet with the Houston Symphony. They married in 1978, and wanting to be closer together, they considered several job offers that would allow them to do so. In 1980, they accepted teaching positions at the Eastman School of Music. In addition to the teaching and performance activities generated by their positions at Eastman (including the Eastman Brass Quintet), they maintained their contacts in Chicago, performing together and as soloists, with Music of the Baroque (Chicago) and the Chicago Chamber Musicians.

In 1998, Vincent Cichowicz retired from the trumpet teaching position at Northwestern, and the university offered positions to the husband-and-wife team. Having had a baby, the travel between New York and Chicago was becoming a hardship for Butler and Geyer, so they accepted the positions at Northwestern and moved to Chicago. Since 1985, both musicians have served as co-principals in the trumpet section at the Grand Teton Music Festival Orchestra in Wyoming. Throughout her career, Butler has performed as a guest artist with the Chicago Symphony Brass Ensemble, the International Women's Brass Conference, the Minnesota Symphony's Rug Concerts, the International Trumpet Guild, and New York's Mostly Mozart series. She has toured extensively with Geyer, and given performances in Italy, Japan, Spain, Finland, Switzerland, and Canada. She continues to teach at Northwestern University. 


\section{Chapter 6 - Summary, Conclusions, and Recommendations for Further Study}

The oddity of the woman brass musician is an ongoing myth. Each girl who has embarked on that path has done so believing that she is the first, most remarkable and only ever to attempt such a feat. The truth is that women have performed on brass instruments throughout history. Ever since the fifteenth century, society's leaders have acknowledged women brass players, praising their technical virtuosity, superior tone quality, and musical expressiveness. However, the annals of history have the unfortunate habit of forgetting about women.- Ramona Galey (trumpeter with the Women's Philharmonic in Los Angeles) ${ }^{1}$

Opportunities did exist for women to perform, first on the cornet and then the trumpet. During the latter 1800's, while the band movement was at its' peak, female cornetists performed as part of family bands, as soloists, and as part of the all-women bands. Often, the artists toured as part of an entertainment troupe or company, and were called upon to do more than play the cornet, as in the case of Georgie Dean Spaulding performing on the harp and singing. The novelty aspect of a woman playing the cornet was a big draw, and often the more novel artists (such as "Petite" Bertha Noss) were given top billing.

The cornet soloists performed in recitals or appeared with the professional bands and orchestras at festivals, fairs, and outdoor concerts. Several artists toured with their husbands or a male partner, including Laura Edwards Prampin and Etta Minor, who performed for minstrel shows. These women retired when their husbands stopped performing or had passed away. The cornet soloists, such as Anna Theresa Berger and Alice Raymond, performed the same music as their male counterparts, which included the cornet solos and popular songs that were fashionable at the time. While some artists maintained their performing careers throughout their lives, others retired when they married, and turned to teaching as a source of income, as in the case of Browne Greaton and Florence Louise Horne. Teaching was a lucrative profession, one that Leona May Smith encouraged women to pursue in order to supplement their performance income.

Because it was not socially acceptable for women to perform in the same ensembles as men, unless they were family members, women formed their own groups to meet their need for a performance medium. The women's bands and orchestras provided an opportunity for female cornetists and trumpeters to learn the standard repertoire and gain valuable performance experience. The women's bands were often modeled after the leading military bands of the time, performing the same music, and wearing military style uniforms. Many of these ensembles, such as the Boston Fadettes, strived to be perceived as elite ensembles by using their marketing materials to promote their high ideals and pedigree, and also by paying close attention to how they dressed. MacLeod asserted that "The successful woman performer was one who could play like a man-but not appear unfeminine."2 The professional women's symphony orchestras were usually founded by women conductors or instrumentalists, and performed the same repertoire as the men's ensembles.

\footnotetext{
${ }^{1}$ Lisa Maloof, "Focus Story: Women in Brass," the Women's Philharmonic Newsletter (Spring 1998): 9.

${ }^{2}$ Macleod, Beth Abelson Macleod, “'Whence Comes the Lady Tympanist?' Gender and Instrumental Musicians in America, 1853-1990," 293.
} 
Chamber ensembles were another medium that provided performance income for trumpeters. In the course of her career, Edna White formed several female quartets with varying instrumentation that performed for church services and special occasions. An offshoot of one of Edna's groups in New York City was the Gloria Trumpeters, led by Katherine Rankin. The brass quartets were often used in outdoor ceremonies, most likely due to the ability of the instruments to project sound over great distances. The formation of these chamber ensembles as well as the all-female orchestras and bands created an autonomy that perhaps kept the female performers isolated on a professional level from their male counterparts. This autonomy may have allowed these performers not only to avoid being perceived as a threat by the male artists in most cases, but also allowed them to maneuver the expectations of conventional society that believed a woman's "duty to humanity" did not include playing certain instruments.

World War II provided some opportunities for women to perform in orchestras and in the all-female military bands. Female trumpet players followed the trend of women musicians in general gaining positions in major orchestras, but at a much slower pace. The feminist movement of the 1960s and the ICSOM demands helped to open doors, as did education, equal opportunity, Title IX, and a heightened sense of political correctness. Myers and Etaugh asserted that "When entering professions that previously have been dominated by males, women usually first appear in lower-status organizations and positions." "3 This is certainly the case for female trumpeters (and low brass players) gaining acceptance into symphony orchestras. From the 1930s until present day, they appear on the rosters of many secondary orchestras, but there are still only a few holding permanent positions in the major ensembles. An examination of the musician rosters for United States symphony orchestras having an annual operating budget of at least ten million dollars (according to Musical America, 2000 edition) reveals a vast difference in the number of male trumpeters versus their female counterparts. Examination of the differing sections provides an interesting comparison as well (see Table 13).

\footnotetext{
${ }^{3}$ Douglas W. Myers and Claire Etaugh, "Women Brass Musicians in Major Symphony Orchestras: How Level is the 'Playing Field?"' International Alliance for Women in Music Journal 7, no. 3 (2001): 28.
} 
Table 13. Wind Personnel in Selected U.S. Orchestras (1999-2000 season) ${ }^{4}$

\begin{tabular}{|c|c|c|c|c|c|c|c|}
\hline \multicolumn{8}{|c|}{$\begin{array}{l}\text { Key: } x / y \\
x=\text { number of females in the section } \\
y=\text { total number of players in the section } \\
\text { N.A. = no listing available }\end{array}$} \\
\hline Orchestra & Flutes & Oboes & Clarinets & Bassoons & F Horns & Trumpets & Low Brass \\
\hline Atlanta & $1 / 4$ & $2 / 4$ & $1 / 4$ & $1 / 4$ & $1 / 5$ & $0 / 3$ & $0 / 4$ \\
\hline Baltimore & $3 / 4$ & $2 / 4$ & $0 / 4$ & $1 / 4$ & $2 / 6$ & $1 / 4$ & $0 / 5$ \\
\hline Boston & $2 / 4$ & $0 / 4$ & $0 / 4$ & $0 / 4$ & $0 / 6$ & $0 / 3$ & $0 / 4$ \\
\hline Chicago & $2 / 4$ & $0 / 4$ & $1 / 4$ & $0 / 4$ & $1 / 6$ & $0 / 4$ & $0 / 4$ \\
\hline Cincinnati & $2 / 3$ & $0 / 4$ & $0 / 4$ & $0 / 4$ & $0 / 6$ & $0 / 4$ & $0 / 4$ \\
\hline Cleveland & $2 / 4$ & $1 / 4$ & $1 / 4$ & $0 / 4$ & $0 / 6$ & $0 / 4$ & $0 / 5$ \\
\hline Dallas & $2 / 3$ & $1 / 3$ & $0 / 4$ & $0 / 3$ & $2 / 6$ & $0 / 4$ & $0 / 4$ \\
\hline Detroit & $1 / 4$ & $2 / 4$ & $0 / 5$ & $1 / 4$ & $0 / 6$ & $0 / 4$ & $0 / 4$ \\
\hline Indianapolis & $3 / 3$ & $1 / 3$ & $0 / 3$ & $0 / 3$ & $1 / 5$ & $0 / 3$ & $0 / 4$ \\
\hline Los Angeles & $3 / 3$ & $2 / 4$ & $2 / 4$ & $2 / 4$ & $1 / 5$ & $0 / 3$ & $0 / 5$ \\
\hline Milwaukee & $3 / 3$ & $1 / 4$ & $1 / 3$ & $2 / 3$ & $0 / 5$ & $0 / 3$ & $0 / 4$ \\
\hline Minnesota & $3 / 4$ & $2 / 4$ & $0 / 4$ & $0 / 4$ & $1 / 5$ & $0 / 3$ & $1 / 4$ \\
\hline National S. O. & $3 / 4$ & $2 / 4$ & $0 / 4$ & $0 / 4$ & $2 / 5$ & $0 / 4$ & $0 / 5$ \\
\hline New Jersey & N.A. & N.A. & N.A. & N.A. & $4 / 4$ & $0 / 3$ & $0 / 4$ \\
\hline New York & $3 / 4$ & $1 / 4$ & $1 / 4$ & $1 / 4$ & $0 / 6$ & $0 / 4$ & $0 / 5$ \\
\hline Oregon & $3 / 3$ & $1 / .3$ & $1 / 3$ & $0 / 3$ & $1 / 5$ & $1 / 3$ & $0 / 4$ \\
\hline Philadelphia & $1 / 4$ & $1 / 4$ & $0 / 4$ & $2 / 4$ & $1 / 6$ & $0 / 4$ & $0 / 5$ \\
\hline Pittsburgh & $2 / 4$ & $1 / 4$ & $0 / 3$ & $1 / 4$ & $0 / 6$ & $0 / 4$ & $1 / 5$ \\
\hline St. Louis & $3 / 4$ & $3 / 4$ & $1 / 4$ & $1 / 4$ & $0 / 5$ & $1 / 4$ & $0 / 5$ \\
\hline San Francisco & $3 / 4$ & $2 / 4$ & $0 / 4$ & $0 / 4$ & $2 / 6$ & $0 / 4$ & $0 / 4$ \\
\hline Seattle & $2 / 3$ & $0 / 3$ & $1 / 3$ & $0 / 3$ & $0 / 5$ & $0 / 3$ & $0 / 4$ \\
\hline Utah & $1 / 3$ & $1 / 3$ & $0 / 4$ & $1 / 3$ & $1 / 5$ & $0 / 3$ & $2 / 4$ \\
\hline Totals & $48 / 76$ & $26 / 79$ & $10 / 80$ & $13 / 78$ & $20 / 120$ & $3 / 78$ & $3 / 94$ \\
\hline$\%$ Female & 63.2 & 32.9 & 12.5 & 16.7 & 16.7 & 3.8 & 3.2 \\
\hline
\end{tabular}

Further research is needed to determine why there is such a disparity in the number of men versus the number of women being hired into the brass sections of these orchestras. An examination should be made to determine if females are training to be professional trumpet players. Does the high percentage (63.2\%) of female flautists in orchestras compared to the much lower percentage (3.8\%) of trumpeters indicate that certain instruments are still perceived to be more masculine or feminine? How many girls who join beginning band classes play the trumpet? How many continue to play in their high school band programs? How many enter undergraduate programs as music majors, and how many graduate with music degrees?

\footnotetext{
${ }^{4}$ Douglas W. Myers and Claire Etaugh, "Women Brass Musicians in Major Symphony Orchestras: How Level is the 'Playing Field?"' IAWM Journal 7, no. 3 (2001): 29.
} 
Another study could be done to determine whether or not women are taking auditions for open trumpet positions in symphony orchestras. If so, how many as compared to men? How many positions have been open and filled, and how many were filled by men compared to women? Something to consider would be whether or not female trumpet players desire to have orchestral positions and to what degree of participation? Is it a common belief that holding the principal trumpet position in a symphony orchestra is the ultimate goal of all trumpet players? Marie Speziale performed with the Cincinnati Symphony Orchestra for thirty-two years as the Associate Principal. She was offered the Principal position but turned it down because she felt it would limit her opportunities to do other types of performing. Looking back over her career, Joyce Johnson-Hamilton stated that "having the opportunity to pursue a variety of musical paths" was always important to her. Susan Slaughter shared that in her thirty-seven years (to date) as principal trumpet with the St. Louis Symphony, she did few "outside jobs" and did not do very much teaching. Do the demands placed on a principal trumpet player in an orchestra limit other possible opportunities?

A common thread running through the careers of most of the women covered in this study is that, as female trumpet players, they were perceived as novelties. Reviews of recitals and concerts often focused first on appearance, and then on the quality of the performance. Many women used the novelty aspect to draw an audience and further their professional careers. Carol Dawn Reinhart won a beauty contest in college and that, along with her proficiency on trumpet, led to appearances on the Tonight Show and other popular television shows. Reinhart was able to establish a career as a soloist but most of her performances were in countries other than the United States. She said that in order to be taken seriously, she had to perform, not as good as, but better than her male colleagues.

Joyce Johnson-Hamilton said, "I have always known that my opportunities were likely to be limited by the fact that I was a woman." She also indicated that she definitely had some advantages because she was a woman. She, too, took advantage of the novelty aspect of women as trumpeters when she traveled to Seoul, Korea eleven times to perform with the Seoul Philharmonic to sold-out audiences. She said she was perceived as being exotic because she was a female conductor, trumpet soloist, and arranger. ${ }^{5}$ This perception is reminiscent of how other multi-faceted performers such as Georgie Dean Spaulding and "Petite Bertha" Noss were received. Apparently, the cultural perception of female trumpet players as novelties was not limited to the United States.

Another common thread among these performers is their innate desire to play trumpet, and their refusal to give it up. They made a continuous effort to move forward, past the doors that were closed to them, and as necessary, created alternative performance opportunities. Edna White experienced stress in her first marriage when her husband wanted her to give up the trumpet. She separated from her second husband because her husband's performance opportunities were in Europe while hers were in the United States. Martha Awkerman's anecdote about choosing her trumpet over a man connoted her commitment to play the trumpet. Marie Speziale said, "The trumpet was the center of my universe. I was simply going to play trumpet. Period!" Barbara Butler advises all of her students to "never give up." She stated, "The great

\footnotetext{
${ }^{5}$ Joyce Johnson-Hamilton, interview with author, 29 January 2009.
} 
players don't quit. The great teachers don't quit. You just don't quit."6 Her career exemplifies that philosophy.

Female trumpet players have gained ground in the military bands. Having performed in their own, segregated ensembles during World War II, they are now integrated into many of the military bands. In 2000, Liesl Whitaker won the lead trumpet position with the United States Army Blues Band. The first female instrumentalist (with the exception of some pianists) to play in any of the Washington, D.C. special military jazz bands, she won one of the most important positions in the band. ${ }^{7}$ Another trumpeter to find success in an army band is Virginia Turner who currently serves as co-principal trumpet in the United States Army Field Band. ${ }^{8}$ Nancy Taylor was the first female trumpeter in the President's Own Unites States Marine Band. ${ }^{9}$ Additional study should be done to document the experiences and achievements of these women, as well as other female brass players, in this traditionally male environment.

In the early $20^{\text {th }}$ century, women musicians collaborated together to form their own bands and orchestras in order to be able to perform. The same goal was behind the creation of the First International Women's Brass Conference held in 1993. Many attendees believed the conference fostered a more widespread awareness of women as brass performers. Several all-female groups were created resulting from the networking done during the conference including Monarch Brass, Velvet Brass, and others. Many of the women who served on the Pioneer Committee of the IWBC (including Ramona Galey, Susan Fleet, Linda Dempf, Lisa Blackmore, Eloise Jenkins, as well as myself) have published articles, interviews, and research projects, adding to the existing body of scholarly research on women in music. Further study can be done to determine the long-term effects of that first conference and the five that have followed it.

\footnotetext{
${ }^{6}$ Barbara Butler, interview with author, 3 March 2009.

7 "Whitaker to US Army Blues," International Trumpet Guild Website, http://www.trumpetguild.org/news/news00/whitaker.htm (accessed 16 April 2009).

8 "Concert Band Biographies," The United States Army Field Band, http://www.army.mil/fieldband/pages/rosters/bios/cb_bios.html, (accessed 16 April 2009).

9 "Department of Music: Nancy Taylor," The University of Texas at El Paso, http://faculty.utep.edu/Default.aspx?alias=faculty.utep.edu/netaylor, (accessed 19 April 2009).
} 
Appendix A - Female Trumpeters in Symphony Orchestras ${ }^{1}$

\begin{tabular}{|c|c|c|c|c|}
\hline Artist & Orchestra & Position & Years & Source \\
\hline Adorgan, Irene & Flint Symphony & Section & $1946-47$ & 1 \\
\hline Baccarro, Karen & Monterey Symphony & & & \\
\hline Baccarro, Karen & Napa Valley Symphony & Principal & & 5 \\
\hline Baccarro, Karen & Women's Philharmonic & Principal & & 5 \\
\hline Beard, Roselyn & Altoona Symphony & $\begin{array}{l}\text { Section (listed } \\
\text { third of four) }\end{array}$ & $1947-48$ & 1 \\
\hline Black, Bibi & Philadelphia Orchestra & Second & $1988-89$ & \\
\hline Butler, Barbara & Grant Park Symphony & $\begin{array}{l}\text { Third } \\
\text { Principal }\end{array}$ & $\begin{array}{l}1975 \\
1976-78\end{array}$ & 3 \\
\hline Butler, Barbara & St. Louis Symphony Orchestra & $\begin{array}{l}\text { Acting Assistant } \\
\text { Principal }\end{array}$ & & 2 \\
\hline Butler, Barbara & Vancouver Symphony & Co-Principal & & 2 \\
\hline Carpenter, Lorraine & Oakland Symphony & & & 5 \\
\hline Carpenter, Lorraine & San Jose Symphony & & & 5 \\
\hline Carpenter, Lorraine & Women's Philharmonic & & $?-1992$ & 5 \\
\hline Carroll, Ruth & Enid Symphony Orchestra & Section & 1947 & 1 \\
\hline Cernohalvek, Leta & Billings Symphony & $\begin{array}{l}\text { Section (listed } \\
\text { third of three) }\end{array}$ & 1955 & 1 \\
\hline Comstra, Susan & Eastman Chamber Orchestra & Second & $\begin{array}{l}\text { 1970, } 1971 \\
\text { Summers }\end{array}$ & 3 \\
\hline Darn, Elaine & Duluth Symphony Orchestra & Section & $1945-46$ & 1 \\
\hline Davis, Joyce & Cape Town Symphony Orchestra & Principal & & 6 \\
\hline Davis, Joyce & $\begin{array}{l}\text { Orquesta Sinfonica del Estado de } \\
\text { Mexico }\end{array}$ & Principal & & 6 \\
\hline Davis, Joyce & $\begin{array}{l}\text { Orquesta Filharmonica de la } \\
\text { UNAM }\end{array}$ & Principal & & 6 \\
\hline Davis, Joyce & Cincinnati Symphony & Section & & 6 \\
\hline Davis, Joyce & Charleston (SC) Symphony & Section & & 6 \\
\hline Davis, Joyce & Savannah Symphony & Section & & 6 \\
\hline Duncan, Danice & Louisville Orchestra & Fourth & $1983-84$ & 3 \\
\hline Durkee, Ruth & Flint Symphony & Section & $1946-47$ & 1 \\
\hline Eberhart, Lauren & San Antonio Symphony & Second & $1996-$ & 3 \\
\hline Erickson, Lynn & St. Paul Chamber Orchestra & Second & $1990-$ & 6 \\
\hline Fleet, Susan & $\begin{array}{l}\text { Artists International Opera } \\
\text { Orchestra }\end{array}$ & Principal & & 5 \\
\hline Fleet, Susan & Opera New England & Principal & & 5 \\
\hline Fleet, Susan & Providence Chamber Orchestra & Principal & & 5 \\
\hline Fleet, Susan & $\begin{array}{l}\text { Rhode Island Philharmonic, Opera } \\
\text { Orchestra, and Civic Chorale } \\
\text { Orchestra }\end{array}$ & & & 5 \\
\hline Galey, Ramona & Boise Philharmonic & Principal & $1989-90$ & 5 \\
\hline Galey, Ramona & Sarasota Opera Festival & & & 5 \\
\hline
\end{tabular}

${ }^{1}$ This is not a definitive list but is a compilation from sources available to the author at the time of the writing of this document. 


\begin{tabular}{|c|c|c|c|c|}
\hline Artist & Orchestra & Position & Years & Source \\
\hline Galey, Ramona & Women's Philharmonic & second & & \\
\hline Galey, Ramona & Spoleta Music Festival, & & & 5 \\
\hline Grima, Patricia & Eugene Opera Orchestra & Principal & & 5 \\
\hline Hage, Dawn & Edmonton Symphony Orchestra & & & 5 \\
\hline Howlett, Mrs. J. F. & Billings Symphony & $\begin{array}{l}\text { Section (listed } \\
\text { second of three) }\end{array}$ & 1955 & 1 \\
\hline Hutchins, Gail & Baltimore Symphony & Fourth & $\begin{array}{l}1966-\text { ca. } \\
2004\end{array}$ & 3 \\
\hline Jay, Mary & Hamilton Philharmonic Orchestra & & & 5 \\
\hline Johnson, Madelin & Tri-City Civic Orchestra & Second & 17 Mar 1929 & 3 \\
\hline $\begin{array}{l}\text { Johnson-Hamilton, } \\
\text { Joyce }\end{array}$ & Aspen Festival Orchestra & & $\begin{array}{l}(1959-65 \\
\text { summers })\end{array}$ & 2 \\
\hline $\begin{array}{l}\text { Johnson-Hamilton, } \\
\text { Joyce }\end{array}$ & Cabrilio Festival Orchestra & Principal & (summers) & 2 \\
\hline $\begin{array}{l}\text { Johnson-Hamilton, } \\
\text { Joyce }\end{array}$ & Oakland Symphony & Principal & $1971-76$ & 2 \\
\hline $\begin{array}{l}\text { Johnson-Hamilton, } \\
\text { Joyce }\end{array}$ & Portland Symphony & Principal & $1965-69$ & 2 \\
\hline $\begin{array}{l}\text { Johnson-Hamilton, } \\
\text { Joyce }\end{array}$ & San Jose Symphony & Principal & 1976-80 & 2 \\
\hline $\begin{array}{l}\text { Johnson-Hamilton, } \\
\text { Joyce }\end{array}$ & San Francisco Symphony & $\begin{array}{l}\text { Assistant } \\
\text { Principal }\end{array}$ & 1968 & 2 \\
\hline Koehler, Elisa C. & Dayton Philharmonic Orchestra & & & 5 \\
\hline Kuhns, Sally Nelson & Oregon Symphony Orchestra & $\begin{array}{l}\text { Assistant } \\
\text { Principal/Third }\end{array}$ & $1980-2006 \mathrm{~s}$ & 5,6 \\
\hline Leach, Cathy & Knoxville Symphony Orchestra & Principal & & 2 \\
\hline Lundgren, Helen & $\begin{array}{l}\text { Southern Symphony Orchestra } \\
\text { (Columbia, SC) }\end{array}$ & Section & $1940-1951$ & 3 \\
\hline Lundgren, Helen & $\begin{array}{l}\text { Tri-City Symphony Orchestra } \\
\text { (Davenport, IA) }\end{array}$ & $\begin{array}{l}\text { Fourth } \\
\text { First } \\
\text { Second } \\
\text { First }\end{array}$ & $\begin{array}{l}\text { 16 Mar } 1941 \\
\text { 07 Dec } 1941 \\
\text { 19 Apr } 1942 \\
\text { 01 Dec } 1942\end{array}$ & 3 \\
\hline Magee, Ruth & Louisville Philharmonic Society & Second & $1944-45$ & 3 \\
\hline McCann, Shirly & Kearney Symphony Orchestra & Section & 1948 & 1 \\
\hline Meurer, Emma & Terre Haute Symphony & Cornet & 1943 & 1 \\
\hline Milverstedt, Dorothy & Tri-City Symphony Orchestra & $\begin{array}{l}\text { Third } \\
\text { Fourth } \\
\text { Third }\end{array}$ & $\begin{array}{l}\text { 14 Mar } 1937 \\
\text { 03 Apr } 1938 \\
\text { 26 Feb } 1939\end{array}$ & 3 \\
\hline Murtagh, Catherine & Women's Philharmonic & & & 5 \\
\hline Ostbrander, Ruth & $\begin{array}{l}\text { Tri-City Symphony Orchestra } \\
\text { (Davenport, IA) }\end{array}$ & $\begin{array}{l}\text { Section (listed } \\
\text { fourth) }\end{array}$ & $1945-46$ & 1 \\
\hline Peck, Jeanne E. & Tulsa Philharmonic & $\begin{array}{l}\text { Section (listed } \\
\text { third of four) }\end{array}$ & $1953-54$ & 1 \\
\hline Pinkney, Alice Aiken & Symphonette (New York) & & & 5 \\
\hline Rollinson, Barbara & $\begin{array}{l}\text { New London Civic Orchestra } \\
\text { (CT?) }\end{array}$ & Section & 1948 & 1 \\
\hline Saxton, Judith & Hong Kong Philharmonic & Principal & & 5 \\
\hline Saxton, Judith & Wichita Symphony Orchestra & Principal & 1999- & \\
\hline
\end{tabular}




\begin{tabular}{|c|c|c|c|c|}
\hline Artist & Orchestra & Position & Years & Source \\
\hline Sitho, Brenda & Thunder Bay Symphony Orchestra & & & 5 \\
\hline Slaughter, Susan & St. Louis Symphony Orchestra & $\begin{array}{l}\text { Fourth/Section } \\
\text { Principal }\end{array}$ & $\begin{array}{l}\text { 1969-73 } \\
\text { 1973-present }\end{array}$ & 2 \\
\hline Slaughter, Susan & Toledo Symphony & Principal & $1967-69$ & 2 \\
\hline Smith, Leona May & Brooklyn Symphony & Principal & & 5 \\
\hline Smith, Leona May & Metropolitan Opera & Extra & $1953-1973$ & 4 \\
\hline Smith, Leona May & Radio City Music Hall Orchestra & Principal & $1943-45$ & 4 \\
\hline Sorenson, Evelyn & Cedar Rapids Symphony Orchestra & $\begin{array}{l}\text { Section (listed } \\
\text { third) }\end{array}$ & $1946-47$ & 1 \\
\hline Speziale, Marie & Cincinnati Symphony Orchestra & $\begin{array}{l}\text { Associate } \\
\text { Principal } \\
\text { Trumpet }\end{array}$ & 1964-1996 & 2 \\
\hline Squire, Mary & $\begin{array}{l}\text { Cleveland Ballet and Opera } \\
\text { Orchestra }\end{array}$ & & & \\
\hline Tinker, Carol & Louisville Philharmonic Society & Principal & $1945-47$ & 3 \\
\hline $\begin{array}{l}\text { Warner, Carol } \\
\text { (a.k.a. Carol Carroll, } \\
\text { Carol Jones, and } \\
\text { Carol De Leon) }\end{array}$ & San Antonio Symphony & Second & 1973- c 1997 & 3 \\
\hline Weber, Mary & New Orleans Symphony & Principal & $1989-90$ & 5 \\
\hline Whitney-Ault, Susan & Binghamton Symphony & & & 5 \\
\hline Whitney-Ault, Susan & Florida Symphony Orchestra & & & 5 \\
\hline Whitney-Ault, Susan & Springfield Symphony & Co-Principal & & 5 \\
\hline
\end{tabular}

Sources:

1. Eloise Jenkins, collection of orchestral rosters.

2. "First International Women's Brass Conference Program, May 28 - June 1, 1993." held at Washington University, St. Louis, Missouri.

3. Norman Schweikert, letter to author, 10 January 2009.

4. "Biographies of the 1993 Honored Pioneers," Newsletter of the International Women's Brass

Conference 1, no. 3 (August 1993): 4.

5. "Women Brass Musicians: Past and Present, Professionals in Performance and University Education,"

St. Louis: International Women's Brass Conference, 1993.

6. Various university and personal biographical websites. 


\title{
Appendix B - West Virginia University Internal Review Board Documentation
}

\author{
IRB Protocol Exemption Notice
}

To: Thompson, Virginia

From: WVU Office of Research Compliance

Date: Monday, December 22, 2008

Subject: No action required

Tracking \#: H-21405

Title: Women as Professional Trumpet Players in the United States c1875 to 1993

Expedited - IRB Protocol - Exemption

The above-referenced study was reviewed by the Institutional Review Board and was granted exemption on 12/22/2008 in accordance with 45 CFR 46.101(2).

While no action is required on your part, the IRB made the following findings:

Once you begin your human subject research the following regulations apply:

The following documents have been approved and validated for use in this study and are available in the BRAAN system:

This research study was granted an exemption in accordance with Research that involves educational tests, survey procedures, interview procedures or observation of public behavior [45 CFR 46.101(2)]. If you have questions please refer to the IRB website.

Cover Letter

Verbal Introduction Script

Thank you.

Board Designee: White, Barbara

Letter Sent By: White, Barbara, 12/22/2008 3:03 PM

Once you begin your human subject research the following regulations apply:

1. Unanticipated or serious adverse events/side effects encountered in this research study must be reported to the IRB within five (5) days.

2. Any modifications the study protocol or informed consent form must be reviewed and approved by the IRB prior to implementation.

3. You may not use a modified informed consent form until it has been approved and validated by the IRB. 


\section{Cover Letter}

$<$ date $>$

Dear $<$ recipient $>$,

This letter is a request for you to take part in a research project concerning the history of professional female trumpet players in the United States. This project is being conducted by Robyn Card, a doctoral graduate candidate at West Virginia University; with the supervision of Dr. Virginia Thompson, Professor of Horn in the Music Division of the College of Creative Arts. The research is being conducted in partial fulfillment of the requirements for a DMA in trumpet performance.

The purpose of the project is to compile information from print sources (books, journals, etc) in order to document the history of women as professional classical trumpet players, and to expand on that information by including interviews with 3-6 players who are well-respected in the field trumpet performance today. The goal is not to "prove" any particular point, but to document these women's lives and careers and perhaps gain some insights from them regarding their experiences building successful careers in a historically male-dominated profession. My intent is to create a historical document that avoids, as much as possible, arguments about gender equality. My intent is to document what has occurred over the last 125 years as women have become more prevalent in the trumpet-playing world and provide a resource for future students, researchers, and trumpet-enthusiasts to learn about these artists.

This research has been reviewed and acknowledged by the Institutional Review Board at West Virginia University.

I would like to interview you as part of this project. If you agree to participate, I will record (digital or tape) the interview and create a transcription of this recording. Your name will be attached to the interview in both formats. The interviews will be edited for length and readability, but not for content. You will be able to review the transcript before the project is finalized. Neither the recording, nor the transcription will be used for any other purpose without your express written permission. The recording will be kept for five (5) years following approval of the thesis document, whereupon, it will be destroyed via a shredder.

The length of the interview will be approximately one hour scheduled at your convenience and will be done via telephone. Your participation will be voluntary and you may withdraw your consent at any time. You will not need to answer any question that makes you uncomfortable and may request the recording to be discontinued at any time. I may also stop recording the interview at any time.

I hope that you will participate in this project. Please contact me (757-338-1363/joscard@gmail.com) to let me know whether or not you would like to be a part of this study or if you have any questions or concerns.

Thank you for giving my request your consideration.

Robyn Card

112 Mallard Drive

Suffolk, VA 23434

cc. Dr. Virginia Thompson

226-A Creative Arts Center

West Virginia University

PO Box 6111

Morgantown, WV 26506-6111

Virginia.Thompson@mail.wvu.edu

(304) 293-4842 x3165 


\section{Verbal Introduction Script}

Hello,

I want to thank you for taking part in my research project.

The purpose of my project is to document what has occurred over the last 125 years as women have become more prevalent in the trumpet-playing world and to provide a resource for future students, researchers and trumpet-enthusiasts to learn about you and other artists. My goal is not to "prove" any particular point, but to record your experiences as you have built a successful career as a trumpet player.

I would like to remind you that this interview is being recorded. You need not answer any question that may make you feel uncomfortable, and you can request the recording be discontinued at any time. I may also discontinue the recording as well. I will send you a transcript of the interview for your review.

Do you have any questions before we begin? 


\section{Appendix C - Interviews with Select Female Trumpet Players}

\section{Barbara Butler}

Interviewed March 3, 2009

Where were you born and raised?

I was born in Waterloo, Iowa and was raised in Cedar Falls, Iowa.

Was your family musical?

Not professionally. My mother sang a little, and my father had played bugle as a young boy. Neither was particularly musical. I have two sisters and both of them did play instruments.

Was either of them a brass player?

No. Flute and oboe.

Why did you choose to play the trumpet?

I started on piano and I was just awful. My mother says I practiced all the time, but cried as much as I practiced. I could hear the music in my head but just couldn't get it out. I had a very lovely piano teacher who was a neighbor. In third or fourth grade they took me down to the local music store. I don't actually remember if they demonstrated instruments, but at that point I picked the cornet. Apparently, I did have a natural affinity for it; at least it was certainly natural compared to my affinity for piano. I picked it up rather quickly, so it was rewarding.

When you first started to play the trumpet, what kind of opportunities did you have to perform? I went to a school system that was known for its music and indeed in the state of Iowa, band music is quite a big deal. I began taking lessons in fourth grade from the man at the music store. I don't remember his name but he looked a little like Al Hirt. He was very calm, perhaps slightly bored during the lessons. Then, I joined the band right away in the fourth or fifth grade and I started taking lessons with the band directors, which was what people did back then. I didn't have a real serious trumpet teacher until I was in seventh grade.

Do you remember the names of your band directors?

Mr. Pancook and Mr. Manley were two of the band directors I had when I was young. I had a band director named Hugh Eicke when I was in high school, and Tony Lund was my orchestra teacher. I had a lot of opportunities. I joined the union at age fourteen. As a little kid I played with the American Legion Band all summer long, and got paid for it, playing solos like "Carnival of Venice." There were a lot of solo opportunities around me in Iowa and in the Midwest. You could audition for this or that solo opportunity, and if you won, you got to play a solo with that orchestra. I did a lot of those, and I won most of them. I think I just took those for granted. Now that I am a mother of a musician, I realize that the business can be very competitive, crowded, or perhaps lacking those opportunities. I was very lucky.

When was this?

It was in the 1960s. 
Who were your greatest musical influences during this time?

Though all of those band directors were kind people and champions for me, my major influence was the teacher I started with in seventh grade. His name was Dr. David Kennedy. He was one of the professors at the University of Northern Iowa, which was located in the town I grew up in, Cedar Falls. Interestingly enough, he was the horn professor. There was a trumpet professor as well. His name is Keith Johnson and he is currently teaching at North Texas. He is a very nice man, but I was drawn to the horn professor. He was a good fit for me in a lot of ways. He took me to national competitions and to lessons with principal chair orchestral players from the Minnesota Symphony. He inspired me to another level. At that age I was interested in a lot of things: writing, journalism, track, dance, etc. Trumpet, while important to me, was just one of my interests, and he could see that I might get bored. He also saw that I had a competitive streak. So, he kept challenging me with competitions, which I very much wanted to win. At the same time, instead of giving me a lot of boring fundamentals (which, to be honest, I needed), he gave me solos coming out of the Paris Conservatory. So, I learned how to triple tongue by practicing solos that had triple tonguing in them, rather than playing etudes where you would learn to triple tongue the way most kids would learn. At the same time, my band directors used the Arban book. If you practiced six pages, you could seat ahead of the guy who practiced four pages, so I would practice forty pages a night. That was good for me, as I needed those fundamentals. Then, when I would go to my lessons, where I would play all of the difficult French trumpet solos. At home, for fun, I would play Harry James, Al Hirt, Tijuana Brass, and pop tunes.

There's a very funny story: when I was in sixth grade, my parents moved into a house that had a bomb shelter built into the basement. The Cuban Missile Crisis was over by then, so my parents didn't really use that soundproof room for anything, but they asked me to practice there. It wasn't until a few years later that I graduated to being able to play upstairs where everyone could hear me, and I knew I'd made it!!

Were your parents pretty supportive of your efforts?

One hundred percent supportive. Really, really great. They are both still living, and I can't imagine any parents who could be more supportive. They went to everything I played, heard every note, every weekend, every summer, every month, every year. They still do. They are wonderful.

So, when did you realize that music was going to be more than a hobby, that it was going to be your life's calling?

There were two "aha" moments. One was when I went to Interlochen in the summer. I went for two summers, junior and senior year of high school. That was the first time that I had been exposed nationally, and actually even internationally (there were a lot of international players those summers) to other kids who were good and very, very serious about their music. That is an opportunity to check out your own motivation, interest, desire, talent and dreams, when you bump into others like that. So, at that point, I did discover that I loved it, and that it meant a lot to me. I could tell at that point that it was really great to play, and it was really greater if you were good at it. I still had a lot of catching up to do in my playing because I'd sort of skipped over a lot of fundamentals to play all the cool solos. For instance, my first audition the first summer I went to Interlochen, first they asked for a solo. I played Jolivet's Concertino, a very tough piece 
for somebody that age. I did it well and they were very excited. Then they asked me to play, I think it was Tchaikovsky's Fourth Symphony, an orchestral excerpt that I didn't know at all. I absolutely butchered it. I butchered the transposition and the rhythms. I didn't really know it. I just think I sort of made it up. I don't know what I did. By the time I finished, all of the judges were holding their sides, laughing. The situation at Interlochen back then and now are maybe a little bit different, but I think I seated seventeenth chair, and I had never been anything but first chair. I was just disgusted. But they had this challenge system, and the challenge excerpt was the Dvorak New World Symphony. I can still remember the passage. I could play it right now, in the dark, with my eyes closed, on the phone. E transposition. I practiced that like a maniac, so when we got to that first audition, I challenged player number sixteen, and I beat him so we switched. Then I challenged player number fifteen, and I challenged fourteen, and thirteen, and all the way until I got to the first chair player. At first nobody was paying much attention at the top of the section, and then they were swiveled around, staring at me. I got up to the first chair, and I couldn't beat him. I tied him, but I couldn't beat him. That whole summer, the best I could do was tie him. I couldn't beat him. It was Al Vizzutti. The next summer when I went there, I was first chair in the top orchestra, and first chair in the top band. I don't think you can do that anymore. And I was a concerto winner. I was actually playing way too much that summer, and even hurt my lip a bit. Those summers were fantastic for me to realize that I could just do music all day long, and that I wanted to, and that I liked being around people with whom I shared that interest and passion.

Nonetheless, I still hadn't made the ultimate commitment. My second "aha" moment was when it was time to go to college, I decided that playing the trumpet was kind of easy, so it was almost like cheating to major in it, and that I should go into something "more important." So, I majored in comparative literature, and went to a liberal arts college, St. Olaf's College. They had a great orchestra. I played first in the orchestra, and I played the Enesco Legend with them. We went on tour to Norway. I was playing constantly, but my major was comparative literature. My teacher was Ron Hasselman from the Minnesota Symphony. Towards the middle of that year he said, "What do you really want to do when you grow up?" and I said, "Oh, probably play in an orchestra, maybe teach." He said, "Well, what are you doing here? You've got to go to Chicago." So, I did transfer and the next year as a sophomore, I started at Northwestern University. That was my other "aha" moment.

What years were you at Interlochen?

'69 and ' 70.

Why did you choose to go to Northwestern?

Actually, as I've found out now from the other end of the tunnel, most people in high school don't have a clue where they should go. Even though they have parents, band directors, and teachers telling them things, those people often do not know the best place to be. They don't know what is currently the best. They don't know who is producing what students. They don't know who is winning what jobs. They really don't know. The parents will say, "Well, I went to the University of Something and that was good enough. Why does this cost more than this and why is this different from this?" People don't know. And I didn't either but I was lucky that my teacher, Ron Hasselman, said at that point, "Chicago is the place to be. That's where all of the great players are. The Chicago Symphony Brass is unbelievable. Herseth is great, and there is 
this new teacher at Northwestern, Vincent Cichowicz, who is really turning out some great students. You need to go there." So, that is the only place I auditioned.

What was Cichowicz like as a teacher?

Very calm. He was not lenient; he was specific. He was always very kind to me. I don't know if he was to everyone. He expected you to be your best every second. In other words, if you were not playing correctly, he would stop you after one note or four measures. He would really only let you play correctly. So, basically you ended up playing perfectly, correctly for the whole hour. It felt calm and easy, and you sounded good, and it was wonderful. It's funny that in my memory the lessons seemed slow. You didn't race through a lot of music. You did things deeply, correctly, right. However, I got through a lot of books, a lot of etudes, a lot of orchestra repertoire, and solos, and piccolo trumpet, so somehow we covered material. In my mind it was slow and careful.

Did you study with anyone else while you were there?

Yes, I was a member of the Chicago Civic Orchestra, the training orchestra of the Chicago Symphony. Back then, when you were in Civic, you got free weekly lessons with Bud Herseth. So, I had regular lessons with him as well. Of course, in the summers, I did Aspen, and the Pierre Monteux Festival, and Tanglewood. I did a lot of wonderful summer festivals where you studied with different people.

What was it like studying with Bud Herseth?

Very different from Cichowicz. Cichowicz would talk, and explain, and stop you to make sure that you were staying right. Herseth would never stop you. You would play through the whole entire thing, and struggle along, and get through it. Then, when you were finished, he would say a few absolutely, spot-on comments about what you needed to do versus what you were doing. Then he would demonstrate.

That must have been some experience, hearing that sound, being in the same room.

It's funny, you know, I heard him every week. I had heard him when I was in high school as well, even in junior high, various times either when they were on tour or on the radio. Hearing him every week was very special, but hearing him in the lesson was very different because sitting so close to him, it sounded exaggerated to me. I couldn't really believe that he actually played that way. I thought he was being a caricature to make his point. But he actually did play that way. He was not bland, ever.

Who were some of your peers when you were at Northwestern? Were there any other female trumpeters in school with you?

There were a few of us. Susan Enger comes to mind. She is a year younger than I am. She is playing, I think, in Memphis right now. Actually, one of my best friends was Gail Williams, the horn professor at Northwestern now, and for twenty years a member of the Chicago Symphony. She and I played in a brass quintet together all through college. There were not lots of women trumpet players around, especially older ones that I might look to as an example. I was always just about the only one everywhere I went. I got used to it, and it was very normal for me to have that. I didn't hate it or love it; it was just normal. 
Some of the women trumpet players who were around were not always the best examples, either. I remember that in my life I had seen older women players who had a chip on their shoulder, essentially saying, "If I'd been a man, I would be famous." While that might actually have been true, it made it unpleasant to be around them. I don't think that men or women love playing with people who have a big chip on their shoulder. Then, the other extreme would be somebody with very low self-esteem, just assuming that all of the guys are probably better. That was a bad example, too. To be honest, I didn't really have women role models. My role models were the men and my teachers of the Chicago Symphony.

What year did you graduate from Northwestern?

I got my bachelor's in '74. Did my master's in '75, though I didn't complete it because I got a job part way through. That year I won two positions. One was principal in Grant Park, which is a summer orchestra in Chicago. The other was co-principal trumpet with the Vancouver Symphony in Canada. The year I began taking auditions, there were five openings. I knew if I was going to win a job that year, and I was determined to win it, it would be one of those five places. One was the Chicago Symphony, that was the position Phil Smith won. One was Cincinnati, and Phil Collins won that. The other three were in Canada: Montreal, Toronto, and Vancouver. Maybe I'm forgetting, but those are the ones I remember. Those are the first ones I ever took, plus Grant Park, which I had won.

Can you talk about your audition experiences? Were you behind a screen?

It was pretty funny, some were and some weren't. I remember that when I played in Montreal, it got down to three of us. It got down to me, Jim Thompson - who won the position - and Don Hazard, who played principal in Honolulu. There was a screen in Montreal, but I found out years later that everyone knew who I was. It was like a faked screen, you know?

That was also a very good lesson for me because when I showed up for the Montreal audition, there were other players there from the Chicago area, who were more experienced players than I was, and I advanced to the finals and they did not. So I learned that anything was possible at an audition, you have your own package, and must not stress over what someone else's package is, just continue to work on your own. Like a baseball team, a better team might win the best four out of seven, but in one game anything goes. And that was important for me to realize, as I was such a young and inexperienced, though talented player. It opened up many possibilities for me, I felt unlimited.

It is very hard to lose an audition. The track record of our students from the eighteen years as Professor at the Eastman School of Music and the now ten years as Professor at Northwestern University is quite something. I am very proud of our students. They hold positions in the top orchestras, military bands, and colleges and universities in this country. We are very fortunate by the level of students we get to mentor, and are incredibly honored to work with them. But sometimes I have to watch them lose, and I remember how hard that is. It is hard to survive the disappointment and fear of failure. Of the three ingredients needed to make it - talent, work ethic, and will power-will power ends up being the most vital at the end. I have seen incredible talent fall by the wayside because they did not have the will power. 
Tell me a little about Grant Park. Was that your first position?

Yes it was. It was kind of an odd situation, to be honest. We had two conductors, Leonard Slatkin and David Zinman. Slatkin held the audition. I don't know how many auditioned. Maybe there were thirty, I don't remember, but it got down to two of us. I did win the position. In the meantime, two of the interior section players had wished to have a shot at playing principal, though they hadn't auditioned. Slatkin agreed to let them try, even though I had won the audition. It was a strange situation. I don't, to be honest, remember the details. But the first summer, I played second to them, which was still great. It was my first job. The orchestra was fantastic. Both of those conductors were excellent, and it helped me learn the business. We performed great repertoire. Neither of them won the position, so the next summer I was given the principal trumpet position that I had previously won. That was excellent training for me, and it taught me how to lead a section. It was just two or three rehearsals and go. We would produce several concerts a week, and you just have to learn music, and produce it right away, right away, right away. It was so good for me.

What type of practice routine did you do to maintain your skills?

I had to learn some new things, because I had been in "student land." I'd been a really good student, and I got a lot of opportunities as a student. As I said, I played with Solti. I'd been in Civic Orchestra. I'd played extra in the Chicago Symphony on their recordings with Abbado, and on tours to Carnegie Hall. I played extra with Lyric Opera. I went to the Mostly Mozart Festival with the Chicago brass section, and the Rug Concert Series in Minnesota. I had a lot of good opportunities, but I was sort of "guesting" with all these things, so suddenly, when I was the leader, I wanted to be Herseth. I didn't know how to do it. Nobody really knows until you try it. I did a lot of things wrong. I actually give a class, a required class that I have given since 1980all those years at Eastman and continuing now at Northwestern - called Orchestral Etiquette. It is a required course that teaches all these things that I wish I had learned before I had to figure it out in front of people.

So, what I had to learn about practicing was that you cannot have the student mentality of wondering if it's going to be a good day or not. As a professional, you can't have bad days, so it doesn't matter what it is. It's a day. It's not a good or a bad day; it is just a day. My attitude didn't quite catch up to my auditioning, so that I remember the first few concerts at Grant Park and rehearsals, thinking this doesn't feel good so I guess it's not a good day. Then it was very interesting because - at that point I lived very close to Grant Park, maybe fifteen minutes away, in downtown Chicago-I would warm up and think, "Oh, my lips aren't good. I guess it is not a good day," and I would have that fear, "Oh no, what am I going to do?" Then I would think, "Well, I've got to get in the car and go." So I'd get in the car, drive down to the park and the second I got down there and pulled out my horn, I could play. It took me a ridiculously long time before I realized the reason I could play down there was because I had to. My attitude towards my warming up had obviously been defensive rather than offensive. As soon as I switched it around and got really aggressive about getting it going, I don't think I've had a bad day since. And I mean never, not once since then. I don't mean that I have perfect lips. I do not have perfect lips. I'm just like everyone else. I might be overtired, or out of shape. I might have this or that. But, it's never a bad day. You just deal with it; you do what you need to do, and you get it going. Honestly, I've never had any insecurities since having that giant light bulb realization. 
I know you met your husband when you were in Chicago, and then you both ended up going to Eastman at the same time. Can you talk about how that came about?

Charlie Geyer is eight years older than I am, and he got into the Chicago Symphony when he was very young. He was really a star player. He was in the Chicago Symphony, fourth trumpet, when I first saw him and met him. When Cichowicz retired, Charlie Geyer moved from fourth up to second. As fourth trumpet in Chicago, he wasn't desperately needed at Ravinia in the summer season; so instead, he went over to play principal in Grant Park. When he moved up to second in Chicago, he had to quit his job with Grant Park, and that is when that position became open. At that point, I was playing extra with Chicago, doing some touring and a little bit of recording with them, so I worked with Charlie sometimes. He was exiting Grant Park as I auditioned for that position. It was '75, '76, I got the job there at Grant Park, then won the Vancouver position, and moved to Vancouver (Canada), but I continued to come back in the summers to play Grant Park.

During that time, we ended up getting together, and we were trying to find some way to have our lives be together. It's very difficult when you play instruments, not to mention the same instrument. The crunch came down around 1978. He left the Chicago Symphony because he wanted to play principal, so he went down to Houston to play principal. Phil Smith had already left to play principal in New York, and Charlie then left to go down to Houston to play principal. So now, I'm in Vancouver and Charlie is in Houston. We were communicating back and forth, trying to figure out some way to get our act together, and we actually ended up with three offers, in '79 or '80. One of the offers was for him to come to Vancouver to become fourth trumpet in Vancouver and personnel manager. He was keen to do this. Vancouver is a beautiful city, and it was a young, but very good, orchestra. I was a little worried that that would somehow be below his talent, or that it would be a situation where I was a leader and he was not so much. I wasn't sure that that was so healthy.

Another offer came in at the same time, from the music director in Houston at that time, [Sergiu] Comissiona. He was the music director of Houston, but he was a frequent guest in Vancouver. He loved Charlie as his principal trumpet in Houston, and he also loved my playing because he had heard me play principal in Vancouver. So he decided that he would love to have us in the same orchestra, which is what we wanted. He offered for me to become co-principal trumpet with Charlie in Houston. This sounded perfect except for the fact that there wasn't an opening, and he was going to fire someone to make it happen. We felt that this was bad karma and just not something you do to colleagues, so we declined that offer as well.

Then, out of the blue, there was a position at the Eastman School of Music. Neither one of us had been to the Eastman School of Music; we were Chicago people. We didn't know anything about the school. Apparently, they'd had a search on for a couple of years, and they had hoped to get Tom Stevens, but that didn't work out. So they had been interviewing and auditioning lots of people. We were odd for them because we were two, not one. And we were not going to be two sharing one, because we both had tenured positions in our orchestras. They brought us in to Eastman to give a masterclass and we were not very serious about it; but we said, "Sure, we will come." We gave a class, we taught individually, we performed together, and we did everything we could to help the students for the few days that we were there. Surprisingly, we ended up having a warm and fuzzy feeling about that school. The director of music there, Bob Freeman, a great person and great thinker, was also pretty good at trying to tempt us to come. As it turns out, 
that seemed the least flawed of the three offers, because we were both giving up our orchestras and together trying to build something new. In my case, I was more worried than Charlie was; he had had quite a long orchestral career already. Mine had been very short, and I wasn't so sure that I wanted to quit. But we were both sacrificing equally to try an exciting new opportunity, so we decided to try it. We started at Eastman in 1980.

You were there for twenty years?

Eighteen years. We left in 1998.

\section{What made you decide to go to Northwestern?}

We were doing lots of performing around the world, and quite a majority of it in Chicago, though we lived in New York. We had, from the middle 70s, started playing with a group in Chicago called Music of the Baroque. It was the largest choral organization in the United States at that time. Maybe it still is. They did B-minor Mass, Christmas Oratorio, all the big Handel pieces, and lots of trumpet features. We started playing with them in the 70s. They featured us a lot, both of us together and as soloists. We would come back once a month or so, fly back from New York and play with Music of the Baroque. We continued to do that, and we joined another Chicago group called Chicago Chamber Musicians, which is the premiere Chicago chamber group made up of a select group of strings, winds, and brass. We began to be featured and played with them a lot. All that was great, and then I had a baby. Though I had a baby, I kept trying to do all the same schedules and touring that I had always done, including traveling all over the world. We performed concert tours of Japan, Italy, and Spain, etc. But suddenly with the baby it became very challenging. I didn't have a baby to leave her with other people; I wanted to be with her all the time. I took her everywhere with me. We did a twenty-concert tour of Japan with a nursing two-year-old. We were the soloists. It was unbelievable. It was all good; I could do it, but it was seriously burning the candle at more than two ends.

All of a sudden, Cichowicz was going to retire, and Northwestern came courting the two of us. We felt like our situation at Eastman was excellent, again maybe bad karma to switch from something that was going so well. Our students had been winning so many positions. For instance, three of the four players in the Chicago Symphony are our students and all of them studied with us at Eastman. There were just so many great players. But we said, "Well, okay, maybe." We came to Chicago, auditioned, and it was good fit for us to be here. We still had all these connections, and we still had a majority of our concerts here. The thought of being able to just get a sitter for two hours instead of getting on a plane and having a nanny was appealing. So we decided to make the switch.

\section{And you have been there for ten years now?}

Yes.

Did you run into any difficulties with both of you being very good professional trumpet players? That had to bring up some interesting situations. How were you able to create a good balance? I do think it is challenging, and I do not necessarily recommend it. We did, however, make it work. Keep in mind that though we met in the 70s, and got married in 1978, we didn't live together until 1980 . We both had very separate careers and very separate lives. So even though I think it appeared to the world that we were together, we had completely separate careers for 
quite a while. We had both established our own personalities, and our own playing, and our own self-confidence, our own salaries, so that when we then blended our lives together, we found the benefits outweighed the tough choices. Two of the greatest benefits are these - one, if you have a great performance, or if you have a disappointing performance, your partner understands without a word being spoken; and two, it is impossible to coast or plateau, if you are surrounded by another person who is excellent, and who is working hard. We have not let our playing relax or drop down. We haven't really been able to. That has been very good for us, and ultimately, since this matters to us a lot, very good for our students.

Do you think gender has played a role in your professional development?

Of course. I can't say otherwise coming from the time period of my training. I cannot say that it was not a factor. Do I think it is still a factor? Yes. Do I think it is less? Yes. Do my young women students experience it? Yes. But they take so many things for granted that we didn't. Those of us who paved the way, paved it hard. I think that when you are a little girl, and if you are lucky and have a family structure around you, and musicians, teachers, and mentors like I did, then they just tell you that you are great. "You're great, honey. You've got great potential." And they mean it, and you believe it. Then when you are my age, you are doing it, you see that you are good at what you do, and it matters. The hardest time is college age, or, if you don't get a job right away, maybe freelancing. That can really be a tough time because it isn't as if you are ten years old and you've got a lot of potential. And it's not like you are my age, and you've got a big job and a salary, and you are doing it. It's like, "Are you going to make it?" I think that was a very trying time for all of us, men and women. It showed your mettle. It showed what your willpower was, and how hard you were willing to work. I don't think that it was about being male or female. I think that it was personal, about who you were. I think that women brass players back then had to work more, and I think the ones that made it did.

What techniques or activities have you used to help maintain your mental, spiritual, and physical health?

I'm not a moody person; I'm an even person. I do have a healthy, self-protective ability to kind of shut off bad memories, or disappointing times in my life, or times when I have not acted or thought to act in a way that later I realized that I wished had done. I don't beat myself up is what I am trying to say. Life is not always easy, and some people are dealt much harder choicesphysical, friendship, and family - really a lot of tough things. I've always been a very lucky person. My answer to everything was to just work harder. I have an excellent family: my child, my husband, my parents, and my sisters. I've been surrounded by classy and loving people who believe in work; people who grow up in Iowa don't whine. Don't whine. Just go do it.

\section{What are your non-musical passions?}

For years and years, we've had and raised Arabian horses. We started this in the 70s for just pleasure riding, and then for breeding, and then lots of showing, and then for fox hunting. It was a huge passion for a long, long time. We had a stable in our New York home. We have a stable in our Chicago home, a small one. Currently, all of our horses are deceased. We moved here with three when we moved from New York. We sold one and kept two, but they are both gone. We have an empty barn for now. We have animals. Currently we have three dogs, four cats, and two birds, and we have had bunnies, a goat, and lots of different things. I also love to read. That is my comfort activity. 
It's been obvious to me for a long time, that I resisted being called a teacher, because I grew up with that horrible thing that people say, "Those who can do, those who can't teach." I really thought that if you were a great player, that you would be playing. That is all I wanted to do, so I went right out of college and got my performing job. However, when we started at Eastman, we found that we could teach and do a lot of playing. It was only orchestral music for part of the year, but I now value the balance I get from my playing and my teaching. I went to play with St. Louis for that one season; that was lovely. I got to know Susan [Slaughter]; that was fantastic. I played a tour and a recording with the New York Phil. Charlie's done the same thing with various orchestras.

Right now our orchestra is the Grand Teton Music Festival in the summer. It is really a great allstar orchestra, made up of players from all the top orchestras. During the year it's mostly chamber, solo, and baroque music that I perform. For a long time, I would resist being called a teacher. "No, no, no, I'm a player. I'm an orchestra player. I just happen to be teaching here at Eastman." I gave that up a really long time ago, because I realized that I can teach, and that I care about it; that my students' successes mattered as much to me as my own. So I don't fight that anymore.

I remember that the Eastman Brass Quintet came to my school, James Madison University, in the mid 1980s. I think you were the first professional woman trumpet player that I had seen perform.

It seems like a long time ago that I was breaking those barriers, but I do very clearly remember so many comments. Sometimes they were goofy. People would come up, and they wouldn't know what to say. They'd say something like, "Do you wear lipstick when you play?" What does that have to do with anything? People just did not know what to say. I'd get huffy a little bit when I was younger. I can't tell you the number of interviews and comments I've had where they would ask me questions they would never ask a man. Again, I just realized that if I had a chip on my shoulder about it, then no one wants to be around that. So it was just easier if I dealt honestly with people staring at me, and wondering whether it was more challenging than for a man, or them thinking about my body, or my clothes, or whatever. There was one interview where the person asked me if it was hard for me to play. I said, "Not since I've been taking steroids." And then, he started to write that down. I said, "That was a joke!" If I hadn't caught him he would have written it down!

As a teacher, what is it that you want most for your students to take away from your studio? What is the biggest impression you want to make?

Never give up; work is always the answer. Great players are always students, always learning. We believe that it is better to be kind than to be right. We are very proud that our students are as known for being good citizens as they are for being fine players. I just think you never give up. The great players don't quit. The great teachers don't quit. You just don't quit.

You attended the First International Women's Brass Conference. What was your impression of that conference?

I wasn't so sure that I wanted to do that. I was used to being the only woman around, and to have a thing that excluded men felt as wrong as men excluding us. Instinctively it felt wrong to me. 
But Susan Slaughter was very big on me doing it. She said that they needed me there. There were all sorts of different people there. There were people who had made it. There were young people who didn't know if they were going to make it or not, and they were looking to us to be examples, and I thought, "I didn't have any of these. I had none of these women examples. I need to be an example." There were boys there as well and I thought, "They need to see us." I ended up being humbled and proud that I was there at that first one. Susan Slaughter was tireless and persuasive in believing in this project, and being able to pull this off. She is one amazing person. When I was participating in the conference, I could see that it meant a lot and that it was going to change the landscape, and it did.

How do you think the IWBC has changed the landscape for female brass players?

Those of us who had already made it had an increased support platform. Those young women who had not yet made it felt momentum and a support from their women colleagues. If anyone had felt alone in this business, they no longer felt that. And any men participating felt the groundswell of power. 


\section{Joyce Johnson-Hamilton}

Interviewed 29 January 2009

Where were you born and raised

I was born in Lincoln, Nebraska. I grew up in Ralston, a small town southwest of Omaha.

What was your family like?

There were four children. I was the third child. I have two older sisters and a younger brother who died in 2006 of Alzheimer's.

Was your family musical?

Yes and no. My sisters were both members of an outstanding a cappella choir in their Omaha high school. Neither of them continued with music after high school. My brother played the euphonium all through high school and college. He was very involved in barbershop singing throughout his adult life. My mother sang in the church choir for a few years when we were growing up.

Why did you choose to play the trumpet?

I had seen a trumpet up close for the first time on the occasion of a visit to a relative's home. I still visualize that silver trumpet lying there in the case, and being very impressed. When I had the opportunity to select an instrument, I knew right away that I wanted to play the trumpet. I'm sure it was just from that experience.

Had you heard the trumpet before?

I do not remember being attracted to the sound of the trumpet. Like many very young children, the sight of the instrument made more of an impression than the sound.

The Douglas County 4-H Band gave a concert at our school for the purpose of recruiting beginning players. I had not yet been fitted for glasses and with my very myopic vision I could not even tell where the trumpets were in the band! However, I was absolutely certain what instrument I wanted to play. I walked past the drums and the clarinets. The clarinets looked way too complicated with all of those keys. Then, the elegant elderly gentleman who was the band director said, "This young lady has a perfect trumpet lip." That's all I needed to know.

How old were you?

I was eight years old.

Were you in the school band program?

No, I joined the Douglas County 4-H band program. That was in the Omaha area. We rehearsed once a week, and went to many of the county fairs in eastern Nebraska. The highlight of our year was the trip to the state fair in Lincoln. We marched in parades and played concerts. 
Were there any other performing opportunities for you?

Not in community ensembles. I remember playing for eighth grade graduation.

Do you remember what you played?

Absolutely! I played the same thing that the solo cornet player in the 4-H Band played on every concert-“"Tramp, Tramp, Tramp." I had memorized it without ever having seen the music just by having heard it over and over.

What other solo playing did you get to do?

Our little suburban town of Ralston didn't have a high school until I was a sophomore. At that point we began to go to high school music contests. I did play solos then. Once in a while, I would play for something, some group that would want me to play. I probably would play my contest solo.

What year was that?

That would have been the early 1950's.

Do you remember hearing or seeing any female trumpet players performing?

There was another girl two years older than I was who's name was Vesta. She not only took up the trumpet in the fifth grade while I took it up in the third grade, but she took private lessons. I was always behind Vesta. That was the only girl I knew who played trumpet. It didn't seem odd at the time. Being two years apart in school we weren't really close friends, but we did travel to many, many rehearsals, fairs, and concerts together over the years.

Did you study privately?

I started private lessons when I was in the ninth grade.

Who was your teacher?

Fred Elias was a well-known trumpet teacher in Omaha. He had been a good friend of Herbert L. Clarke. They had studied with the same teacher. His daughter (Evelyn Elias) was a trumpet virtuoso. She had played in one of the big all-girl orchestras. Mr. Elias was very proud of his daughter. He had a photo of her with Herbert Clarke, which was taken in their living room. He definitely had a very close connection with the Herbert Clarke tradition and style of playing.

What kind of methods and music did you study while taking lessons?

Mr. Elias had written his own trumpet method book called "The Buzz System." He had me go through that book doing a lot of buzzing exercises along with amazing lip slurring exercises on the horn, and range studies. We did every single page of the Arban book in ninth, tenth, and eleventh grade. In all of my teaching, I don't think I've ever had a student who worked through the entire Arban book. I didn't realize what an accomplishment that was until I started teaching. I'm still waiting.

It is difficult to get students to work through all those keys.

They want to work on their orchestra or their jazz band music. 
Trumpet recordings were not so readily available when I was taking lessons. I did have two albums featuring Raphael Mendez. But there were no recordings of the pieces I was playing-no You Tube in those days...Y You Tube is such a great resource for students nowadays. My teacher knew all of the old cornet solos. I played "The Debutante" and "Willow Echoes" as well as all of the big cornet solos in the back of the Arban book. It is interesting that when (in my senior year of high school) I brought the Haydn Trumpet Concerto to a lesson my teacher scoffed at it and said it didn't look very difficult! At that point I knew I had turned a corner in my trumpetplaying career! There were no more cornet solos for me for many years. Mr. Elias felt that his students had completed his course of study when they finished the Arban book and he bid me farewell!

What do you think was one of the best things Fred Elias taught you?

Be prepared! He was older and a little gruff and very direct - three mistakes and you had to repeat the exercise for another week. I felt that I had better be able to do everything he asked of me. One of the things he had his students do was to be able to buzz a scale on the horn without valves. He had a system where he took you up to a double-high $\mathrm{C}$. He would have you play whole notes up to the "high note of the week" going up one-half step higher each week. It went on for as many weeks as it takes to get from a $\mathrm{G}$ on top of the staff to a double-high $\mathrm{C}$. When we were finished with that exercise he wrote, "OK" at the end of the exercise and we turned the page. Years later I found myself thinking, "I'll bet not all of his student could do that." It was all very matter-of-fact, and usually I got everything checked off each week and went on to the next set of exercises. It seemed very routine. Now I realize it is not that routine. Students vary wildly in their ability to master the technique of the trumpet in a given time period. Today they have a lot of activities competing for their time and attention.

I would agree that there are all kinds of things that drag their attention away from music. I never, ever, missed a lesson. My father and I had to drive thirty minutes into Omaha. For years we listened to the same thirty-minute radio program on the way to the lesson; then I would go in, have my thirty-minute lesson, and we would drive back home listening to another program. Except for three weeks in the summer, when I went to a music camp at the University of Nebraska, I don't remember ever missing a lesson. All that adds up to parental consistency - my parents were always there supporting my own mindset of "this is what I have to do."

Obviously your parents supported your trumpet playing.

Very definitely. Of course, I liked doing it, so they didn't have to ask me to practice. That was never a problem.

Can you talk about the three-week camp that you attended at the University of Nebraska? My original plan was to attend the University of Nebraska All-State Fine Arts Course in art. My sisters went to the university and told me about this summer camp. The only reason I didn't go for art was that I could never track down my art teacher to get a letter of recommendation, so I decided to settle for music. That was another very important turning point for me! I discovered that music was what I wanted to do for the rest of my life. The thing that I really came away with was that I wanted to be a conductor. I loved everything. I sang in the chorus, played in the band and jazz band, and took private lessons. It was just great. 
Did anyone think it was unusual that you played the trumpet?

I was never aware as a student that people thought it was unusual for a girl to play the trumpet. To be sure, most of the other trumpet players were boys. I did not have any girlfriends who played the trumpet, although one close friend played the French Horn. At All-State my friends were roommates in the dorms where we stayed. It might be someone in drama or art. As for being the only girl in the trumpet section-I was a terrible tomboy, so if I was doing something the boys were doing that was just fine. More outstanding women brass players majored in music at the University of Nebraska in the next generation after mine.

Did you go to college at the University of Nebraska?

Yes.

What year did you graduate?

I received my bachelor's degree in 1960. I stayed two more years to get a master's degree in performance and composition. I was at the University of Nebraska for a total of six years.

\section{Who was your trumpet instructor at Nebraska?}

I studied with three different teachers. The first one was Dean Killian who had a one-year appointment. He was subbing for a professor who was on sabbatical. He was an excellent trumpet teacher. I also played solo cornet in one of the university concert bands, which Mr.

Killian conducted that year. He was a big influence, and a very energetic guy who went on to be the head band director at Texas Tech in Lubbock, Texas. He was well known in Nebraska for his outstanding high school band in western Nebraska.

\section{What do you remember learning from Killian?}

He always said "Tone, Tonguing, and Technique!" He would repeat that over and over again. It was such a good way to remember the basic goals in any practice session. We worked on etudes and solo pieces for juries. It is hard to remember specific pieces.

For the next three years I studied with Jack Snyder, who was actually the French Horn teacher. We had two lessons each week - one was private and centered on technique, and the other lesson was with a few other students - at that session we worked with a piano accompanist. Jack Snyder provided the basis for my interest in trumpet solo repertoire. He was an excellent musician and conveyed a lot of interpretive ideas.

Dennis Schneider came to the University of Nebraska when I began my master's work. I studied with him for two years. He is retired now, but was a very fine player and an excellent teacher. We were almost colleagues because I played with him in the Lincoln Symphony. He was a big influence in my decision to pursue a career as an orchestral trumpeter. He had a lot to offer when it came to preparing for orchestral auditions. He had auditioned and had opportunities to play professionally, but it was difficult in those days to support a family with only an orchestra job. It was tough for him because it was his dream to play in a major symphony orchestra. He was a wonderful teacher who produced many very fine trumpet players in his years at the University of Nebraska. 
What things do you remember Schneider teaching you?

My technique was pretty much in place, so our work together was more about repertoire and stylistic issues. He introduced me to the orchestral excerpt literature, concerto repertoire, baroque trumpet repertoire, and many new volumes of etudes like the Charlier. He really supported my interest in conducting and went to bat for me when I applied for the position of musical director of the annual musical comedy production at the university. The fraternity that produced the show was not sure a woman could conduct the orchestra, but Prof. Schneider convinced them that I could do it. He, of course, helped me a lot in preparing recitals. We formed a brass quintet with the other brass faculty.

It sounds like he is the one who taught you orchestral playing.

Dennis Schneider really opened my eyes to the possibilities for developing into an orchestral player. However, it was the summers I spent at the Aspen Music Festival that really gave me the training and experience in orchestral playing that I needed to move on in the field. The first summer I went to Aspen was paid for by a Mu Phi Epsilon scholarship. It was another true turning point in my life. I returned to study trumpet and play in the Aspen Festival Orchestra for five more summers.

Do you remember any of the other players who were with you at Aspen?

James Levine was a teenager during my "Aspen years." He was a constant presence as a pianist, vocal accompanist and coach, and conducting student. I played under his direction quite a few times. Leonard Slatkin was a conducting student and later an Aspen Festival Orchestra assistant. I also played under his baton on a number of concerts. I played in a brass quintet with the horn player John Cerminaro when he was about 15 years old. We both played in the Festival Orchestra. The first summer I had a great roommate, Mildred Kemp-a terrific trombonist from Louisville. I studied with Robert Nagel and Bernie Adelstein from Cleveland, who were the two different teachers that were there during the six years I was there. It is hard to remember the names of the players who were there all those years that came and went.

\section{What kind of performing opportunities did you have when you were at the University of Nebraska?}

I played in the orchestra, the concert bands, and sang with the University Singers. One of my favorite groups was the full brass ensemble that met late Friday afternoons. It was always one of the best hours of the week. From my sophomore year on, I was principal trumpet in the university orchestra. I also played some violin, viola, and double bass while I was in college.

Did you have any performing opportunities outside of school?

There were three music sororities at Nebraska. We combined forces each year to do a big concert. The individual sororities did other musicales throughout the year as well.

I played in the Lincoln Symphony and a few church gigs. There wasn't that much outside playing to do. There was more music going on in Omaha, but that was the situation where the usual people had the work sewn up. I spent three years in Omaha teaching in the public schools, and nothing ever really opened up for me as far as freelance playing. 
Did you do any commercial playing?

I'm not sure what you mean by "commercial" playing. I never did any dance jobs, circuses or ice follies. They had a fine jazz band at the university, but I never played in it. I just did not get involved with the jazz end of things. I loved playing in a big jazz band at Aspen when they would pull one together. There I had time to play for eleven hours a day. That was great! I've done just enough to get a feeling for the genre. As an orchestral player it was fun to play Gershwin and symphonic pops arrangements, but I have no skills in jazz improvisation.

When you left college after earning your master's degree, was that when you taught for three years in the public schools?

Yes. I interviewed for a high school choral job but didn't get it. I did get a job in a really nice school district that's also a suburb of Omaha, so I was close to home. While I was in Omaha the conductor of the Omaha Symphony (Joseph Levine) created an assistant principal position so that I could play in the orchestra. I played quite a few Omaha Symphony concerts. He asked me to do the first trumpet part on the B-minor Mass. I think I was the only one in the history of Nebraska to play the B-minor mass on the piccolo trumpet or to play it at all.

I was soloist with the symphonic band and the orchestra at the university. I started going to Aspen while I was working on my master's; that was the thing I looked forward to in the summers. After three years of teaching I decided, much to my parent's horror, that I was quitting the teaching job and going to New York to make my career as a trumpet player.

What year was that?

It would have been 1965 .

So, you had a good job, and you were going to give it up to go to New York City to pursue a career in music?

That's right. I went to Aspen that summer. I was studying with Robert Nagel; I wanted to establish in people's minds that I would be in New York in the fall. There were a lot of New York freelancers at Aspen. That's when the conductor of the Portland Symphony, Jacques Singer, came for a visit to the Aspen Festival and, incidentally, was searching for a new first trumpet for his orchestra. Those were the days when a conductor could hire any player he liked.

We were sitting in a Sunday morning Aspen Festival Orchestra rehearsal. Maestro Singer had come to the rehearsal specifically to talk to Robert Nagel about who he would recommend. I saw a man with rather wild black hair talking to Robert Nagel who kept gesturing in my direction and finally he leaned over and said, "This gentleman is looking for a first trumpet player and would like to hear you play." So at the break, we went out behind the tent. I told him that I didn't have any audition materials with me. He asked me to just play something that I knew. I played the famous "Dance of the Ballerina" from Petroushka for him. I nailed it and he offered me the job.

I thought, “This can't be happening!" I said, “Don't you want to hear something else?” He didn't. That was it.

So, your next move was to Portland?

Yes. I never got to New York. I went right to Portland. 
And this was after you had already quit your teaching job?

Right, within two months I was going the other direction. I was in the right place at the right time.

And you were prepared.

Yes, I was right there, ready to go.

How long did you play with the Portland Symphony?

I played three seasons.

Did you play under the same conductor the whole time? Were there any guest conductors? Yes, Jacques Singer was the conductor all the time I was in Portland. I loved it. I loved playing. I loved getting paid to play, even though it was only $\$ 125$ a week to start with. We had two guest conductors: Igor Stravinsky and his assistant, Robert Craft, for a concert in 1966.

What was the section like?

There was a new second trumpet player who came to Portland the same year. The third trumpet shifted around a little bit. The second trumpet player was from Chicago and his wife played the cello. I don't know if it was a great section or not. We had to work hard to get things in tune and together. We got together for sectionals fairly often to work things out. I was just so happy to be playing. I knew I was living my teacher's dream. The very first concert I played we did the Shostakovich Eleventh Symphony, which has a lot of trumpet solos. Later in my first season we played the Mahler Fifth. That was very exciting. Stravinsky guest-conducted the orchestra in my second season. That was a great thrill.

What music did you perform for him?

The only thing Stravinsky conducted was the "Symphony of Winds." He was not very well and not up to conducting a lengthy piece by that time. We did the Pulcinella Suite on that program but Robert Craft conducted it. Stravinsky remained on stage for all of the rehearsals. Craft also conducted Beethoven's First Symphony, which was one of Stravinsky’s favorite pieces.

Did you teach while you were playing in the orchestra?

Over the three years, I built up a fairly large private teaching studio. I did some work in the Portland Public Schools after my first season ended, and one day a week the next year.

What was your next move after Portland?

I moved from the Portland Symphony to the San Francisco Symphony. In the spring of 1968, I received a notice of auditions for assistant principal trumpet in the San Francisco Symphony. I was not sure about being an assistant principal, but it seemed like a good idea to take advantage of the opportunity, so I decided to take the audition.

Can you describe the auditions?

Forty people showed up to audition in San Francisco. Nowadays that is a small number, but in those days that was a large number of applicants. They had just had a big strike. Along with higher wages, the orchestra members had won the right to hold auditions behind a screen with an 
orchestra committee hearing the preliminary auditions and the conductor joining them for the final auditions. San Francisco was one of the first orchestras to adopt this audition procedure. Gone were the days when a conductor could walk into a music festival setting and hire a player after hearing only one orchestral passage!

In the first audition I was one of four finalists. The conductor refused to vote for any of the four finalists, so there was no audition winner. A few weeks later, they announced auditions again and I flew to San Francisco again. This time about half as many people came. Two people made the finals and I was one of them. The other was Adele Sanchez who played in the National Symphony in Washington, D.C. Once again the conductor refused to vote for either of the finalists.

They finally announced the third audition. I wasn't terribly amused but I went down for it. There weren't as many people - no more than ten players showed up for the audition. I was the only one to make the finals. That was the day the conductor gave in and hired someone. The conductor was just apoplectic, because he had hired both a woman bassoonist and a woman trumpet player that day. While the elderly conductor's worst fears were coming true - a new day was dawning for women musicians! That got me to San Francisco. I had no illusions that the position was going to be permanent. Knowing that I had been hired against the will of the conductor kept me on the lookout for other opportunities. It really was too good to be true.

\section{Who was that conductor?}

Josef Krips. He was followed immediately by Seiji Ozawa.

You played with them for how long?

I played one season under contract. After I left the orchestra, I was first call extra and played quite often. The principal trumpet in San Francisco did not want an assistant. I think the conductor was going to use these assistant positions to bring new people into the orchestra. The principal was a good strong player. He didn't need or want any help.

What was that experience like for you?

I knew from the beginning that I did not like being an assistant first player. It wasn't that I didn't enjoy the people. I loved being in a great orchestra. That part was fine. They later changed the position to be an "associate" principal position. The "associate" player plays half of every concert. It became a position with more responsibility and musical outlet. Before one month had passed, I began looking for other opportunities - most important was a trip thirty miles south to check out the Stanford University doctoral program in early music. Playing only on concertos and $4^{\text {th }}$ trumpet parts was not my idea of playing in an orchestra. Many players like the idea of being able to afford a house, a car, and a family, and would happily play assistant first. I might even consider it now. For me - at that time - it wasn't the way I wanted to spend my life.

What did you do after leaving the orchestra?

As soon as I found out I wasn't going to be returning the next season to the San Francisco Symphony, I applied for the doctoral program at Stanford and was offered a graduate fellowship. 
That was in the early music program?

I began as a graduate student in baroque and renaissance performance practice. I played a lot of Baroque trumpet and a lot of cornetto, and continued playing frequently in the San Francisco Symphony and opera when they needed a fourth trumpet or back stage trumpet. So, I had a little extra money coming in, which was very nice.

\section{Tell me about your first experiences on the natural trumpet.}

My first natural trumpet was a coiled trumpet in D, similar to the one being held by eighteenth century trumpeter Gottried Reiche in that famous painting. Then I purchased one of the early Meinl and Lauber straight trumpets with the thumbhole. My earliest performances on the natural trumpet were pretty successful. It was very stressful and took enormous concentration to be accurate. I practiced the natural trumpet a lot-so much that my three-valve trumpet fingering technique began to get very rusty! It seemed actually easier to play on baroque trumpet than a piccolo. It was a total revelation to be able to play the baroque repertoire on a period instrument. I'd been playing baroque music on the piccolo and on the D trumpet since my graduate years at the University of Nebraska. By the time I arrived in the San Francisco area, Edward Tarr had made several recordings using the natural trumpet. I met Edward Tarr the summer before I moved to San Francisco. He was a great influence in my journey to become a performer on the natural trumpet. We had a friendship for quite a number of years. I haven't seen him for a long time. His parents lived in our area, so when he came to the San Francisco Bay Area he would schedule performances at Stanford Memorial Church. I did many performances on natural trumpet at Stanford. I really enjoyed playing the cornetto as well. I did not have my own cornetto, practically, until I gave it up back in the late 1970s. I started conducting and having children, so I had to give up something.

\section{Who was your instructor?}

There was no instructor in baroque trumpet. In the D.M.A. (Doctor of Musical Arts) program at Stanford, you studied original sources and other musicological sources to become familiar with the many different articulation styles along with the traditions and practices of ornamentation. We studied the art of realizing a continuo bass line for the keyboard. We learned how to read fifteenth and sixteenth century notation, and how to create modern editions. There were scholars working on trumpet ornamentation in the Fantini and Bendenelli volumes for early trumpet instruction. Hours and hours of practicing on the natural trumpet helped you develop an appreciation for the baroque style of playing. Many hours in the library opened up a world of new seventeenth and eighteenth century music to investigate. The Musical Rara editions made a lot of trumpet music available in modern editions. I just kept reading, practicing, and listening. Now, of course, there are really wonderful recordings and wonderful players to listen to. When I resumed my cornetto-playing career in 1999, there were so many more modern editions of seventeenth century music available as well as great recordings of the best cornetto players.

You have to use your musical sensitivity and realize that a lot of what you are playing in renaissance music is a vocal line. The style of attack is not as strong as a trumpet attack. It is an instrument that can sound like the human voice and approach great subtlety of expression through various styles of articulation. That seemed obvious to me from the beginning. But, finding the right instrument and mouthpiece is a great challenge. Very fine reproductions of 
sixteenth and seventeenth century cornetti are now available. When you play these instruments you are constantly studying the performance practice of the period.

Did you also study conducting at Stanford?

Yes, in fact I did change my emphasis to conducting. I realized that I really loved the full symphony orchestra; Stanford offered a D.M.A. program in symphonic conducting. As it turned out, I completed the course work and the required performances and research, but did not complete the final papers for the degree. I made the mistake of thinking it would be easier to finish the degree after our first child arrived. I was wrong about that!

When did you get married?

We were married in 1971. We have two sons, and are getting ready to be grandparents soon.

Was your husband supportive of your performing and conducting career?

Doug has been wonderful. The thing that drew us together was baroque music. He loved baroque music that featured brass instruments, and began to notice a young woman who was playing high trumpet in many of the concerts he attended. At the time, he was still registered as a graduate student in engineering geology at Stanford, so it was easy for him to find my phone number.

When I started doing conducting seriously, I had auditioned for two orchestras that were in the Bay area. While I was waiting to hear from these two orchestras as to who had been hired, I fantasized out loud about what a dilemma it would be if both orchestras invited me to be their conductor. His calm reply was, "Well, do they conflict?" Now there was support! And as it happened, I was hired by both orchestras, and they did not conflict.

\section{Is he a musician too?}

No, he is a geologist, but whenever I open the door to his office, I can always hear some Bach, Handel, Mozart, or Monteverdi. He listens to that sort of thing all the time.

\section{When were your children born?}

James was born in late May of 1972, and Colin was born in early June 1974. They were very cooperative in arriving at the best time in their mom's concert schedule.

How did you manage pregnancy and playing the trumpet?

Well, you just gradually lose your lung capacity. I did play a concert at Stanford with their brass ensemble with Gunther Schuller conducting when I was about eight and a half months pregnant. He was one mighty worried conductor. In fact, another trumpet player who leads the jazz band came and stood back stage, just in case I needed to slip over to Stanford Hospital and have a baby. I also played Beethoven's ninth symphony very late in my second pregnancy. My husband began to drive me to rehearsals during the last few weeks.

It sounds like he was really supportive of you.

He was very supportive. You have to choose a husband carefully. I won that lottery, that's for sure! 
What were the two orchestras that offered you positions as a conductor?

The Napa Valley Symphony and the Diablo Symphony in Walnut Creek. I conducted the Napa Valley Symphony for nine seasons, and I am in my thirtieth season with the Diablo Symphony.

With conducting two orchestras, did you give up trumpet playing for a while?

I gave up playing in orchestras and teaching. However, I did perform solos with my orchestras occasionally, in which case I would begin practicing about four or five weeks in advance of a program. Since 1990, after leaving the Napa Valley Symphony, I have enjoyed being able to devote a lot of time to natural trumpet and cornetto as well as resume my teaching at Stanford.

Your schedule must have been incredibly busy.

The period of time when I had three orchestras at once was unbelievably busy. Trying to teach private students at home with young children was very difficult - I finally gave up on that. Leaving home early for rehearsals, which were from fifty to ninety miles away, and arriving back home after midnight, was exhausting. The good thing is that not every day was that way. There was a ten-year period when my husband's mother required more and more care and attention. One of our sons was quite ill with several hospitalizations from the age of two and onehalf to fourteen. Life was rich and full and varied. When the boys grew up and left for college, it gave me more time to play trumpet, and then in 1999 I got back to cornetto, which has been another adventure.

In what other orchestras did you play trumpet?

I was principal trumpet in the Oakland Symphony under Harold Farberman for four seasons. That was from 1971 to 1976. Then I was principal trumpet in San Jose for four seasons until 1980. In Oakland I was appointed to be an assistant conductor. For several summers, I was principal trumpet of the Cabrillo Festival Orchestra with Carlos Chavez conducting. While I was in the San Jose Symphony I conducted youth concerts. I also conducted the Nutcracker Ballet for about almost twenty-five years.

What year was it when you gave up conducting the Napa Symphony and took up trumpet again? I left the Napa Valley Symphony in June 1989. Right about that time, there were beginning to be more and more early music performances using baroque orchestras in the San Francisco Bay Area. It was a great time to get back into playing the baroque (natural) trumpet. I've had a lot of really exciting experiences on the baroque trumpet since that time.

Did you find it to be difficult to come back after taking time off?

It was a matter of finding time to practice. If you have a purpose, you don't have trouble finding the time to practice. Once I made the decision to purchase a top quality baroque trumpet my interest in resuming trumpet playing and becoming more proficient as a baroque specialist was very keen.

Can you talk to me about your teaching? Do you have a lot of students?

I didn't begin teaching at home until after I left Napa and my children were grown. Eventually my studio grew to the point where I didn't have any free time whatsoever. Now I have only five or six trumpet students who come to my home; I usually have four to seven students per quarter at Stanford. 
How did you come to teach at Stanford?

I began teaching trumpet at Stanford in the late 70's while I was still registered as a graduate student. I taught there for about twelve years - until I went into conducting. I resumed the trumpet teaching position at Stanford in the early 90's. Around that same time, Stanford had a need for an orchestra assistant conductor, because they had discontinued their conducting D.M.A. program and therefore were left with no student assistants. Their conductor (Robert Black) had two other orchestras, one in New York and one in Finland! He was virtually never there, so I was the orchestra assistant for him for three or four years as well as the trumpet teacher.

If there is one main thing you want your students to take away from your studio, what would that be?

I encourage students to always warm up carefully, play scales, and work on technique regularly. I want students to learn how to use the tuner and the metronome as valuable aids to improving technique. I consider intonation, rhythmic accuracy, and speed to be the "quantifiable"- the things that can be measured - things that we can learn to control, improve, and fix. My theory is to always play at a tempo where you are completely comfortable and in control; then move the tempo up a couple of clicks at a time to a new level of comfort (and control). Pretty soon, you are playing it much faster, you are still comfortable, and you've been playing it perfectly all that time rather than thrashing away and making mistakes over and over again. That has been one of my strong teaching tools.

I love coaching people on repertoire and talking about interpretation. I show students that if they did exactly everything what is marked in the music (for instance, the Arutunian that is so heavily marked), if they follow all of those metronome, expression and dynamic markings, they will produce a musical sounding result. They will sound as if they know how to play expressively even if they do not feel it. Of course, it is wonderful when a student has a natural musical expressive ability, but it is a skill that can be taught. Even natural musical ability must be channeled in the right direction. In lessons I use a lot of metaphors and analogies.

It sounds like you have been very busy doing a lot of different things, trumpet playing, conducting, learning piano, teaching, and learning natural trumpet. Can you tell me about the early music groups that you perform in?

As a baroque trumpet player, I free lance in baroque orchestras which are usually put together for choral performances-Bach, Handel, Mozart, etc. In 1978 at the same ITG Conference in Wisconsin, I performed on a baroque trumpet recital with Edward Tarr. I've done several gigs with Catherine James who teaches at San Jose State. She is a fabulous baroque trumpet player. I did a piece with her on her recital last fall where she used cornetto instead of oboe on a Corbett piece. I've played several times with John Thiessen, who is a very fine player, and a number of times with Nicholas Eklund. Nicholas is a very exciting baroque trumpet player. It is wonderful when you are playing in a section where each member is an accomplished player. The sound is just fantastic. I have had the opportunity to do the high parts on the Bach B-minor Mass, the Magnificat, many cantatas, the Brandenburg $2^{\text {nd }}$, Handel's Messiah, as well as many solo pieces for trumpet, oboes, and strings. 
On cornetto I perform regularly with The Whole Noyse, which is a renaissance wind group in the located in the Bay Area. I also perform with WAVE (Women's Antique Vocal Ensemble) on both cornetto and baroque trumpet. Other cornetto gigs come up throughout the year. I have played the Monteverdi Vespers many times and most of the big Gabrieli polychoral works.

Who did you listen to? Who were your role models?

Very early in my trumpet studies I enjoyed listening to the solo albums of Raphael Mendez. During the years I was playing a lot of baroque music on the piccolo trumpet, Maurice Andre was a big influence. He was an amazing player, but once I began playing the same repertoire on the natural trumpet, his style of playing was no longer appropriate.

I love Nicholas Eklund's baroque (natural) trumpet playing. He has set a very high standard with the wonderful albums he put out with Naxos and with his recordings with John Eliot Gardner. My favorite recording of the Haydn Trumpet Concerto is by Helmut Wobisch. His cadenza is probably the most famous (and best) of the Haydn cadenzas. I always enjoy hearing any of Wynton Marsalis' recordings. He is just so musically and technically accomplished.

I have an ever-growing play list on iTunes of solos that students may be interested in hearing and/or playing. There are various artists represented in my files, but Phil Smith's playing stands out. He and I were both recital soloists in 1978 at the ITG conference. I think he had just gotten the New York job. He had been playing in Chicago. All of the music I performed, except for one piece, was from the seventeenth century and originally for cornetto. At that time I played it all on piccolo and D trumpets.

How do you balance the performance pressures of conducting and performing on trumpet? The pressure of conducting is in the preparation. I try to reserve the day of a rehearsal for concentrating on scores and don't let much else enter into my day. The day of a performance is one of making sure I have everything I need. The same goes for a trumpet or cornetto performance day. I make a list the night before of everything that needs to go...trumpet, mutes, music, stand, light. I try to allow a lot of time for commuting to eliminate as much stress as possible from the drive.

Some weeks are busier than others. It doesn't all happen at once. I don't always have a lot of playing pressures going on. Life just sort of unfolds. I've always been pretty busy and have enjoyed that.

What do you do to combat nervousness?

Being totally prepared is the best way to build confidence and combat nerves. However, you have to be very tough with yourself and practice in a way that gives you the best odds at playing a passage perfectly. That requires careful and exhaustive practice with a metronome, a tuner, and a recording device. I used to record my practice sessions. I still do that. I record and listen, record and listen. When I was in the Portland Symphony I would have a student listen to me play a difficult lick I had been working on. I would tell that student that if I missed anything, I would give him/her a free lesson. I never had to give a free lesson! 
One of the best things I have found for nervousness is to take all of the music you have to play in the concert, set it up, blow air through the horn, and finger every passage in the music while you are doing it. Go through every piece, fingering it and blowing air through it, and by the time you have done that, you feel so calm, you absolutely have erased all of your nervousness. And you have gone through all your music and mentally thought through everything. That is the best thing I have found to do. All of the deep breathing is what calms you.

You have led a rich and rewarding professional life.

Yes, it has been great I think because I enjoy doing a lot of things. Once, one of my friends from Aspen said, "Well, you are too easily satisfied. You can be happy doing anything. You might miss an opportunity because you are not picky enough." I've thought about that many times and I think that is an asset, that I enjoy many aspects of music. I enjoy going to concerts as much as performing in concerts. It always surprises me that so few musicians I know attend many concerts.

Well, if you are performing a lot, sometimes that is the last place you want to go. Right, and it is expensive. I remember hearing a member of the San Francisco Symphony standing at the ticket office saying, "There's no way I could afford to buy tickets to our concerts."

Do you ever look back at your experience with the San Francisco Symphony and wonder, what if the conductor hadn't been the way he was? Do you ever wonder what could have happened? Yes, I spoke to that just the other night. My son and daughter-in-law were talking about how they were worried about being laid off. I said, "I was laid off once and that is the best thing that ever happened to me." I would have been, probably, still playing and working on that San Francisco Symphony schedule. I know exactly what it is. It hasn't changed much. It is brutal and it changes your attitude to music to do that at an on demand basis for that long. It changes how you feel about music.

I think being first trumpet would have been great. I remember a concert where I was playing in a Brahms Piano Concerto, which has hundreds of measures of rest before you play anything. I was thinking to myself, "When is this going to be over?" At that moment I sat up and thought, "Whoa, this is not the way I want to feel about music." So, I knew early on that I was in the wrong place. Now, if I had become the associate first trumpet, I suppose that would have made a big difference in how I felt about the position. Having the opportunity to pursue a variety of musical paths has always been important to me. The Oregon Symphony scheduled allowed me to develop my interest in baroque and renaissance music. That is where I laid the foundation for my studies at Stanford. A full-time orchestra such as San Francisco Symphony does not allow you to stray too far from your main task of being a symphonic player.

There was a certain amount of pain about not being asked back, but I've had a lot of playing and as much music as can possibly be fit into a life, so that's been good. I've been able to have a family. Looking at it from my point of view, everything has worked out just fine. 
What professional goals do you have at this point?

I will at some point retire from conducting the symphony. I enjoy playing cornetto as often as possible. With the symphony, there are a lot of responsibilities that take up a lot of time. I know from past experience that when you give up an orchestra, you get a lot of time back into your life. Continuing to teach will be part of my work, and time to do more composing is something I look forward to.

Playing-wise, recently had to decide if I wanted to put out $\$ 4,600$ for the latest model reproduction of a natural trumpet that everybody else is playing. It is awkward for me to hold, and it excited a bout of tendonitis in my left arm. It made me think, "I play just fine on my threehole Egger Baroque trumpet; I'm not going to change now." If someone needs me to play trumpet, I'll play if I am available. I'm not going to challenge the newcomers with the fabulously expensive instruments. They sound wonderful, they play great, and it is fun to be in the section.

What are your non-musical passions?

We love our two Siamese cats. We enjoy being members of the Morgan Car Club of Northern California, and driving all over northern California on the runs and events that take place monthly. I was even the editor of the Morgan Club newsletter for two years! We really enjoy our home and yard, which someone recently described as "Atherton jungle." We have a very comfortable place here where each of us has the perfect set-up for pursuing our many interests. Our children live nearby in San Jose in the South Bay and Albany just north of Berkeley, so we see them usually once a week. I enjoy photography, especially with the advent of digital cameras. If I have a stretch of unscheduled time, I love playing the piano. I really enjoyed doing ceramics in the early ' $90 \mathrm{~s}$. I look forward to doing more with clay when time allows.

Do you feel that you were a role model for other female trumpet players?

I think that I probably have been. I am always pleased if someone tells me that they were inspired by hearing me play or by my accomplishments. I've heard back from more guys that I've inspired than women. Today young women generally feel empowered to do whatever they want to do. Their sense of empowerment derives directly from the experiences of those of us who have gone before them. I do have one student who is doing really well — probably the best young woman I've ever had as a student. I think she has observed that I have a very enjoyable life as a musician, and she would like to be able to have the same kind of life. I think that in general, yes, I have been in a position to show young musicians the way to make a life as a musician. I didn't get as far as the New York Philharmonic as a trumpet player or a conductor, but my career has taken place at a time when audiences have been very interested in seeing that women are taking their rightful place in the symphonic world as players and conductors.

Did you attend the International Women's Brass Conference?

I did. I went, I think, it was probably the very first one-around 1991. I played a twenty-minute program. That was very inspiring to meet and hear so many fine women brass players. I have not been able to get back to subsequent meetings of the IWBC.

What was your impression of the conference?

One of my strong memories from the IWB Conference that year was of listening to the kind of playing that wafted out the dorm rooms over the campus. I remember in particular hearing a 
gorgeous jazz solo - a warm, strong, singing tone pouring out of a window. It stood out in stark contrast to the kind of playing you hear at an ITG conference...higher, louder, and faster!

I especially remember Barbara Butler's beautiful playing in a brass quintet. It was the first time I had ever heard Carole Dawn Reinhart, who played with her brass trio. She was great and gave a very interesting lecture about her experiences. They had a session that year where women shared their experiences of being discriminated against and describing the difficulties they have had in their careers because of being a woman. It was really distressing to me to hear what other women had gone through - a very emotional hour of sharing! I have always known that my opportunities were likely to be limited by the fact that I was a woman. I was always aware that I was breaking new ground everywhere I went as a player and conductor. And I have always known that I have been very, very fortunate to survive in an environment that was not always supportive of women seeking to win certain male-dominated positions in the music field.

The "behind the screen" audition procedure in San Francisco was an equal opportunity destroyer for all of the musicians who won the audition that year; even the men weren't rehired. The conductor simply did not want to hire anyone he couldn't see, and he certainly would not have hired a woman brass player if he had known who was auditioning. I never nurtured a bad feeling or an unhappy attitude about that, or about men, or about treatment of women. I guess I moved on and said, "That works. That didn't work. That was good. That wasn't as good."

After I had played in San Francisco for a few months and was looking around for other opportunities I took an audition for principal trumpet with a major orchestra. After the audition took place, I heard from three different rumor sources that I had won, but no word of that ever came from the orchestra. Weeks later, confirmation came from the orchestra that I did not win. However, nine years later when I was in Wisconsin performing at the ITG conference, a man introduced himself and said he was the out-going principal trumpet who ran the audition, and that I had actually won the audition, but the conductor had refused to hire me saying that the orchestra already had too many women. It is one of the few clear-cut cases of sexual discrimination against me I can site but the nine-year gap made it a moot point. It is a sad story, but I have always been happy I did not have a reason to move to that city!

I definitely had advantages because I was a woman. I won the assistant conductor position with the Oakland Symphony largely because the conductor wanted to have a woman among his three assistants. That conducting appointment launched me as a conductor in the Bay area immediately!

I had a manager for a period of time, and the only engagement I ever had from him was conducting the Seoul Philharmonic in Seoul, Korea. They wanted a western woman conductor who could conduct, perform on an instrument, and do musical arranging. I was perfect. I was exactly the person they wanted. It was so exotic to feature a woman as a conductor; they knew their audiences would really go for that. And it was true - the concerts were sold out! I did many symphonic pops arrangements, I played trumpet solos, and I conducted the orchestra. They asked me back eleven times. That was one experience where being a woman was definitely an advantage. 


\title{
Susan Slaughter
}

\author{
Interviewed 24 February 2009
}

\section{Can you tell me about your family?}

I have two older brothers. We are all six years apart. I am the youngest. My mother played a little bit of piano. My father could sing a little bit. My middle brother, the one closest to me in age, played piano pretty well. He took piano lessons and I idolized him. Although he was six years older than me, he taught me everything he knew. He taught me basketball, football, and baseball. He was my playmate because we grew up on a farm. Basically my background is farming, not music. I started playing the cornet when I was ten. We did not have a band or any type of music program in our school. When I was ten years old, they actually hired a music teacher. My piano teacher, I think, had told my parents that I was very gifted musically, so they took me to the demonstration. I looked at all the instruments and because there had been people coming to my church and playing the trumpet, and I had seen this trumpeter on the TV by the name of Raphael Mendez, I was really taken with the sound and liked the instrument. When my parents said, "What would you like to play?" I pointed to the cornet.

I studied with the school band teacher. I remember getting off the bus when they gave me the cornet. Fortunately it was not too difficult to put together. I took it home, got off the bus, and ran up the driveway to the farmhouse where my dad was fixing dinner-my mother worked, so he would fix dinner and then he'd go back out to the field after we ate as a family together-I put the instrument together and handed it to him. I said, "Dad, how do I play this?" So he actually gave me my first lesson. He said, "I think you just put your lips together, blow into the mouthpiece here, and get kind of a buzz. I don't really know, but I think that will get you started."

What kind of performing opportunities did you have in your school band program? Did you get to do any solo playing?

When I went to high school, that band director was a brass player. He was a very fine trombonist and played trumpet pretty well. He taught me for two years and he had three of us that were very excellent trumpeters. He would provide opportunities for each one of us to do something in a solo capacity. Not necessarily every year, but he would have challenges, so we would prepare our music. Looking back on it, we were all pretty equal but I think he rotated us to keep us all working hard because we were in competition with each other. I think that when I was a junior in high school, my first solo was "Trumpeter's Lullaby" or something like that. I remember the three of us playing "Bugler's Holiday." This band director also went to a summer concert band in Indianapolis, referred to as the Phillips Concert Band. I was a high school student and he would take several of his really good high school students there. Playing in that band were people who played in the symphony. There was no summer work, so they would play the summer gig, and I helped fill out the trumpet section. That was a very good experience. I think one of the guys I played with just retired a couple of years ago from the Indianapolis Symphony. He probably wouldn't even remember me, you know, but I kind of remember him.

What was your band director's name?

Robert Miller 
Did you have the opportunity to take private lessons when you were in high school?

I studied two years with him, and then he felt like he had taught me all he could teach me, so he recommended I go down and study with the principal trumpet in the [Indianapolis] symphony. His name was Max Woodbury and he was too busy, so he gave me the name of one of his students and that's actually who I studied with. His name was Daniel Minter.

Do you remember specifically what you took away from your lessons with him?

Definitely. He taught at the Jordan College of Music, which would be like a community music school attached to Butler University. He studied with Max Woodberry and was a composition major. He would give me a one-hour trumpet lesson and a one-hour theory lesson. Because he studied with a symphony player, he knew that I needed to learn how to transpose, which I already knew to a certain extent from playing in church a lot. He taught me the literature.

We had pretty limited means, musically. The only classical recording we had in the house was Tchaikovsky's Symphony no. 4. Needless to say, I was thrilled to death the first time I got a chance to play it. Although I had wonderful opportunities, it was not the same as some people who grow up in a musical family, especially like string players who are exposed to string quartets and all sorts of things I had to learn when I got to Indiana University.

My teacher loaned me recordings when I was learning pieces. I started working out of the orchestral excerpts book when I was a junior in high school. My band director, Bob Miller, was very good at using concert music with us that was classical music. I don't really remember now all of the pieces that we did with him but they were very fine arrangements. Usually, we would get a first place at festival. I did know some pieces, like the "Water Music Suite," I just don't remember how I became acquainted with them.

When I was a junior in high school, I went to Indiana University's summer music camp and played the Water Music that summer. I was so green that when they said they were having a wind rehearsal, I missed the first rehearsal because I thought wind meant woodwinds. They said, "Where were you?" and then "Winds means brass in an orchestra rehearsal." I didn't know to ask because I had never experienced it before. They let me come back the next summer, so I guess it was okay. They gave me a $\$ 50$ scholarship to go to IU.

Did you take lessons at that summer camp?

No, it was just an orchestral camp. They had clinics but I don't recall if they offered lessons. I think it was mostly master classes and coaching but no private lessons.

Why did you choose Indiana University?

Well, up against Julliard, it was the next best school. It was a state school. I'm from Indiana. It was fiscally good; my parents could afford it. Put it this way, they did put me through school; I don't know if they could afford to do it. Mom made probably $\$ 5,000$ a year and my dad probably made $\$ 5,000$ a year farming, which means he'd turn it right back around to buy feed and seed to put in for crops. I don't know that we really came out ahead but at that point, tuition was probably about $\$ 2,000$ a year. That was still about twenty percent of their income. 
Did you work while you were in school or get playing jobs?

No. I think I did one or two jobs in Fort Wayne (Indiana) but not until I was junior or senior in college. My parents footed the whole bill and that allowed me just to practice and study. I did a lot of listening. I did a lot of listening to vocalists. I found that the flow of music was more natural when they would sing. That is what I wanted to mimic when I played, was the human voice.

Who was your instructor at Indiana University? Herbert Mueller.

What kinds of things did he teach you?

He taught me a lot more of the literature. He was very thorough. One of the important things he taught me was - he would have me play something. He said, "I'd like you to play through that again. Do you think you can?" I said, "Well, I'll try." He said, "Well if that is all you are going to do, then don't do it. If you are only going to try, don't do it." I said, "I'll try as well as I know how." He said, "No, that is not good enough. Tell me you will play through it again." So, I learned that I had to determine that I would do something. I could do it; I just had to set my mind to do it. He taught me a lot of things like that.

He was one of these people that had a perfect embouchure. He could take his trumpet off his face with an eighth note rest, come right back in on the note, and not miss it. He could just play forever, so his endurance was interesting. He caught one thing that we couldn't figure out, which I finally figured out about twenty or thirty years later. The lower teeth on my left side recede. You can't see that by looking at me. He said, "I can't figure this out but you are losing contact with your mouthpiece on your face. I can't figure out where it is." So, I've thought about that a long time and finally realized that in that lower left corner of the mouthpiece, I did not have a seal. When I could figure that out and fix it, then my attacks started getting better. I did pretty well for about twenty-five years.

How did you finally fix it?

I build these little inserts. It is like a temporary crown, and I slip it over the top of the teeth on my lower left side and that brings it forward. I no longer have Niagara Falls going down the side of my face when I'm tonguing.

Who were some of your peers at Indiana when you were there?

Floyd Cooley, tuba, who played in the San Francisco Symphony. Paul Krzywicki, former tubist with the Philadelphia Orchestra, recently replaced by a young woman. Doug Hill, horn player. Peter Gordon, another horn player, he is a freelance player in New York. Trumpet players ... a lot of them, especially graduate students, left IU and went into the service bands. That was during the Vietnam war time, so that was their only out unless they were married. So they were getting out, when I was getting out. I know one of them ended up playing third in the Atlanta Symphony for a long time. Ed Cord is at Indiana University. He was first trumpet in the Utah Symphony for several years. A lot of those folks that were with me ended up getting college jobs. 
I can tell you about some of the people that were at Tanglewood when I was there. Phil Collins was the first trumpet in the Cincinnati Symphony. He came here to audition and I won the job. Louis Ranger was at Tanglewood when I was there. I was there just one summer.

Who was your instructor at Tanglewood?

They didn't really have instructors per se but I took a couple of lessons with Armando Ghitalla who was the first trumpet in the Boston Symphony.

What was he like?

He was great. He shared with me his warm-up routine that he used for several years. It would take him ninety minutes to get through it. It was a pretty thorough routine and I think it is a good one. I've moved on from that, using other things that are similar. I also studied with Bernie Adelstein when I was playing first in Toledo for two years. When I was at Aspen I studied with Robert Nagel.

When you were at IU, what other performing opportunities did you have other than the orchestra?

I played in the opera orchestra, the contemporary music ensemble, in brass quintets, and brass choir.

Can you talk about your audition experiences?

When I was a senior in college I sent out thirty letters. From those thirty letters, I received three invitations, one to Milwaukee, one to North Carolina, one to Toledo. The first audition was in Milwaukee. I played very poorly, in my opinion. I still had two auditions lined up, and I thought, "Gee, I probably should have gotten a teaching degree." I went ahead and took those other two auditions. One was in Toledo and the last one was North Carolina. Toledo called me right away and said they wanted me to come and be their principal trumpet. Since that is the only job I was offered, that is the one I accepted.

When I was in Milwaukee, I heard the other trumpet players talking about the audition in Houston, and the audition in this place, and the audition in that place and I thought, "Well, they didn't write me back." So, when I got back to Bloomington, Indiana, I called Houston and said "I understand you have an opening there." They said, "Yes, we do." I said, "I sent you a letter, asking to be invited. Did you get it?" They said, "Yes, we did receive it." I said, "Well, I'm very interested." They said, "We didn't think you would want to come all this distance." I said, "Let me assure you, I am more than interested in your position and would love to have the opportunity to come and play for you." They said they would send me the information right away. That was 1967, and I am still waiting. So, that's the way it was. We didn't have Title IX. We didn't have any way to prove that we were being discriminated against. If I had the opportunity to go and play, I went and played. If I was denied that opportunity, I was simply denied that opportunity. Certainly, going to IU helped. Had I gone to the University of Missouri, they wouldn't have invited me.

What were some of your other audition experiences?

At one audition, I was told that it was a tie between me and a gentleman who was given the job, and they went with the gentleman because they felt that a woman wouldn't have the stamina to 
play the trumpet. That was with the Indianapolis Symphony. At the New York Philharmonic [audition], I was one of three finalists, Phil Smith, Louis Ranger, and myself. What I was told years later was that when I came out on stage to play the final round, Zubin Mehta was in the audience and said, "What's a woman doing up there? We're not going to have a woman in the brass section." So, that's what I found out years later. That was in 1977 or 1978 before they started using screens there. We were using screens in St. Louis probably by 1976-77.

You have been principal trumpet with a major symphony orchestra for thirty-seven years. How have you been able to manage the schedule and the demands over such a long period of time? Practice, practice, practice. Prepare way ahead of time. Rest, rest, rest. I don't do outside jobs and I don't do a lot of teaching. I've had maybe ten students over the course of my lifetime career of thirty-seven years that I've seen for private lessons and none of them all at the same time. The highest is probably two. I hardly teach.

Did you ever have problems with nervousness?

Definitely. In fact, not until the recent years have I really had that much confidence that I can do something. I used a lot of prayer and faith that this was the job I was supposed to be doing, and I would just pray that God honored those prayers. If you asked me if I could get through something, I'd say, "Okay, here we go. Yep, I think so." Even though my teacher used to try to teach me to be stronger with my conviction about playing, I still struggle with it from time to time.

One of my former students when I went up to the Teton-I would be out there four weeks and I would teach like crazy out there, so that is where I did my teaching from about 1989 to 199495- one of those students was a very good player but when she got in front of people, she couldn't pull it off. A few years later I had heard that she auditioned for and gotten into the Marine Band. I asked her one day, "How did you do it?" She said, "I got beta blockers, I took the audition, and I realized that I could do it." That's how she did it. Also, I talked to another person who plays in the Metropolitan Opera who takes them. People aren't really willing to talk about it, but I talked to this person and they shared with me what they did and said, "I couldn't do these Live from the Met broadcasts without some help. I would just be too nervous." She said, "I do take the beta blockers and I can do what I do that way. I don't get too nervous." I decided that I would try it, especially when we were going to take Petroushka back to Carnegie Hall for a second time. I thought, "Gee, I got through it once. Why do I have to play it again?" So, I asked my doctor if I could try it and he gave them to me and I've used them since then. It just takes the edge off. Otherwise, I start to panic and then everything closes down. It has helped me mentally. I didn't take anything up until about the last ten years.

Who are some of the women that have influenced you?

Ruth Still is probably the first female trumpet player that I met and she was an outstanding trumpet player. I met her at Brevard Music Camp in 1965. She was in the faculty orchestra. They had hired her to teach mostly the younger students. She was probably about the first female brass player I'd seen. There were two other women that played trumpet at IU: one of them was a very good player and the other was an average player. Other than just talking from time to time, we didn't hang out or talk about the problems that one's going to encounter. When I met Ruth, she spent some time with me, and I took some lessons with her on the side, so the main teacher 
wouldn't know. She talked about a lot of the barriers that she encountered. She had studied with William Vacchiano and she had gone to Julliard School of Music. She eventually went into composition and was a very good composer.

The people I have heard of but never met until much later, not until the 1980s, one was Barbara Butler. I'd heard about Carole Dawn Reinhart for a long time but I'd never met her until the first IWBC [International Women's Brass Conference] in 1993. The other person I'd heard about for a long time was Marie Speziale and I had never met her until 1993. Gail Williams, because she was in the Chicago Symphony, I knew of her. I don't think I had ever called her to get acquainted until we were putting the conference together. When we formed the IWBC, I asked her if she would be on the board of directors and she agreed to do that.

There have been five IWBC conferences. Looking back at the goals that you set at the first gathering of the board in 1992, do you feel you have achieved the goals that you set out to meet? One of the most important goals was to set up a format where people could come together and network. From that first conference came DIVA [an all-women jazz big band]. Another group that came out of it that I was involved with was Velvet Brass. We put together a brass quintet with Velvet Brown [tuba]. I'm certain that there are other good things that happened from that [conference] and I'm not aware of all of them. In 1996, I organized Monarch Brass and we took our first tour that summer. That was another goal that we had, to put together an all-women brass ensemble and it was a super group. That was very successful. In 2000, Marie helped to put together a Monarch Brass CD. Each conference we have had a Monarch Brass group. In 2000 we also did a Monarch Bass quintet performance at Washington, D.C.'s National Museum for Women in the Arts. They have a concert series and they invited us to do that. Another goal was to have a newsletter, and Susan Rider and Laurie Penpraze currently publish it twice a year. That is a good newsletter.

I had hoped that we could set up something through our website where women faculty college professors could invite other women to come to their schools to perform in the hopes that they in turn would be invited back to the other person's school, so they could show the school that they were in demand as performers. That has never come about. People are funny. They act like that's not going to help them, that that's not any good. I'm not in teaching, so I didn't try to push it through. I thought that if it was really going to help, someone would have picked up on it but they haven't. You can throw a lot of ideas out there; for certain some of them aren't any good, so maybe that was one that wasn't good.

If we don't help each other ... The guys aren't going to help us. They do all their networking; they're smart. We're not that smart, sometimes.

What do you see for the future for the IWBC?

I've started to step back and let other people take over. If an organization relies so much on one person then it has no life when that person dies. Also, it is possible that we will develop into a perfect society where there will be no discrimination of any sort and we won't need the IWBC. On the other hand, I don't think that will ever happen. Guys like to hang out with guys; for the most part women like to hang out with women. The IWBC needs to have a life of its own and we need to come up with a new long-range plan, I think. They tried to do a tour but the economy just 
sank. The people who thought they had money to pay for it, that money was taken away from them.

I'm hoping the next conference will come off. We've got the money raised through the Holiday Brass concerts. I think that is the greatest concern. Other people haven't stepped up to the plate and offered to do the Holiday Brass concerts so we can raise money. I'll give them the whole package. I'll give them the program, the music. All they have to do is find the place to do it. I tell them how to do it. They have to do a lot of legwork. I tell them how to get their audience there, supply the music, and supply the program. I'll even come out and help put it on the day they are going to do it. People have to say that they will do it. We give them starter money, $\$ 5,000$ to cover their expenses up front. If they don't make any money, we don't ask for the money back. The first year, Baltimore broke even. I think the second year they made $\$ 6,000$ with their ticket sales, so they covered the $\$ 5,000$ we gave them. This year they cleared $\$ 10,000$. After expenses, we make between thirty and forty thousand here in St. Louis.

How many concerts do you give?

I do two on the same day. Now in Baltimore, because they use so many service people, the only time that's available to them is in the evening. They can't do two concerts.

\section{How many musicians are involved?}

In Baltimore I think they have around twenty. In St. Louis I have about twenty-six musicians. We play to two sold-out audiences, about 3,500 people in two shows. It is always good quality music. So, that is what concerns me more. This will be our eighteenth year this fall for the Holiday Brass concerts. I'm going to try to do twenty years and after that I'm probably going to need to stop. Somebody else needs to pick it up, because if we don't raise the money, we can't pay for the conferences. We are going to give away about $\$ 35,000$ in 2010 in scholarships. We usually pay about $\$ 50,000$ to help pay for the conference because we can't charge enough to make it break even. We put out about $\$ 75,000$ and it takes me three years to raise that. We are doing well. We have money in the pot and we should be good for about another three or four years.

That is my greatest concern, that financially nobody will step up to the plate and figure out how to raise money. It doesn't have to be a holiday concert.

Do you think things have changed at all for women as trumpet players since the first IWBC conference?

I think that Title IX helped a lot because they couldn't deny us from coming. I think that curtains helped some. Frankly, I never thought there would be a female tuba player in a major symphony in my lifetime but that happened in the Philadelphia Orchestra. Besides myself, there is still not another principal trumpet in a major symphony. What I think the IWBC allowed us to do was showcase women performers. Women then began to believe in women. To be honest, when I brought people here [St. Louis] in 1993 to perform, I had no idea what level they were going to play at. I was blown away by the level of playing. I hadn't heard other women play at the level I play at, or Barbara Butler, or Marie Speziale. I just had not heard them. Velvet Brown, I asked her to be on the board of directors, she is a founding member of the board of directors. I asked her because I knew her name and thought she was a good player but I didn't hear her until the 
first conference. I was blown away. Jan Duga, the same thing. The trombonists. Abbie Conant, she did that first performance where she portrayed a woman who had been discriminated against. It was based on her experiences with the Munich Philharmonic. She just blew me away. It was terrific playing. I just had no idea.

It is interesting that it was a surprise to you, too, that there were so many outstanding female performers out there.

That is what I was hoping for. In 1996, at Indiana University, David Hickman and Dan Perantoni organized an International Brass Conference and he did not have one woman brass player featured. I was on the ITG [International Trumpet Guild] board, so I called him and said, "Dave, Wow, what a line up you have here for the conference. Congratulations. I notice there are no women and I notice there are no African Americans." David said, "I just don't know any women players." I said, "Alright Dave, you know we had a wonderful conference here in 1993. I'm going to fax you the names of all those women brass players." I faxed him thirty pages of bios. He invited Velvet [Brown] to play and I think Ava Ordman to play trombone. So, those were the two people he conceded to include in his big thing. Of course they played at odd hours, 9 a.m. and all that, but still he did it. Because I knew of them, I could recommend them and send them on to him.

I do think that because of the IWBC that the other conferences have been more open, with the exception of the horn players. They seemed to be more open to begin with. The other conferences have been more open to invite women players to come because they have either heard that they were great at our conference or they were willing to take a chance. That is what I think the IWBC has done, opened the door for women to perform at the other conferences because we had them here.

We never had Carol [Jantsch] here, the tuba player but she certainly knew about the IWBC. I imagine that people talked about it with her, and she was encouraged. She is just a phenomenal player, so she went for it. For her audition in Philadelphia, they said, "You've won the audition but you don't have any experience. We're not going to give you the job." The second time she won the audition they said, "Alright, we're not certain that we should give you the job. We want you to come back and play the summer with us." She played the summer and finally they gave her the job. But she still had to prove herself. But, they were willing to listen; they were willing to be open-minded. I don't know if - Dick Williams is the principal oboe player in Philadelphia - I don't know if he was on that audition committee, but he was here for about seven or eight years when I was principal trumpet. He would have an open mind, and maybe he helped other people have open minds.

So, I think the IWBC really has served a purpose. It's brought all of us together. It's given us the courage to speak up, to go for our doctorate or try to do recitals or whatever a person needed the courage to do and they've stepped out and done it. All of us are there on the sidelines saying, "You go for it."

Were there any other women in the orchestra in St. Louis?

When I came to the orchestra, there was somewhere between ten and fifteen women in the orchestra. The St. Louis Symphony was more open to hiring women, even at that point. In the 
early 1980s, a woman was hired for principal second violin. She and I would talk a lot and we hung out together a lot. Now there are about fifty percent women and fifty percent men. It is very even now. It is amazing now to see how many women are there, and that is really due to the curtains.

You've mentioned your faith a few times and how that has helped you in your career. Can you speak to that a little bit?

My faith is Christian background. I grew up in one denomination and just recently changed to another denomination. I grew up in the Nazarene church and just recently joined a Baptist church. You probably heard about this shooting that occurred in St. Louis, in Kirkwood, that's the little town I live in - last year or the year before. This Baptist minister and the church have been very involved in the community, trying to help it heal. Even before that happened, they were doing things in the community. To me, that's really what it is all about. It's not between the four walls where you sit and worship on a Sunday; it's about taking your faith outside. Part of my faith was established well before that, back in the 1960s.

In my mind, I've been given a lot of talent, and with that talent comes a lot of responsibility. My job is to dedicate that talent back to God. When I came here to St. Louis, I wasn't certain I was supposed to come because it was for the fourth trumpet job (that was in 1969). Then I felt that that was where I was supposed to be, so I came. Then when the first trumpet left, I auditioned for the position and got the position, I felt that this was where I was supposed to be. I'm not certain that in 1972 or 1973 that they would have automatically hired a woman to play first trumpet. They weren't doing it, even in the late 1970s. They are still not doing it. I just felt like the door was open and this was my calling, if you want to put it that way.

When I started getting questions in the Tetons from other women brass players there, "Have you ever met Gail Williams? Have you ever talked to Marie Speziale?" I said no and I didn't really have a good reason why. Ramona Galey came up with the idea. She said, "Wouldn't it be neat if we had a conference where we could all get acquainted, do some networking and talk about our problems and share our solutions with each other. I thought that was a wonderful idea.

There is a story in the Old Testament about putting out a fleece. So, on my fleece was the survey. In 1991, I came home and put out a survey. One of the horn players, a man in the orchestra, helped me do it. We sent out 1500 surveys. We sent them to what we thought were female names in all of the existing brass conferences. If it said Lynn, we sent it. One guy name Lynn sent it back saying, "I'd be happy to fill this out. I love the idea but I'm not a woman." Out of those 1500 , we got back 500 surveys. If you talk to somebody commercially, and I talked to people at the symphony who do surveys all of the time. I asked them "What is a good percentage of return?" They said, "Two or three percent is considered to be very good. Ten percent is considered outstanding." We had over thirty percent. That was a mandate. Out of those 500 surveys, 490 said yes, please try to establish a conference. Try to do something. Two or three said, "We don't want to rock the boat." Two or three said, "No, we don't need it." I thought that I had a mandate and God is leading again and I should try to do it. So I proceeded to try to do it.

St. Louis had just hired a first trombone and his wife was an arts director who had uprooted herself out of Washington, D.C., came to St. Louis, and was looking for work. She heard about 
what I was trying to do and she said, "Could you use some help?" I said, "Absolutely." She did most of the work and I went out and did the fundraising. In 1992, we had our first Holiday Brass concert. We did that to call attention to the fact that we were going to have a conference in St. Louis in 1993 and that we were raising money. All the brass players donated their services and we made about $\$ 6,000$. I went knocking on doors and I went talking to board members. I asked the symphony if I could approach some people. I don't remember how much the first conference cost and I probably paid for a good chunk of it out of my own pocket but that was okay. I was doing what I thought I was supposed to do. If you give of yourself, I find you end up receiving much more than you could ever give away. I just try to do what I think I'm supposed to do. 


\section{Marie Speziale}

23 December 2009

Where were you born and raised?

I was born in Brooklyn, New York, but grew up in the Latin area of Tampa, Florida, in an area called Ybor City. In some respects it was basically inner city Tampa, Florida.

I read in the interview that you had with Karen Gustafson that your father was a musician. Was he the one who helped you get started on trumpet?

My dad played piano by ear. He didn't know how to read a note of music. He was self-taught and played banjo, mandolin, guitar, and piano. Piano was not an instrument he played when he lived in New York. He took to the piano when we moved to Florida and heard all the Latin music. That really engaged his curiosity. He started teaching himself how to chord on the piano. Before he knew it, he became probably the only Italian playing in any of the community Cuban bands. We had a piano in our home, and as a child, I used to pick out little tunes on it, although I never showed any kind of passion for the instrument. It wasn't like "Oh, I want to play the piano!" I just enjoyed myself. I would jump up on the bench and find my little notes and put tunes together.

The first time I heard the trumpet live was in my living room. The Latin band my dad played in would rehearse at our house. Somewhere along the line I had heard the instrument but maybe it was the combination of seeing the person playing, hearing the instrument up close and live, and actually seeing the instrument that prompted my interest. I thought, "Oh, that is what I want to do. That is what I want to play!"

Who was the trumpet player?

He was someone in the community. There were a lot of musicians in the community that came over from Cuba. A lot of them played the percussion instruments, but there were trumpet players in the crew, and other instrumentalists, too. The Cuban cojuntos in Ybor City consisted of three trumpets, keyboard, bass, a variety of percussionists, singers, and a couple of guitars. I suspect that that was the cut-rate version back in those days. I think that in Cuba their bands were probably larger, and included trombones and saxes.

Did anyone think it odd that you chose trumpet out of all the possible instruments?

I was about ten years old when the school I attended, V.M. Ybor Elementary School, hired a music teacher for the first time. Up to that point we didn't have any organized music classes, and then they hired a gentleman to start a music program at the elementary school. They gave all the kids a battery of tests, and I scored the highest in the school. Mr. Comparetto called my folks and said, "Your child apparently has some talent, and she is showing an interest in wanting to play. She tells us that she wants to play the trumpet." My folks said, "That's great but we can't afford an instrument. There is a piano at home. If she wants music lessons we can do that, but she'll have to play the piano." 
So, I took piano lessons for a while, but it wasn't for me. I just didn't have that passion for the instrument, maybe because I'm not very coordinated. It was okay, but it just didn't grab me the way the trumpet thing was grabbing me.

It was actually my grandmother that finally talked my father into it. She said, "She needs to play an instrument." So, they found a relative of a relative on my mother's side of the family that had once played a cornet. This gentleman graciously allowed me to borrow the instrument. It was stuck in his attic somewhere. I remember having to hold the case together with my dad's belt. The valves were frozen, and it just looked awful. It wasn't exactly the most beautiful instrument, especially compared to the nice, new, shiny instruments some of the other kids had. I had the old beat up instrument, but I didn't care. I was just thrilled to be able to play the cornet.

Was anyone else in your family musical?

I would say that the biggest and earliest musical influence was my dad. My mother had taken some music lessons as a child. My sister also studied piano for a while, but was not very seriously into it.

Mr. Comparetto told my dad, "Look, this kid is progressing very quickly and I recommend we find a teacher for her." Both he and my father started making inquiries in the music community regarding some possible teachers for us to consider. The same name kept surfacing. That name was Bob Price. When my dad first called him, Mr. Price told my dad that he had a full schedule, and that he might not be able to take me right away. He said, "I'd be glad to hear her play, evaluate her ability, make some suggestions, and we'll go from there. Then, maybe when I have an opening, I can fit her in."

So, my dad arranged a meeting with him. I'll never forget walking into the Sulphur Springs Junior High School band room on a Saturday afternoon to meet Mr. Price. He put me through my paces. He ended up making time in his schedule for me. He told my dad, "Look, your child has a lot of potential. I would like to work with her. Let's see if we can get started." I was really fortunate. I thought I was going to have to wait much longer than I did to get into his studio.

What specific books or methods did he use with you in your lessons?

He started me right off with the Arban book! After I began developing as a player, he used some of the better supplemental methods: Schlossberg, Smith Top Tones, Glantz Studies, etc. He was phenomenal at teaching the fundamentals, and not just to trumpet players. He had a real gift for teaching the fundamentals of music to all instrumentalists. Some years ago while rummaging through childhood pictures that my mom had, I found a picture of the V. M. Ybor Elementary Band. There we were, about fifteen or sixteen of us, all lined up across the front of the stage of our local theater where we performed. As it turns out, in that little inner-city elementary school band that I played in starting at age ten, there were two of us that wound up sitting in major symphony orchestras. Both of us had the same trumpet teacher, Bob Price.

Who was the other one?

Adele Sanchez, who played principal in the National Symphony for so many years, and is now the Associate Principal there. 
That is amazing that such a little school produced two such wonderful performers.

I know. What are the odds? Especially since neither one of our families could probably afford an instrument, much less lessons. And we both have enjoyed successful careers, thanks to Mr. Price's influence.

That speaks a lot about people who are dedicated teachers at the junior high and high school levels who are not always on the forefront.

That's exactly right. There were no shortcuts. It was all about doing everything, and doing it really well. His emphasis was on tone- a phenomenal emphasis on tone. It wasn't "Faster. Higher. Louder." Yes, you have to be able to play faster, but it isn't going to sound solid if you don't support it with a good tone.

By the time I started with Mr. Price, I knew all of my notes and rhythms so he put me right into the Arban book. We covered the Arban book. And I do mean cover. There was no stone left unturned. We didn't work in just one section at a time. For each lesson, he would assign a line or two in many different sections. By the time I was through junior high school, I had pretty much covered that entire Arban book, and knew how to play in all the keys. He would also assign memorization each week. There's no way to begin to tell you what a tremendous influence he had on me. I had enormous respect for him while under his tutelage, and even more so since becoming a teacher. I owe a great deal of my success to him. He was a wonderful teacher and gentleman.

What motivated you during this time to practice so much?

I got a lot of attention because it was so unique, a little girl playing trumpet. As a kid, I was my dad's shadow. When the band wasn't rehearsing at my home, I would go with him to wherever they were rehearsing, and would just sit there and listen. Earlier in the interview, I told you that I used to pick out tunes on piano. Well, I started doing that on the trumpet. One afternoon my parents came home from work just as I was finishing my practicing. On that particular day, I finished my practice session with a tune that I had heard my dad's band play earlier in the week. I had picked it out by ear. This was before I started studying with Mr. Price. Unbeknownst to me, my mom and dad were in the driveway listening. My dad was telling my mom, "She's playing what we rehearsed a couple of nights ago." He came in and said, "I heard you playing one of the songs that the band rehearsed the other night. Do you like that song?" I said, "Yes, I like it a lot." He said, "Would you mind playing that for me?" So I played it for him, and he gave me a couple of pointers.

A few weeks after that, my dad's band, the Cuban cojunto, was scheduled to play at a benefit dance for polio. It was an outdoor patio affair at the Cuban club, one of the many clubs in Ybor City, where all the Latin bands played. There were two or three bands playing that evening, all donating their services. The place was packed. I went to this benefit with my parents, and actually sat on the stage with the band.

In the middle of their set, my dad said to me, "Okay, we are going to play Los Dantes soon. Do you want to play with the band?" I said, "I can't, Dad. I don't have my cornet." He said, "Oh, I have your cornet. Let me know if you want to play?" So I said, "Sure!" Of course, my dad had already talked to the trumpeters about this to make sure they were okay with having me sit in. 
How old were you then?

About eleven years old, at the most twelve. I was still relatively new to the cornet. I sat next to the trumpet players, and I played along with them. I guess the folks that were dancing looked up, and realized that there was a kid on stage playing. In Spanish, they started shouting, "Leave her alone. Let her play." So the trumpet players dropped out, and there I was, this little tyke, playing with the rhythm section! I hate to sound braggadocios but I guess it brought the house down. I was hooked! All that applause was for me. I thought, "Wow, this is fantastic!" I was off and running.

It sounds like your dad was quite supportive of your music.

Both of my parents were. They made some real sacrifices, some that I was aware of as a child, and some that I didn't learn about until I was much older. I think about the extraordinary lengths they went to, to give me my education in music. I was so blessed.

When I was ready to go to junior high school, my dad and Mr. Price both felt that it would be great if I could go to the school where he was the band director, because then I would be under his tutelage more than just once a week for lessons. The school was pretty far from where we lived. Somehow, we got permission to change school districts. There was no convenient public transportation available from Ybor City to Sulphur Springs, so it meant that my dad would have to drive me to school.

Both of my parents were second generation Italian Americans with third grade educations. They worked side by side, for over thirty years, making hand-made Cuban cigars in one of Tampa's cigar factories. It was a sweatshop. In order to get me to school on time and not miss work, dad would go into work an hour earlier, so that he could get all the molds ready for my mom to fill. Then, he would come to the house to pick up my mom and me. He would take her to the factory, take me to school, and drive back to finish his workday. After work, he would drive back out to Sulphur Springs to pick me up from school. He did that for three years of junior high school, and one year of high school, for every working day.

He must have loved you very much!

Yes and I loved him.

My dad really wanted to be a musician. Music was his first love. Unfortunately, he was supporting his family by the age of twelve. He was part of the generation that inspired child labor laws. So, when I showed an interest in music he was thrilled.

So at the time you were in junior high school and high school, what kind of performing opportunities were there for you?

I had so many opportunities to perform both at school and in the community: concerts, benefits, parades, variety shows, dances, festivals, church services, and funerals. You name it; I did it. I never turned down an opportunity to play. One of the most significant performing opportunities came from Mr. Frank Czolgocz, public relations director for the Hillsborough County School System. One of his responsibilities was to spot and feature gifted youngsters from the public schools, be they scholars, musicians, artists, dancers, or athletes. He did this by way of a weekly 
radio show, which he hosted. In his travels throughout the area schools, he spotted four of us that he thought might have some potential as a group. We were all from different schools, two of us in junior high, and two in high school. He thought, "I should bring these kids together and see what happens." He talked to all four of the families and told them what he wanted to do. Then he arranged a time for us to get together. The instruments we played were accordion, organ, string bass, and trumpet.

\section{An organist?}

Yes, one of those Hammond organs. We obviously had to meet at her house, because she was the least mobile. So, we met and started faking tunes. Just started jamming!

Mr. Czolgocz invited us to play on his radio show. On the show, he interviewed each of us and gave each of us a solo feature. My dad accompanied me for the program. After everyone was interviewed and featured, the four of us played together. At the end of the show, he sent out a feeler to the listening audience. "If you like the sound of this group, let us know, because we would like to feature them more." There was such a really nice response from the community that we decided to keep the group going.

We wound up with our own television show. We four kids would go to the studio two to three times a week. The first day at the studio we would audition local talent, and decide for ourselves who we wanted to feature on the next week's show. We would start rehearsing with them. We learned all about how to play in front of a camera, camera cues, and all sorts of stuff.

In the mid 50's when television was relatively new, NBC opened an affiliate station in Tampa, WFLA Channel 8. One of the producers at the station had heard us on radio, and was interested in producing a teen show featuring our group. So, there we were with our own television show. We were responsible for auditioning local teenage talent, formatting the program, determining which pieces and keys worked best for continuity, timing, deciding featured solos in the group, the whole nine yards. What a fantastic opportunity to learn some very valuable lessons about how things worked both in front and behind the camera.

My success and popularity on the Date on 8 show led to another, really wonderful experience. The NBC Today Show with Dave Garroway decided to do a live broadcast aboard the Gasparilla Pirate Ship, one of Tampa's more popular tourist sites. I think it was one of the earliest shows to be broadcast away from the NBC studio in New York. The producer of the Date on 8 show told them about me, and they invited me to appear on the show. NBC had a professional band there for the show. They were the ones that accompanied me. We even had an impromptu jam session during the show. Jack Lescoulie, Dave Garroway's sidekick, was a trombone player, so he borrowed the trombonist's instrument, and we wound up playing a few choruses of "When the Saints Go Marching In."

What a great experience! What other opportunities did you have? I was playing all over the place, did all sorts of things. I volunteered, would go to the VA hospital, and volunteer there. If anybody called, I was there. 
What types of music did you play?

Mostly Cuban music with my dad's cojunto. No hint of classical. To me John Philip Sousa was classical music. My orientation was strictly commercial and Latin music. I didn't know Mozart from Mahler, or anything else. If somebody had said to me as a kid growing up that I was going to make my living sitting in a symphony orchestra, I probably would have laughed in his or her face.

When did you know that you were going to pursue trumpet performance as a profession? I was so naïve; I don't know that I ever gave it much thought. I don't think there was ever even a question. The trumpet was the center of my universe. I was simply going to play trumpet. Period!

My dad was really good about making sure that he kept a clamp on my head. He didn't want me to get a big head from all the attention I was getting. He'd say, "You make sure that you treat everybody with respect." I had that ingrained in me. "You've got to be a good citizen. Don't let all this attention go to your head." Both parents taught me to appreciate what I had, and helped me keep things in perspective.

\section{How did you end up at Cincinnati College-Conservatory of Music, coming from Tampa, Florida?}

While in junior high school, I attended the five-week music camp at Florida State University. Because of my age category, I was assigned a graduate assistant for my lessons. Robert Braunagel, the trumpet professor at the university, got wind of the fact that there was a young hot shot at the camp, so he invited me to come in and play for him. He took a real interest in me, and gave me lessons every week, even though he technically wasn't teaching at the camp that summer. In fact, I was chosen to play a solo with the high school band at the final concert of the camp. The solo was "Napoli," and Dr. Braunagel coached me for that performance. I really enjoyed working with him, and he is the one who first told me about the Conservatory. He was a graduate of the Conservatory, and a good friend and classmate of Al Hirt. That impressed me.

Coincidentally, Robert Scott, one of Mr. Price's best friends and fellow band director in Tampa, was also a graduate of the Conservatory. I kept hearing really good things about the school from him. One of his former horn students was attending the Conservatory at the time, so I took advantage of finding out more about the school from her. The more I heard about the school the more interested I became. In my senior year, the school's dean of admissions came to Tampa to hold auditions. I auditioned for him, and was accepted right on the spot. I auditioned for very few schools. In retrospect, I guess I just had my eyes trained on the Conservatory. I really had my heart set on going there, even though I had never even seen the school.

When you arrived at the Conservatory, who was your trumpet instructor and what kinds of music did you study?

I studied with Eugene Blee, principal trumpeter of the Cincinnati Symphony Orchestra, and professor of trumpet at the Conservatory. Let me tell you who some of his other students were. I was the first in line to get a major orchestra job. After me came Steven Pride, in the Cincinnati Symphony; Mark Ridenour, in the Chicago Symphony Orchestra; Jim Wilt, in the Los Angeles Philharmonic; and Mike Miller, in the Cleveland Orchestra. Are you getting the picture? 
Yes, what a teacher!

You bet! Not a well-known teacher, but he's got some former students sitting in orchestras around the country, and in Europe.

What kinds of things did he teach you? What do remember specifically learning in his studio? Thanks to Mr. Price, I had all the fundamentals in place when I arrived at the Conservatory. Mr. Blee introduced me to the Charlier, the Bitsch, the Vannetelbosch, the Caffarelli, and a number of other really important studies. We worked on solo literature, transposition, and orchestral excerpts. We spent a lot of quality time focusing on musical interpretation, and developing a command of the different styles of playing.

As a freshman, I accomplished something that no one else had ever done. On the strength of my auditions, I wound up playing principal in all four of the major ensembles: orchestra, brass choir, wind ensemble, and band. On one hand I was really excited and flattered, and on the other, a bit nervous. If you were appointed principal, it was for the whole year. It was a huge assignment for a freshman, but one that I relished.

How did your peers respond to you?

At first, there were some bruised egos, particularly at the grad level. Once we started working together and got to know each other, we realized that we had one common goal, making music. Things just fell into place. I was keenly aware of the sensitivity of the situation, and tried to be as helpful and supportive of the others as I could. I can say in all honesty that none of my peers were ever nasty to me, or behaved obnoxiously. I had four wonderful years at the Conservatory. I could not have made a better choice of schools.

You could have gone the commercial route or the classical route. I know you've maintained both throughout your career. What made you choose the classical side as your main gig?

I'm not sure that I chose it. I think it chose me. When I left Florida, I knew I was going to go to the Conservatory to become a better trumpet player and musician. I'm not sure that I had a game plan beyond those four years. Somewhere in the recesses of my mind I thought I would graduate from the Conservatory, go back to Florida to teach and play jobs, never ever considering the prospect of becoming an orchestral musician. It just happened. I was at the right place at the right time and, fortunately, I was prepared. That whole thing with the symphony fell into my lap. The first time I played with the orchestra I was a featured soloist. I was just nineteen years old.

What did you play with them?

I played Rafael Mendez's "La Virgen de la Macarena," the Bullfighter's Song. It was a Christmas program conducted by Haig Yaghjian, associate conductor of the symphony, and conductor of the Conservatory orchestra.

In my sophomore year, I had some opportunities to play extra with the CSO. Then in my junior year, the second trumpet player became quite ill at the beginning of the season. I remember getting a call from my teacher one afternoon. I was in the dorm. "The orchestra is playing a concert tonight just north of Cincinnati. The program is the Bach Second Suite, "Three Cornered Hat," and the Prokofiev fifth symphony." I didn't know what he was talking about. I was just starting to learn about orchestral music, so these pieces were not familiar to me. He said, "Mike 
is quite ill, and we need someone to sight-read the concert on second trumpet. I got a crash course from my teacher before we went out, and he told me what to look for. I didn't own a D or piccolo trumpet. Fortunately, I had been doing some work on his D trumpet, so at least I was familiar with the instrument for the Bach. The rest was just a matter of sight-reading.

Maestro Rudolph, conductor of the symphony, was impressed with my work on the concert and told the personnel manager to make arrangements to hire me for as long as needed. I wound up playing most of the season with the orchestra including tours, recordings, and a Carnegie Hall concert.

Then in my senior year, the third trumpet player became ill, so I wound up playing almost another entire season with the orchestra. My friends at the Conservatory kept kidding me, "What are you slipping these trumpet players? Are you trying to kill them off so you can play? What's going on?" In view of the fact that two-thirds of the trumpet section experienced health issues in two consecutive years, the management decided to add the fourth trumpet, which was the job I won. I'm sure there were rumors that it was handed to me. Not really. I had to audition for the job just like everybody else.

What was that audition like? Was this before screened auditions?

It was held in the maestro's dressing room, definitely before the days of screened auditions. The room was very crowded. On the committee were the maestro, the associate conductor, the manager of the orchestra, the president of the union, the trumpet section, the principal and second trombone, the tuba, and the concertmaster. There was barely enough space for me in that room. It was pretty intimidating. Auditions can be nerve-wracking, especially one where you know everyone on the panel.

Was this your first major symphony audition? Were you able to audition for any other groups? Yes, that was my first audition. The year before I won my job, maybe two years, there was an opening for second trumpet in the St. Louis Symphony Orchestra. Back in those days, generally what happened was that the personnel manager would call around the country to the different music schools, or the different orchestra principals, to inform them of the vacancy, and ask for recommendations. My teacher, Mr. Blee, got the call. When he recommended me, the personnel manager said, "Thank you very much, but our conductor wouldn't even listen to her, much less hire her, no matter how good she is." Basically, he said, "Don't come."

A few years later Susan Slaughter won the third trumpet position there, obviously under a different conductor. I was so thrilled for her when after a few years in the section, she was moved up to principal trumpet. After I retired from the Cincinnati Symphony, Susan had me come down to play with the orchestra a lot. I did some principal and assistant principal work with them, but mostly second trumpet. During one of my second trumpet rotations, I looked at her and said, "Susan, you know this has been a long time in coming. This is the spot that just about thirty years ago they wouldn't let me audition for, and here I am, playing second trumpet to you." Who knows, maybe we could have been a two-woman section. 
You didn't know her at that time?

No. What happened was that her teacher, I think it was Louis Davidson, encouraged her to start taking auditions. He told her, "Look, there is a gal sitting in the Cincinnati Symphony. If she can do it, you can too."

You had an affect on her and you didn't even know her.

I guess so. With Susan, I knew about her, and she knew about me but we had never met. Not until the first conference. I received a call from Susan inviting me to come and appear at the first IWBC conference. My schedule was horrendous, but I still agreed to do it. I flew in one morning, shared a master class with Barbara Butler and Langston Fitzgerald, attended half of a seminar, ate half a dinner, and flew back to Ohio, all in the same day. I was there for a very brief period, and remembered envying everyone who could be there for the duration. It was such a powerful experience that I didn't want to leave. The energy was through the roof. It was a game changer for me.

So when you left that first conference, what did you take with you? How did it affect you when you went back to your normal routine?

There was such an unmistakable collective energy and camaraderie. It was almost a spiritual experience. Very empowering. In my generation, there were so few women brass players. There I was all of a sudden, surrounded by all these great women brass players. It was just so positive. When we had the second conference in '97, I had already retired from the orchestra, so I was there for the whole thing. That's when I was elected president of the IWBC.

What effect do you think that first conference had on the performance opportunities for brass players and trumpet players specifically?

My perspective on this may be a little limited. I wasn't there to witness the full scope or impact of the conference. I can say that based on what I saw, it was as much of an eye opener for the men as it was for the women. There was a general resolve coming from all areas that yes, these women can do this, and they can do it really well. Based on what I saw, I just had a sense that there would be more of an effort to support women. As a result, I think we were empowered. Actually, it was a feeling of affirmation and empowerment.

Can you tell me about Betty Glover?

She was one of my mentors, my most influential role model, and to this day is one of my dearest friends. I learned so very much from her. I was in her brass orchestral repertoire class at the Conservatory. I learned the orchestra business in the orchestra, and in her class. She was a visionary. Her course in brass orchestral repertoire was one of the first (if not the first) in the country. She was a very dynamic, brilliant woman, a terrific musician and pedagogue. Talk about a pioneer! She was playing trombone in Kansas City in the 1940's, and bass trombone in Cincinnati in the 1950's. Way ahead of any of the rest of us. A truly remarkable accomplishment in a male dominated profession.

Do you consider yourself to be a role model or trailblazer for female trumpet players? Looking back over my career, I guess I really have become a role model ... and maybe even a trailblazer ... particularly since I was the first woman trumpeter in a major symphony orchestra. It really never occurred to me while I was living my dream, that that was what was happening. 
Even so, I do still consider women like Betty Glover, Connie Weldon, Melba Liston, and others more of the trailblazers. They were the ones that made it easier for me to do what I've done. Hopefully, I have continued to forge the path that they started so that the generation of women brass players that comes after me will have an easier time of it. The prospects are brighter than ever. Just look at all the high profile symphony orchestra jobs women have been winning in the past five years. 


\section{Bibliography}

“Aida Quartette.” Iowa Digital Library. http://digital.lib.uiowa.edu. (accessed March 8, 2009).

“The Aida Quartette and Mr. C. Pol Plancon.” Iowa Digital Library. http://digital.lib.uiowa.edu. (accessed March 8, 2009).

"The Aida Quartet of New York City." Iowa Digital Library. http://digital.lib.uiowa.edu. (accessed March 8, 2009).

American Federationist: Official Magazine of the American Federation of Labor 6, no. 10 (December 1899) http://books.google.com. (accessed March 13, 2009).

“American Ladies Grand Concert Band." Redpath Chautauqua Collection. University of Iowa Libraries Special Collections Department. http://sdrcdata.lib.uiowa.edu/libsdrc/details.jsp?id=/amerladies/1. (accessed March 8, 2009).

“American Popular Song Sheet Covers: 1890-1922.” New York Public Library Digital Gallery. http://digitalgallery.nypl.org. (accessed February 10, 2009).

Ammer, Christine. Unsung: a History of Women in American Music, 2d ed. Portland: Amadeus Press, 2001.

Backhaus, Patricia. "An Adamless Garden of Musical Eves: A Short History of Helen May Butler, The Female Sousa and Her American Ladies' Concert Band." Kongressbericht Feldkirch/Vorarlberg 1992 (1994): 181-84.

_ . "Source Guide for Research on Women Instrumentalists, c. 1840-1960." http://www.adagioconcepts.com/cornetpat.html. (accessed March 2, 2009).

"Bandwagon, November-December, 1958." Circus Historical Society. http://www.circushistory.org/Bandwagon/bw-1958Nov.htm. (accessed January 10, 2009).

Berg, Andrew Scott. Lindbergh. New York: The Berkeley Publishing Group, 1998.

"Biographies of the 1993 Honored Pioneers." Newsletter of the International Women's Brass Conference 1, no. 3 (August 1993): 4.

Block, Adrienne Fried and Carol Neuls-Bates, compilers and editors. Women in American Music: A Bibliography of Music and Literature. Westport, CT: Greenwood Press, 1979.

Bowers, Jane, and Judith Tick, editors. Women Making Music: The Western Art Tradition, 11501950. Urbana and Chicago: University of Illinois Press, 1987. 
Bradley, Arthur. On and Off the Bandstand. New York: iUniverse, 2005. http://www.googlebooks.com.

Bridges, Glenn. Pioneers in Brass. CD-ROM. Trescott Research, 2001.

Card, Robyn. "A Life of Firsts: An Interview with Carole Dawn Reinhart." International Trumpet Guild Journal 30, no. 2 (January 2006): 6-13.

"Career Alternatives in Music: Some Advice from Outstanding Women Musicians." The Instrumentalist 31, no. 5 (December 1976): 34-39.

"Carole Dawn Reinhart - Biographical Notes." International Trumpet Guild http://www.trumpetguild.org/news/news03/114areinhartbiog.htm. (accessed 15 March 2009).

"Centuries ago in the Gazette: Salem, 1905." Salem Gazette. 17 November 2005, from Wicked Local Gazette. http://www.wickedlocal.com/salem/archive. (accessed February 13, 2009).

Cooper, Stefan. "The Trumpet Players of the San Francisco Symphony, 1911-1995." International Trumpet Guild Journal 20, no. 3 (February 1996): 32-41.

“Cornetists Knoll \& McNeil.” Western Maryland's Historical Library. http://www.whilbr.org/itemdetail.aspx?idEntry=3628. (accessed February 22, 2009).

"Cupid Plays Havoc in Band: Navassars' Manager is Kept Busy Looking for New Musicians." The Kansas City Journal 100-Year Weblog. http://www.vintagekansascity.com/100yearsago/labels/arts.html. (accessed January 27, 2009).

Dempf, Linda. "All-Women Orchestras in the United States and the Story of the Woman's Symphony Orchestra of Chicago.” D.M.A. diss., Indiana University, 2002.

—_. "The Woman's Symphony Orchestra of Chicago." Notes: Quarterly Journal of the Music Library Association 62, no. 4 (June 2006): 857-901.

Dudgeon, Ralph Thomas. "An Interview with Edna White Chandler." International Trumpet Guild Journal 15, no. 2 (January 1990): 4-10.

Duga, Chief Master Sgt. Jan Z. "Faithful to a Proud Heritage." Air Force Print News Today. August 29, 2008. http://www.bolling.af.mil/news/story_print.asp?id=123112418. (accessed February 19, 2009).

"Edna White Trumpeters.” Iowa Digital Library. http://digital.lib.uiowa.edu. (accessed March 8, 2009).

"The Fadettes Woman's Orchestra of Boston." Redpath Chautauqua Collection, University of Iowa Libraries Special Collections Department. http://sdrcdata.lib.uiowa.edu/libsdrc/details.jsp?id=/fadettes/1. (accessed January 10, 2009). 
Fleet, Susan. "Edna White Chandler: A Brasswoman Pioneer." Women of Note Quarterly 2, no. 4 (November 1994): 7-12.

Forwe, Wilma. "A Woman I Would Like to Know: Browne Greaton Cole." Ocala Outlook 7, no. 11 (May 2008): 5.

Franklin County News Archive. "Archive Article: Stunt Performers." http://www.publicationarchive.com/archiveArticle.cfm?g=184\&cs=230\&num=400. (accessed January 13, 2009).

"Gift Shop Postcards." National Music Museum. http://www.usd.edu/smm/GiftShop/PostcardsBW/LillianSieger.html. (accessed January 13, 2009).

Goldin, Claudia and Cecilia Rouse. "Orchestrating Impartiality: The Impact of 'Blind' Auditions on Female Musicians." The American Economic Review 90, no.4 (September 2000): 715-41.

"Grace Adams East." Redpath Chautauqua Collection. University of Iowa Libraries Special Collections Department. http://sdrcdata.lib.uiowa.edu/libsdrc/details.jsp?id=/east/1. (accessed February 8, 2009).

Graffam, Allen. "R. B. Hall Marches."

http://www.mta75.org/curriculum/music/rbh/marchlist.html. (accessed January 30, 2009).

Grant, Margaret and Herman S. Hettinger. America's Symphony Orchestras and How They are Supported. New York: Norton and Company, 1940.

Gustafson, Karen. "Marie Speziale: Performer, Teacher and Pioneer." International Trumpet Guild Journal 26, no. 4 (June 2002): 7-14.

"Helen May Butler." http://www.wbutler.com/link/Biographies/Butler/HelenMayButler/Index.html. (accessed February 8, 2009).

Handy, D. Antoinette. "Black Women and American Symphony Orchestras." The Maud Powell Signature 1, no. 3 (Winter 1996): 21-25.

_ Black Women in American Bands and Orchestras. 2d ed. Lanham, MD: Scarecrow, 1998.

Hazen, Margaret Hindle and Robert M. Hazen. The Music Men: An Illustrated History of Brass Bands in America, 1800-1920. Washington, D.C.: Smithsonian Institution Press, 1987.

Hersey, Joanna Ross. “'Such Unfeminine Instruments': Women Brass Musicians in America Before 1940.” D.M.A. diss., University of Hartford, 2006. 
International Trumpet Guild. Cornet Solos by Pioneer American Recording Artists Made prior to 1906. Seth B. Winner Sound Studios. CD ITG-004, 1994.

Jenkins, Eloise M. "Women as Professional Horn Players in the United States, 1900-2005." D.M.A. diss., University of Wisconsin-Madison, 2005.

"Jim Crow Press: Indiana." http://www.jimcrowhistory.org/scripts/jimcrow/press.cgi?state=Indiana. (accessed January 4, 2009).

Kerbey, Therese. " $14^{\text {th }}$ Army Band WAC, 1942-1976." The University of Arizona. http://www.public.asu.edu/ tmontgom/. (accessed February 22, 2009).

Lee County Iowa GenWeb Project. "Articles from Montrose, Iowa Journal, 10 February 1910." transcr. by Connie (Dobson) Putthoff. http://iagenweb.org/lee/montjourn/1910.htm. (accessed January 12, 2009).

Leach, Cathy. "The International Women's Brass Conference: Personal Reflections." International League of Women Composers Journal (October 1993): 34.

“Leona May Smith, 1914-1999." International Women's Brass Conference Newsletter 4, no. 9 (Winter 1999): 1.

Lloyd, June. "York Berger Family Makes it Big." York’s Historical Connection, 4 January 2009. http://www.yorkblog.com/universal/2009/01/york-berger-family-musicians-m.html\#more. (accessed January 18, 2009).

Macleod, Beth Abelson. "“Whence Comes the Lady Tympanist?' Gender and Instrumental Musicians in America, 1853-1990.” Journal of Social History 27, no. 2 (Winter 1993): 291308.

. "Whence comes the Lady Tympanist?: Women and Musical Instruments in America." The Maud Powell Signature 1, no. 3 (Winter 1996): 5-8, 26-8.

- Women Performing Music: The Emergence of American Women as Classical Instrumentalists and Conductors. Jefferson, NC: McFarland, 2001.

Maloof, Lisa. "Focus Story: Women in Brass." The Women's Philharmonic Newsletter (Spring 1998): 9.

"Marie Speziale: Professor of Trumpet, and Chair, Brass." The Shepherd School of Music, Rice University. http://music.rice.edu/facultybios/speziale.html. (accessed March 2, 2009). 
“Martha Awkerman WAF and Long Beach Band Papers, 1940-2002." University of Illinois Archives.

http://www.library.uiuc.edu/archives/archon/index.php?p=collections/controlcard\&id=3133. (accessed March 8, 2009).

Miller, Betsy G. “Anna Teresa Berger, Cornet Virtuoso." International Trumpet Guild Journal 22, no. 3 (February 1998): 43-9.

"Musical Notes and News." The Musical Visitor, a Magazine of Musical Literature and Music, 1883-1897 19, no. 4 (April 1890): 90.

Myers, Douglas W. and Claire Etaugh. "Women Brass Musicians in Major Symphony Orchestras: How Level is the "Playing" Field?" International Alliance for Women in Music Journal 7, no. 3 (2001): 28-31.

Neuls-Bates, Carol. Women in Music. Boston: Northeastern University Press, 1996.

- editor. Women in Music: An Anthology of Source Readings from the Middle Ages to the Present. New York: Harper \& Row, 1982.

_ Western Art Tradition, 1150-1950, edited by Jane Bowers and Judith Tick. Urbana and Chicago: University of Illinois Press, 1987. 349-369.

Nichols, Jeananne. "The United States Air Force Women's Band (WAF), 1951-1961.” The University of Arizona. http://www.public.asu.edu/ jmsulli/WAF_NICHOLS.htm. (accessed February 21, 2009).

Osborne, William. "Women in Major Orchestras: An Update." International Alliance for Women in Music Journal 7, no. 3 (2001): 31.

Ossi, John. "Trumpet Personnel in Major North American Orchestras: 1989." International Trumpet Guild Journal 14, no. 1 (September 1989): 71-73.

Pendle, Karin. Women in Music: A Research and Information Guide. New York: Rutledge, 2005.

"Picture History: The Primary Source for History Online." http://www.picturehistory.com/product/id/23558.html. (accessed December 28, 2008).

"Pittsburgh Ladies Orchestra: A Company of High Class Entertainers - Vocal and Instrumental." Redpath Chautauqua Collection. University of Iowa Libraries Special Collections Department. http://sdrcdata.lib.uiowa.edu/libsdrc/details.jsp?id=/pittsburgh1/1. (accessed February 2, 2009).

Pokorny, Gene. “Interview with Susan Slaughter." International Women's Brass Conference Newsletter 1, no. 1 (June 1992): 2-3. 
Rehrig, William H. The Heritage Encyclopedia of Band Music: Composers and their Music. ed. Paul E. Bierley, vol. 3. Westerville, Ohio: Integrity Press, 1991.

Roesch, Clara Burling. "The Plight of the Woman Symphony Player." Music Clubs Magazine 31, no. 4 (March 1952): 5, 36.

Schwartz, Richard I. "The African American Contribution to the Cornet of the Nineteenth Century: Some Long-Lost Names.” Historic Brass Society Journal 12 (2000): 61-75.

— . "The Cornet Compendium: The History and Development of the Nineteenth-Century Cornet." http://www.angelfire.com/music2/thecornetcompendium/. (accessed March 4, 2009).

Seltzer, Frank R. "Famous Bandmasters in Brief: No. 58 - Ernest S. Williams." Jacobs Band Monthly (August 1923): 16-7, In Keith Winking, "The Legacy of Ernest S. Williams." International Trumpet Guild Journal 24, no. 2 (January 2000): 34-53.

Skowronski, JoAnn. Women in American Music: a Bibliography. Metuchen, NJ: Scarecrow Press, 1978.

Slaughter, Susan. "The IWBC at 10 Years: A Look Back." International Women's Brass Conference Newsletter 9, no. 2 (Winter 2003): 6-7.

"Saint Louis Symphony Orchestra's Principal Trumpet Susan Slaughter." Woodwind WorldBrass and Percussion 15, no. 1 (1976): 36.

Smith, Leona May. "Is there a Career for Women Musicians?" Metronome 54, no. 1 (January 1938): 48.

Stolfus, Mary L. "Eve in the Ensemble" Musical Courier 136, no. 8 (December 1947): 9, 17.

Sullivan, Jill M. “A Century of Women's Bands in America." Music Educator's Journal 95, no. 1 (Sep 2008): 33-40.

- "A History of the Marine Corps Women's Reserve Band." Journal of Band Research 42, no. 1 (Spring 2001): 1-42.

_. "Women's Army Corps Bands." The University of Arizona. http://www.public.asu.edu/ jmsulli/Webpages/wac.html. (accessed February 21, 2009).

. "Women's Military Bands in a Segregated Army: The $400^{\text {th }}$ and $404^{\text {th }}$ WAC Bands." Journal of Band Research 41, no. 2 (2006): 1-35.

Telephone Review. New York: The New York Telephone Company, 1915. 
Tick, Judith. "Women as Professional Musicians in the United States,1870-1900." Yearbook for Inter-American Musical Research, International 9 (1973): 95-133.

Tucker, Sherrie. "Susan Slaughter." Windplayer, for Woodwind and Brass Musicians 10, no. 3 (1993): 24-29.

. Swing Shift: All-Girl Bands of the 1940s. Durham and London: Duke University Press, 2000 .

Winking, Keith Robert. "Ernest Williams, Virtuoso and Educator: A Biographical Survey of his Philosophies and Techniques." D.M.A. thesis, The University of Texas at Austin, 1993.

"Women Brass Musicians: Past and Present, Professionals in Performance and University Education.” St. Louis: International Women’s Brass Conference, 1993. 


\title{
Curriculum Vitae
}

\author{
Robyn Dewey Card \\ Suffolk, Virginia
}

\section{Education:}

Doctor of Musical Arts: Trumpet Performance (May, 2009)

West Virginia University, Morgantown, WV

Coursework in Supervision of Instruction (Spring, 1998)

Marshall University Graduate College, Huntington, WV

Master of Science in Music Education, Brass Studies (1992-1994)

University of Illinois, Champaign-Urbana, IL

Bachelor of Music Education, Instrumental Concentration (1982 - 1987)

James Madison University, Harrisonburg, VA

\section{Previous Professional Experience: Post Masters Degree}

Academic:

Visiting Assistant Professor, Elizabeth City State University, Elizabeth City, North

Carolina (August, 2005-May 2006)

Coordinator, Music Industry Studies Program

Taught Music Business Courses:

Introduction to Music Industry Studies (MUS $117-3$ credits)

Music Salesmanship (MUS $415-3$ credits)

Music Marketing (MUS $418-3$ credits)

Music Seminar I and II (MUS 431 - 3 credits; MUS 432 - 3 credits)

History of American Popular Music (MUS $304-2$ credits)

Supervised Music Industry Internships (MUS 417 - 6 credits)

Fall, 2005 - student placed with WRVS-FM 89.9 \& W18BB ECSU TV

Spring, 2006 - student placed with Black Entertainment Television and accepted into the UNC Semester-in-Washington Program

Director, Collegians Jazz Ensemble (MUS 240 - 1 credit)

Instruct High Brass Students (MUS 062, 362, 090, 390 - 1 or 2 credits per student) :

Fall, 2005 - 4 students; Spring, 2006 - 5 students

Teach Music Education Course:

Brasswinds (MUS $245-2$ credits)

Served as Music Department Liaison on the College of Arts \& Humanities Spring Arts Festival Committee

Contracted guest artist Joel L. Joyner to appear with the Collegians Jazz Ensemble.

Contracted the Virginia Arts Festival Rhythm Project (a world-music group) to appear as the headliner group for the Friday outdoor event held at Waterfront Park in downtown Elizabeth City.

Coordinated with graphics design professor to create uniform playbills and advertising materials to be used for each event. 
Reserve Component Instrumental Instructor, Armed Forces School of Music, Norfolk, Virginia (Summers, 2005-2006)

Teach high brass (trumpet/horn) in this groundbreaking program of instruction where civilians are contracted to provide military specialist training.

Music Instructor, Young Musicians of Virginia, Virginia Beach, Virginia (September, 2002May 2005)

Instruct students in individual lessons on brass instruments.

Teach music theory (intermediate and advanced levels).

Conduct Brass Ensemble.

Lecturer in Music, Department of Music, Christopher Newport University, Newport News, Virginia (August-December, 2003)

Taught Brass Instrument Techniques (MUSC220-01) One semester, 24 students.

Lecturer in Music, Department of Music, Fairmont State College, Fairmont, West Virginia (July, 2002)

Taught Elementary Music II (MUS 232-Section 001) One semester, 33 students.

Instructor, School of Music, West Virginia University, Morgantown, West Virginia (August 2000-June 2002)

Supervised Music Student Teachers (MUSC 492L) Four semesters, 3-9 students per semester teaching general, vocal, and instrumental music grades K-12.

Taught Instrumental Pedagogy/Brass (MUSC 281-Section 02) Two semesters, 14 students per semester.

Supervised the Laboratory Band Instrumental Methods (MUSC 380-Section 01), Two semesters, 60 students per semester. Evaluated and coached the teaching methodology used by the 9-12 students registered for the Methods course. Supervised the remaining 40-60 students in their study and performance of secondary instruments.

Coached an undergraduate brass quintet.

Taught non-major trumpet students.

Lecturer in Music, West Virginia Wesleyan College, Buckhannon, West Virginia (August, 2000-June, 2002)

Taught Trumpet Studio (MUS 155) Four semesters, music majors and non-majors, 6 students per semester.

Conducted Trumpet Ensemble ( MUS 149) 4 students per semester.

Brass Clinician/Studio Teacher, Charleston, West Virginia (August, 1994-August, 2000)

Recruited and maintained a private studio of 25 students, grades 6 through college, beginning to advanced levels. Conducted sectionals and master classes in the Charleston and surrounding area schools, grades 6-12. 


\author{
Performance: \\ Virginia Beach Symphony Orchestra, Virginia Beach, VA (July 2004-present) \\ Protocol Brass, Norfolk, VA (2003-present) \\ Tidewater Winds, Norfolk, VA (2002-present) \\ Virginia Wind Symphony, Norfolk, VA (2002-present) \\ ECSU/Albemarle Symphony Orchestra, Elizabeth City, NC (Fall, 2005 - Spring, 2006) \\ Eastern Virginia Brass Quintet, Norfolk, VA (December, 2003) \\ Appalachian Brass Quintet, Buckhannon, WV (1996-2002 \\ West Virginia Symphony Orchestra, Charleston, WV (1994-2002) \\ Burnished Brass, Charleston, WV (1995-2002) \\ Lipzz Big Band, Charleston, WV (1997-2002) \\ The Brass Society, Charleston, WV (1995-2000) \\ Mel Gillispie Orchestra, Huntington, WV (1994-2000) \\ Huntington Outdoor Theatre, Huntington, WV (1997-1999) \\ Brass Band of the Tri-State, Ashland, KY (1995-1997) \\ Ohio Valley Symphony, Gallipolis, OH (1994-1996)

\section{Publication:}

A Life of Firsts: An Interview with Carole Dawn Reinhart, International Trumpet Guild Journal. Lead article in the January, 2006 issue.

\title{
Previous Professional Experience: Post Baccalaureate Degree
}

\section{Academic:}

Graduate Teaching Assistant, School of Music, University of Illinois, Urbana, Illinois (Aug, 1993-Aug, 1994)

Taught undergraduate courses in trumpet teaching methods. Assisted Dr. Michael Ewald (trumpet professor) in coordinating the 1994 International Trumpet Guild Conference which was held at the University of Illinois.

Director of Bands, Highland Belle Middle School, Lexington, Virginia (August, 1987-June, 1992)

Instructed students grades six through eight in instrumental music through regularly performing ensembles. Coordinated all administrative responsibilities including scheduling, fundraising, and bookkeeping. Built the band program from 18 to 130 members in five years.

Elementary Music Teacher, Fairfield Elementary School, Fairfield, Virginia (August, 1989June, 1992)

Organized and instructed an elementary music program for 200 students, kindergarten through third grade.

Band/Choir Director, Lexington High School, Lexington, Virginia (August, 1987-June, 1989)

Taught instrumental and choral ensemble grades nine through twelve. This included marching, concert and jazz bands as well as show choir. Supervised all fundraising of booster club and school music accounts. 


\author{
Performance: \\ Mark Fouch Brass Band, Champaign, IL, (1994) \\ Crystal Lake Brass Quintet, Champaign, IL (1993-94) \\ The University of Illinois Symphonic Band, Champaign, IL (1993-94) \\ The University of Illinois British Brass Band, Champaign, IL (1992-94) \\ The University of Illinois Opera Pit Orchestra, Champaign, IL (1994) \\ Al Winter's Sugar \& Spice Big Band, Staunton, VA (1989-92) \\ Stonewall Brigade Band, Staunton, VA (1987-92) \\ Stonewall Brigade Big Band, Staunton, VA (1987-92) \\ General Electric Big Band, Charlottesville, VA (1991) \\ Rockbridge Orchestra, Lexington, VA (1987-1990) \\ Washington \& Lee Wind Ensemble, Lexington, VA (1988-89)
}

\title{
Related Professional Experience:
}

Young Musicians of Virginia Board of Directors, Virginia Beach, VA (August, 2007-present) Chairman of Board since October, 2008: Governing body of this organization that provides musical experience opportunities for school-aged children who are home schooled.

Organization provides academic and music classes as well as ensembles (band, choir, jazz band, hand bells, orchestra, chamber ensembles, etc).

Operations and Finance Assistant, Virginia Arts Festival, Norfolk, VA (February, 20032005): Assist the Operations Director in coordinating air travel, lodging, scheduling/itineraries, catering, ground transportation, volunteers, and other items directly related to meeting the contractual obligations of each artist participating in the Festival. Compile information for and proofread copy for playbills. Event management. Assist the Finance Director with Accounts Payable, Payroll, and Accounts Receivable.

International Women's Brass Conference Pioneer Committee, St. Louis, MO (January, 19992003): Chair of Committee responsible for documenting the history of women brass players in order to celebrate their achievements and stimulate further research. Interview brass artists who are being honored for their work in the areas of performance and education. Presented two Pioneer Award recipients at the Pioneer Awards Banquet held at Washington University in June of 1997.

West Virginia Festival of Trumpets Recital Series, Charleston, WV(April, 1996-2002): Founder and organizer of this festival which featured trumpet players of all levels in solo, chamber, and large group performances. The purpose of this festival was to provide a performing venue for trumpeters of all levels. Guest clinicians that appeared at the festival included Colonel John Brodie (Virginia Military Institute), Terry Everson (University of Kentucky), Vincent DiMartino (Centre College), James Kluesner (James Madison University), John Schlabach (Ohio University) and Victor Rislow (Susquehanna University). 
West Virginia Music Educators National Conference, Morgantown, WV (March, 2001): Presenter at clinic Inside Student Teaching: Tales from the Field.

Cabell County Middle School Band, Huntington, WV (March, 2001): Guest conductor for the all-county band.

Simple Gifts, (February, 2001) and The Rejoicing, (June 2002): Produced and recorded compact discs for the Appalachian Brass Quintet.

Kerr's Music World, Charleston, WV (1995-2000) - Music support specialist. Duties included purchasing all music and supplies for sales, finalizing music instrument rental contracts, establishing and maintaining working relationships with music vendors (including publishing companies and instrument suppliers) and music teachers.

Glenville State College Summer Brass Workshop, Glenville, WV (June, 2000): Coached mixed brass ensembles and trumpet ensemble in week-long workshop. Taught special sessions on jazz improvisation.

West Virginia Youth Symphony, Charleston, WV (Summer, 2000): Brass coach.

Skidmore Jazz Institute, Saratoga Springs, NY (July, 1999): Attended the two week jazz workshop which included special courses in jazz improvisation, theory, history and combo performance. Teachers included John LaBarbera, Vince DiMartino, Curtis Fuller, Todd Coolman and other jazz masters.

Glenville State College Brass Workshop, Glenville, WV (January, 1998): Presented a trumpet master class to high school and college level brass students participating in this workshop. Conducted the trumpet ensemble in rehearsals and a performance given for the public.

West Virginia Trumpet Ensemble, Charleston, WV (1997-1998): Founder of this organization of performers/educators from throughout the state of West Virginia. This group commissioned and premiered the composition Flicker at the 1998 West Virginia Music Educators Conference in Morgantown, WV and 1998 International Trumpet Guild Festival of Trumpets Concert.

1994 International Trumpet Guild Conference, Urbana, IL (August, 1993-August, 1994): Assisted in coordinating the conference which was held at the University of Illinois. Duties included organizing committees of workers for stage crew, artist transportation, exhibits, and registration.

Virginia Band \& Orchestra Director's Association (VBODA) Secretary for District V, Staunton, VA (1989-92): Responsible for recording the minutes and mailing them to participating directors in the district. Monitored accounting for VBODA District V events including those listed below. 
VBODA District V Band Event, Charlottesville, VA (1992): Host for the high school and middle school students performing in three separate bands during the District Band weekend.

VBODA District V Solo \& Ensemble Festival, Lexington, VA (1988, 1991): Host to 125 high school and middle school students performing solos and chamber music for ratings.

Central Highlands Area Band Lexington, VA (1989-92): Founder and host for the auditions and event which provided students an opportunity to participate in a large wind ensemble conducted by a guest artist.

Major Instructors

John Winkler - West Virginia University, Morgantown, WV

Ray Sasaki - University of Illinois, Urbana, IL

Michael Ewald - University of Illinois, Urbana, IL

James Kluesner - James Madison University, Harrisonburg, VA

Additional Study and/or master classes with:

Stephen Carlson - Virginia Symphony, Virginia Beach, Virginia (Summer, 1986)

Carole Dawn Reinhart - Vienna, Austria

Keith Jackson - West Virginia University, Morgantown, WV

Curtis Johnson - West Virginia University, Morgantown, WV

Terry Everson - University of Kentucky, Lexington, KY

Vince DiMartino - Centre College, Danville, KY

Laurie Frink - New York, NY 